\title{
Evaluation of Neutron Absorbers in the DOE Standardized SNF Canister
}

\author{
Gordon Petersen
}

September 2019

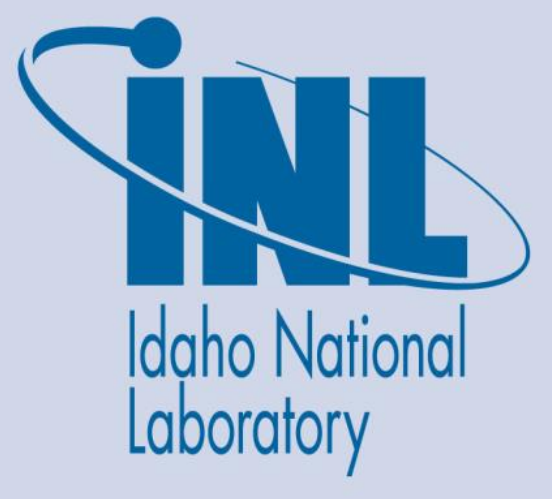

The INL is a U.S. Department of Energy National Laboratory operated by Battelle Energy Alliance 


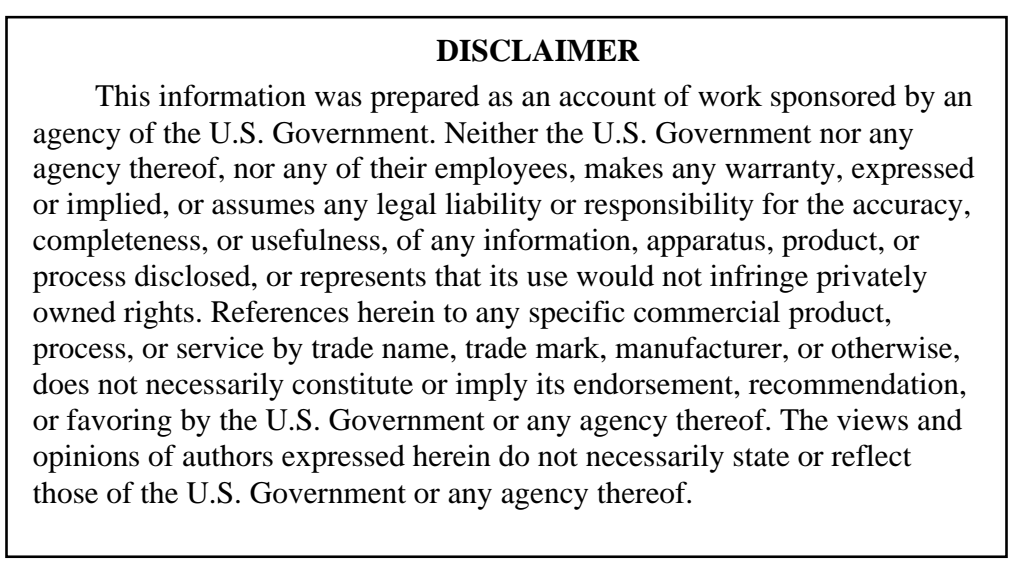

\section{DISCLAIMER}

This research made use of the resources of the High-

Performance Computing Center at Idaho National Laboratory, which is supported by the Office of Nuclear Energy of the U.S. Department of Energy and the Nuclear Science User Facilities under Contract No. DEAC07-05ID14517. 


\section{REVISION HISTORY}

Rev. 0: Initial Issue

Rev. 1: Incorporated DOE Comments 
INL/EXT-19-53193

Revision 1

\title{
Evaluation of Neutron Absorbers in the DOE Standardized SNF Canister
}

\author{
Gordon Petersen
}

September 2019

Idaho National Laboratory Idaho Falls, Idaho 83415

http://www.inl.gov

\author{
Prepared for the \\ U.S. Department of Energy \\ Office of Nuclear Energy \\ Under DOE Idaho Operations Office \\ Contract DE-AC07-05ID14517
}




\section{SUMMARY}

The goal of this evaluation was to evaluate different options for a neutron absorber in the U.S. Department of Energy (DOE) Standardized spent nuclear fuel (SNF) Canister. This was accomplished by taking the two most relevant criticality evaluations and replacing the advanced neutron absorber (ANA) basket material with borated stainless steel.

This work was initiated, because alternative storage options for DOE SNF has become a priority for DOE. Idaho National Laboratory (INL) is initiating activities to ensure the continued operation of the Advanced Test Reactor (ATR) by providing alternative and redundant storage options for spent ATR fuel. In addition, the DOE Office of Environmental Management (EM) has recently initiated studies to understand and improve the technical basis for long-term dry storage of aluminum clad SNF (e.g., ATR, High Flux Isotope Reactor [HFIR]) (Connolly 2018). While currently in the lab-scale phase, the next step involves validation and verification $(\mathrm{V} \& \mathrm{~V})$ of the lab-scale results. One method to perform $\mathrm{V} \& \mathrm{~V}$ is to load aluminum-clad spent fuel in an instrumented DOE Standardized SNF Canister as a demonstration. In order to minimize the need for repackaging before disposal and to provide a representative environment in a demonstration, the fuel is planned to be loaded with an appropriate criticality control mechanism, such as neutron absorbing basket material. While ANA was originally selected as the basket material for ATR fuel in the Yucca Mountain Repository, it has never been produced on a large scale. Therefore, incorporating this material in the DOE Standardized SNF Canister as part of a near-term demonstration could be more challenging than moving forward with a commercially available material, such as borated stainless steel.

Past evaluations eliminated borated stainless steel as a long-term neutron absorbing material, because it corroded too quickly and may not always remain in the waste package after degradation. This led to the invention and selection of ANA for use as the basket material in the DOE Standardized SNF Canister. After selecting ANA, new corrosion tests were performed on borated stainless steel using a different method for fabrication. This method of fabrication significantly improved the corrosion resistance properties of borated stainless steel, so much so that it out-performed ANA in corrosion testing. Researchers used the information obtained from these tests to select borated stainless steel as the neutron absorber in the Transportation, Aging, and Disposal Canister (TAD) designed for commercial SNF.

This evaluation compares the criticality control of borated stainless steel to ANA. In every case and scenario, the calculated effective neutron multiplication factor (k_eff) using a borated stainless steel basket was lower than that using an ANA basket, though the borated stainless steel must be thicker due to corrosion effects over the regulatory time period. Although the borated stainless steel performed better than the ANA, it still required additional neutron-absorbing material, gadolinium shot, for the calculated k_eff to fall below the upper critical limit of 0.93 in a few cases evaluated. More research using thicker baskets or inserts could be performed in an attempt to lower the k_eff without the use of gadolinium shot. In addition, a reevaluation of the degraded ATR material used in the previous evaluations may prove that the original assumptions were over-conservative. 


\section{CONTENTS}

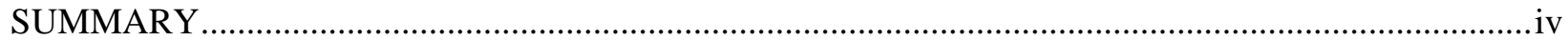

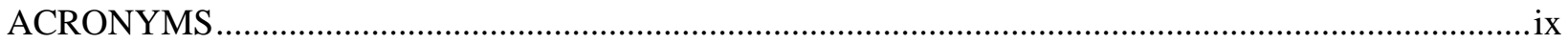

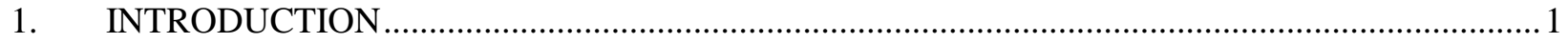

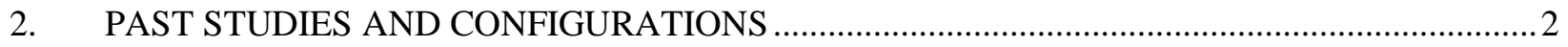

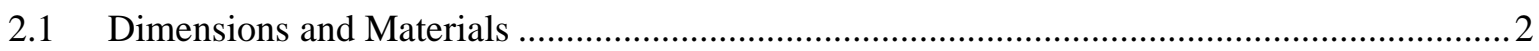

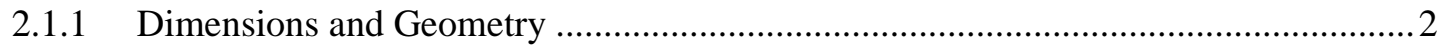

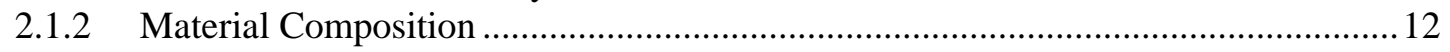

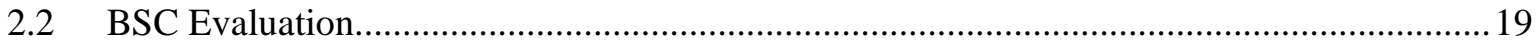

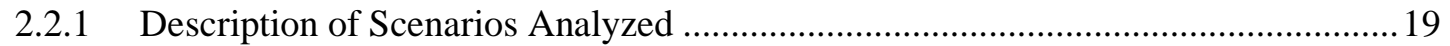

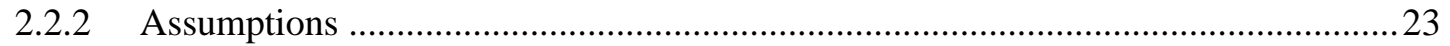

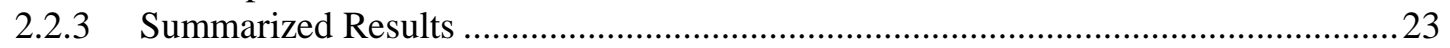

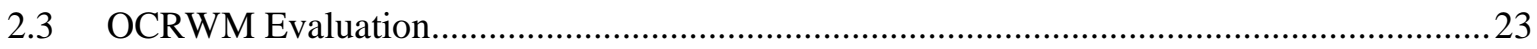

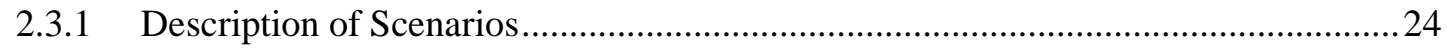

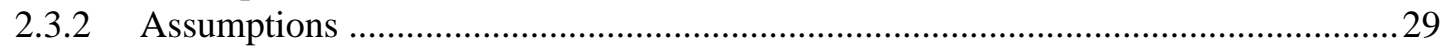

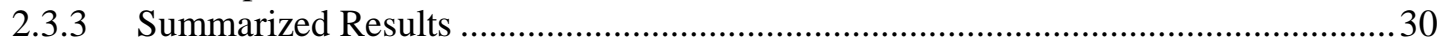

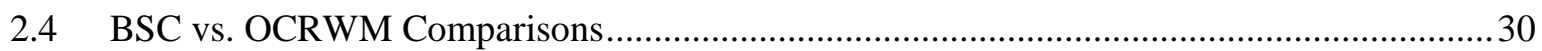

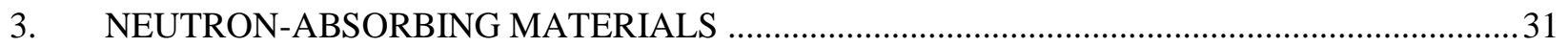

$3.1 \quad$ Ni-Cr-Mo-Gd Alloy ................................................................................................ 31

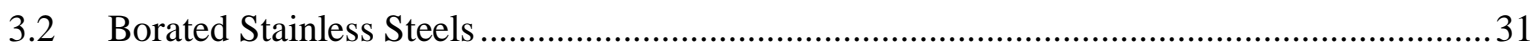

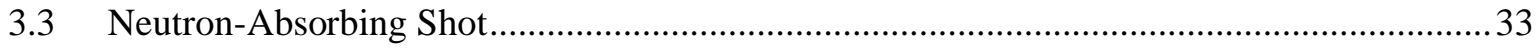

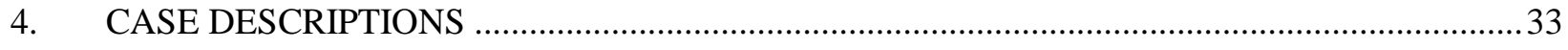

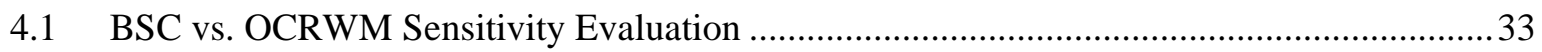

4.2 Comparing ANA and Borated Stainless Steel in BSC's Evaluation ....................................36

4.3 Comparing ANA and Borated Stainless Steel in OCRWM's Evaluation ..............................39

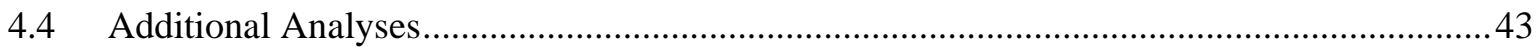

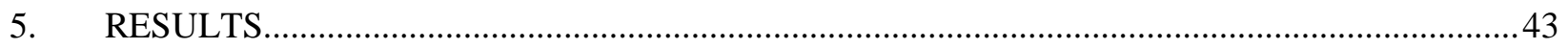

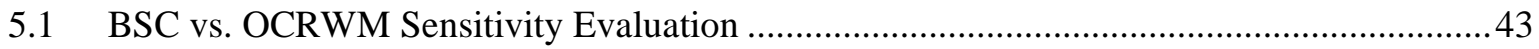

5.2 Comparing ANA and Borated Stainless Steel in BSC's Evaluation ...................................45

5.3 Comparing ANA and Borated Stainless Steel in OCRWM's evaluation..............................47

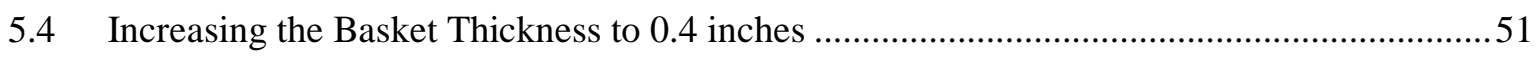

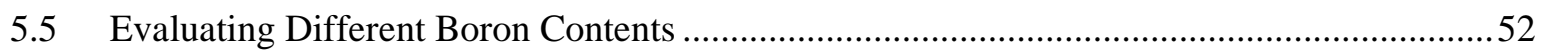

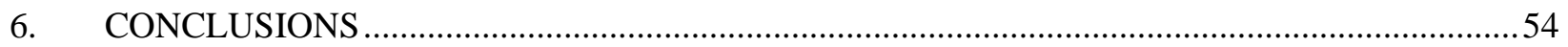

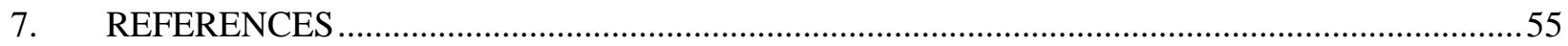




\section{FIGURES}

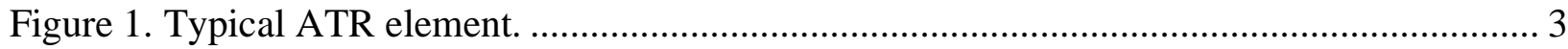

Figure 2. Drawing of the 10-foot DOE Standardized SNF Canister. ...................................... 6

Figure 3. DOE Standardized SNF Canister and Type 1A basket. .......................................... 7

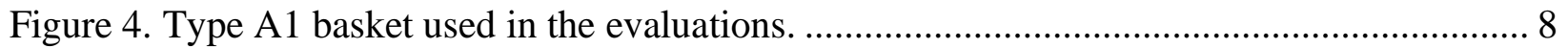

Figure 5. DHLW glass pour canister (BSC 2004) …..................................................... 9

Figure 6. Cross section of the DHLW/DOE SNF codisposal waste package............................ 10

Figure 7. Intact ATR fuel rotated to its most reactive configuration..................................... 20

Figure 8. Intact ATR fuel surrounded by pre-breach clay ................................................ 21

Figure 9. Degraded ATR fuel surrounded by pre-breach clay.............................................. 22

Figure 10. Intact ATR fuel surrounded by an intact DOE Standardized SNF Canister and

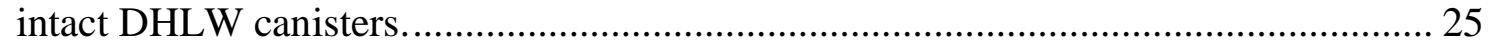

Figure 11. Degraded ATR fuel surrounded by intact DHLW canisters. .................................. 26

Figure 12. Degraded ATR fuel in an intact DOE Standardized SNF Canister surrounded

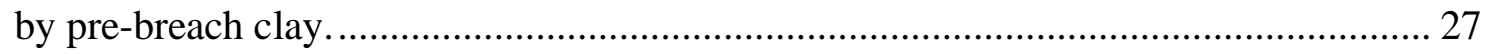

Figure 13. Completely degraded waste package internals with the degraded DOE Standardized SNF Canister and its internals on the bottom, clay in the middle, and water on top.

Figure 14. Degraded fuel in an intact DOE Standardized SNF Canister surrounded by pre-breach clay.

Figure 15. Degraded fuel in an intact DOE Standardized SNF Canister surrounded by intact DHLW canisters.

Figure 16. Intact ATR fuel in a codisposal waste package.................................................... 37

Figure 17. Degraded ATR fuel surrounded by pre-breach clay............................................. 38

Figure 18. Intact ATR fuel in a codisposal waste package ............................................... 40

Figure 19. Degraded ATR fuel surrounded by intact DHLW canisters in a codisposal waste package.

Figure 20. Degraded ATR fuel surrounded by pre-breach clay....

Figure 21. The image on the left represents degraded fuel in a DOE Standardized SNF Canister with a void fraction of 0.3 completely filled with water from the BSC evaluation. The image on the right represents degraded fuel in a DOE Standardized SNF Canister with a void fraction of 0.3 completely filled with water from the OCRWM evaluation. 


\section{TABLES}

Table 1. Comparison of inner radius and 235U content between BSC and OCRWM.................. 4

Table 2. Comparison of plate arc length and fuel meat arc length between BSC and

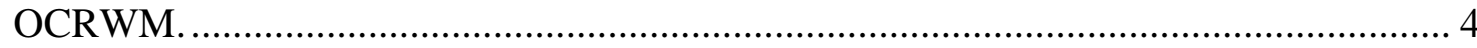

Table 3. Comparison of materials and dimensions for the DOE Standardized SNF Canister. The BSC and OCRWM evaluation use the same dimensions for the DOE Standardized SNF Canister.

Table 4. Comparison of materials and dimensions used for canister internals in the BSC and OCRWM analyses

Table 5. Comparison of materials and dimensions used for the DHLW canister in the BSC and OCRWM analyses.

Table 6. Comparison of materials and dimensions used for the codisposal waste package in the BSC and OCRWM analyses.

Table 7. Comparison of material composition of stainless steel 304L for the BSC and OCRWM. Stainless steel 304L has the same composition in both analyses.

Table 8. Comparison of material composition of stainless steel 316L for the BSC and OCRWM analyses. stainless steel 316L has the same composition in both analyses.

Table 9. Comparison of material composition of stainless steel 316 for the BSC and OCRWM analyses. BSC did not use stainless steel 316 in its evaluation.

Table 10. Comparison of material composition of alloy 22 for the BSC and OCRWM analyses. Alloy 22 has the same composition in both analyses.

Table 11. Comparison of material composition of carbon steel A516 Grade 70 for the BSC and OCRWM analyses.

Table 12. Comparison of material composition of aluminum cladding/aluminum 6061 for the BSC and OCRWM analyses.

Table 13. Comparison of material composition of SRS DHLW Glass for the BSC and OCRWM analyses. SRS DHLW glass has the same composition in both analyses.

Table 14. Comparison of material composition of pre-breach clay for the $\operatorname{BSC}(53,241$ years) and OCRWM (15,072 years) analyses.

Table 15. Comparison of material composition of post-breach clay (20,400 years) for OCRWM analyses. The BSC analysis did not use post-breach clay.

Table 16. Comparison of material composition of Dry Tuff for the BSC and OCRWM analyses.

Table 18. Material composition of borated stainless steels 304B4, 304B5, and 304B6 19

Table 19. Boron compositions for 304B4, 304B5, and 304B6 used in this analysis. 32

Table 20. Comparison of corrosion rates of borated stainless steel. 32 
Table 21. Comparing differences in the BSC evaluation with degraded ATR fuel having a $30 \%$ void fraction in an intact DOE Standardized SNF Canister surrounded by prebreach clay positioned at the bottom of the waste package and the OCRWM evaluation with degraded ATR fuel having a $30 \%$ void fraction in an intact DOE Standardized Canister surrounded by prebreach clay positioned at the center of five DHLW canisters in the waste package. .

Table 23. Calculated results for intact scenarios replacing ANA with 304B4.

Table 24. Results for configurations with complete degradation of ATR SNF inside DOE Standardized SNF Canister with DHLW canister intact.

Table 25. Results for configuration with complete degradation of ATR SNF inside DOE Standardized SNF Canister with DHLW canister intact with additional neutron absorbing shot......

Table 26. Results for varying the basket thickness for degraded DOE Standardized SNF Canister and degraded fuel surrounded by intact DHLW canisters. 51

Table 27. Results for replacing the 304B4 with 304B5 and 304B6. 52

Table 28. Corrosion rates for 304B4 and 304B5. 54 


\section{ACRONYMS}

$\begin{array}{ll}\text { ANA } & \text { Advanced Neutron Absorber } \\ \text { ASME } & \text { American Society of Mechanical Engineers } \\ \text { ASTM } & \text { American Society for Testing and Materials } \\ \text { ATR } & \text { Advanced Test Reactor } \\ \text { BOL } & \text { beginning of life } \\ \text { BSS } & \text { borated stainless steel } \\ \text { DOE } & \text { U. S. Department of Energy } \\ \text { DHLW } & \text { U. S. Department of Energy high-level waste } \\ \text { DWPF } & \text { Defense Waste Processing Facility } \\ \text { EM } & \text { DOE Office of Environmental Management } \\ \text { HFIR } & \text { High Flux Isotope Reactor } \\ \text { INL } & \text { Idaho National Laboratory } \\ \text { MCNP } & \text { Monte Carlo N-Particle Transport Code } \\ \text { MIT } & \text { Massachusetts Institute of Technology } \\ \text { MURR } & \text { Missouri Research Reactor } \\ \text { NSNFP } & \text { National Spent Nuclear Fuel Program } \\ \text { ORCWM } & \text { Office of Civilian Radioactive Waste Management } \\ \text { ORR } & \text { Oak Ridge Research Reactor } \\ \text { SNF } & \text { spent nuclear fuel } \\ \text { SRS } & \text { Savannah River Site } \\ \text { SSCs } & \text { systems, structures, and components } \\ \text { TAD } & \text { Transportation, Aging, and Disposal Canister } \\ \text { V\&V } & \text { validation and verification } \\ \end{array}$




\section{Evaluation of Neutron Absorbers in the DOE Standardized SNF Canister}

\section{INTRODUCTION}

The U.S. Department of Energy (DOE) has responsibility for a great variety of spent nuclear fuel (SNF), which it must safely store, transport, and dispose of. These fuels come from a wide range of reactor types, such as light- and heavy-water-moderated reactors, graphite-moderated reactors, and breeder reactors, with various cladding materials and enrichments. Many of these reactors, now decommissioned, had unique design features, such as core configuration, fuel element and assembly geometry, moderator and coolant materials, operational characteristics, and neutron spatial and spectral properties. This has resulted in a large diversity of reactor and fuel designs. Due to the challenges associated with the diversity of fuels and the lack of qualified information for many types of DOE SNF, it was considered necessary to pursue a safety strategy for licensing that did not rely on the fuel and cladding properties, but on engineered systems, structures, and components (SSCs) and natural barriers. The strategy for ensuring safe long-term management and disposition of DOE SNF required a robust canister that can be relied upon to confine radionuclides and preclude moderator. The strategy decoupled the safety case from the form and condition of the fuel.

The DOE Standardized SNF Canister was developed based on the recognition that DOE-owned SNF would not be accepted at a future repository without the appropriate packaging. The canister is designed to remain closed once it has been loadeda. Selecting a single canister for all DOE-owned SNF eliminated the fear that each DOE site would independently develop its own systems. Additionally, by crediting the standardized canister integrity on the basis of ensuring radiological and criticality safety during storage, transport, and preclosure disposal operations, the standardized canister provided an avenue for avoiding the characterization costs (i.e., cost and exposure) and other technical challenges associated with the traditional approach of relying on fuel-specific properties as the basis for demonstrating compliance with the regulator.

Idaho National Laboratory (INL) is initiating activities to ensure the continued operation of the Advanced Test Reactor (ATR) by providing alternative and redundant storage options for the spent ATR fuel. The DOE Office of Environmental Management (EM) has recently initiated studies to understand and improve the technical basis for long-term dry storage of aluminum clad spent nuclear fuel (e.g., ATR and High Flux Isotope Reactor [HFIR]) (Connolly 2018). While currently in the lab-scale phase, the next step involves validation and verification $(\mathrm{V} \& \mathrm{~V})$ of the lab-scale results. One method to perform $\mathrm{V} \& \mathrm{~V}$ is to load ATR spent fuel into an instrumented DOE Standardized SNF Canister as a demonstration. In order to minimize the need for repackaging before disposal and to provide a representative environment in a demonstration, the fuel is planned to be loaded with an appropriate criticality control mechanism, such as neutron absorbing basket material.

This report compares and examines past criticality evaluations performed on ATR fuel elements loaded within an 18-inch DOE Standardized SNF Canister. After comparing the two previous evaluations (BSC 2003, OCRWM 2004), this report focuses on changing the material from a Ni-Cr-Mo-Gd Alloy, also known as Advanced Neutron Absorber (ANA), to a borated stainless steel. The goal of this report is to provide additional information for the neutron absorbers that may be loaded in the DOE Standardized SNF Canister. It is assumed loading a demonstration canister that utilizes borated stainless steel could be deployed in a faster timeframe than it would take with ANA. Two previous reports, History and Status of DOE's Standardized Canister (Petersen 2019a) and Neutron Absorber Considerations for the DOE

a The canister may be cut open to satisfy retrievability of SNF. 
Standardized Canister (Petersen 2019b), document the history of the standardized canister and the history of the basket materials proposed to be used in the DOE standardized canister, respectively.

\section{PAST STUDIES AND CONFIGURATIONS}

In 2003 and 2004, Bechtel SAIC Company (BSC) and the Office of Civilian Radioactive Waste Management (OCRWM) evaluated the criticality of ATR fuel in a DOE Standardized SNF Canister for a variety of conditions (BSC 2003, OCRWM 2004). The materials, dimensions, and assumptions used in the two evaluations differed in many cases. Section 2.1 gives the dimensions and materials of an ATR element, the DOE Standardized SNF Canister, a U. S. Department of Energy high-level waste (DHLW) canister, and the codisposal waste package. Section 2.2 summarizes the 2003 BSC study, including the assumptions and results. Section 2.3 summarizes the 2004 OCRWM study, including the assumptions and results. Section 2.4 explicitly points out the differences in the two studies.

\subsection{Dimensions and Materials}

\subsubsection{Dimensions and Geometry}

This section specifies the dimensions and geometries used in the BSC (BSC 2003) and OCRWM (OCRWM 2004) evaluations for an ATR fuel element, the DOE Standardized SNF Canister, the DHLW canister, and the codisposal waste package. These same dimensions and materials are used for the subsequent evaluation substituting borated stainless steel for ANA.

\subsubsection{ATR Fuel Element}

A typical ATR fuel element consists of 19 curved aluminum-clad uranium aluminide (UAlx) plates containing highly enriched (93 $\left.\pm 1 \mathrm{wt} \%{ }_{235} \mathrm{U}\right)$ uranium (Reed 1992). The highest nominal fissile loading $(235 \mathrm{U})$ of the fresh fuel element is $1,075 \mathrm{~g}$ (Paige, 1969). The allowable uncertainty in the fuel loading is one percent, or $10.75 \mathrm{~g}$ (INEEL 2003). The highest fissile loading of $1,085.75 \mathrm{~g}$ was considered in both the BSC and OCRWM evaluations. Figure 1 illustrates an ATR element. 


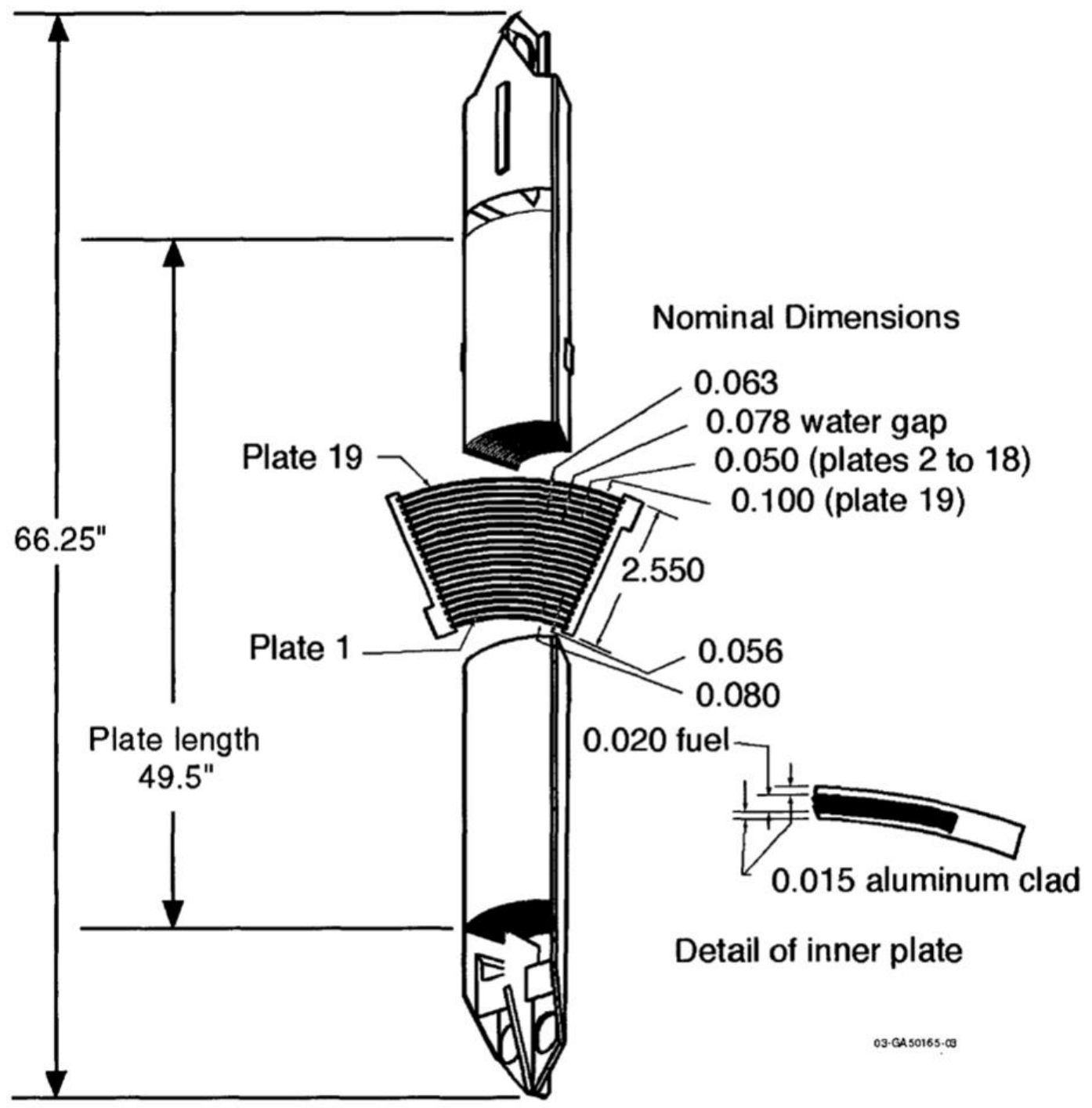

ATR Fuel

Figure 1. Typical ATR element.

For the purpose of disposal, the fuel elements are cropped to a length of $49.5 \mathrm{in}$. (length of the fuel plates) by removing the upper and lower end boxes. The fuel plates are $49.5 \mathrm{in}$. long with a fuel zone that is $48.76 \mathrm{in.} \mathrm{long.} \mathrm{The} \mathrm{following} \mathrm{data} \mathrm{are} \mathrm{characteristics} \mathrm{for} \mathrm{the} \mathrm{ATR} \mathrm{7F} \mathrm{fuel} \mathrm{elements} \mathrm{(Paige} \mathrm{1969).} \mathrm{The}$ thickness of each plate is 0.05 in. except Plates 1 and 19, which are 0.08 in. and 0.1 in., respectively. The fuel matrix section in each plate is $0.02 \mathrm{in}$. thick. The cladding is made of aluminum (T-6061). The plates are held in place by aluminum side plates that are $2.55 \mathrm{in}$. wide (the thickness of the fuel assembly), 0.187 in. thick, and $49.5 \mathrm{in}$. long. When assembled, the angle of curvature of the fuel elements is 45 degrees with an inner radius of 2.964 inches. The BSC and OCRWM studies have the same inner radius and $235 \mathrm{U}$ content as seen in Table 1, but they differ in plate arc length and fuel meat arc length as seen in Table 2 . It is unclear why the two studies used different references. Dimensions are listed in millimeters to adequately show the differences between the two evaluations. 
Table 1. Comparison of inner radius and $235 \mathrm{U}$ content between BSC and OCRWM.

\begin{tabular}{|c|c|c|}
\hline Plate Number & Inner Radius (mm) & $235 \mathrm{U}$ content $(\max )(\mathrm{g})$ \\
\hline 1 & 76.581 & 24.543 \\
\hline 2 & 80.5942 & 29.391 \\
\hline 3 & 83.8454 & 39.087 \\
\hline 4 & 87.0966 & 40.804 \\
\hline 5 & 90.3478 & 52.621 \\
\hline 6 & 93.599 & 55.146 \\
\hline 7 & 96.8502 & 57.57 \\
\hline 8 & 100.1014 & 59.994 \\
\hline 9 & 103.3526 & 62.418 \\
\hline 10 & 106.6038 & 64.842 \\
\hline 11 & 109.855 & 67.266 \\
\hline 12 & 113.1062 & 69.69 \\
\hline 13 & 116.3574 & 72.114 \\
\hline 14 & 119.6086 & 74.538 \\
\hline 15 & 122.8598 & 77.063 \\
\hline 16 & 126.111 & 64.64 \\
\hline 17 & 129.3622 & 66.559 \\
\hline 18 & 132.6134 & 54.338 \\
\hline 19 & 135.8646 & 53.126 \\
\hline
\end{tabular}

Table 2. Comparison of plate arc length and fuel meat arc length between BSC and OCRWM.

\begin{tabular}{|c|c|c|c|c|}
\hline $\begin{array}{c}\text { Plate } \\
\text { Number }\end{array}$ & $\begin{array}{c}\text { Plate Arc Length } \\
(\mathbf{m m})\end{array}$ & $\begin{array}{c}\text { OCRWM } \\
\text { Plate Arc Length } \\
(\mathbf{m m})\end{array}$ & $\begin{array}{c}\text { BSC } \\
\text { Fuel Meat Arc } \\
\text { Length (mm) }\end{array}$ & $\begin{array}{c}\text { OCRWM } \\
\text { Fuel Meat Arc } \\
\text { Length (mm) }\end{array}$ \\
\hline 1 & 54.102 & 67.818 & 41.3258 & 55.118 \\
\hline 2 & 55.4228 & 71.374 & 49.2506 & 64.008 \\
\hline 3 & 57.9882 & 74.676 & 51.816 & 67.056 \\
\hline 4 & 60.5028 & 77.978 & 54.3306 & 70.358 \\
\hline 5 & 63.0936 & 81.28 & 56.9214 & 73.66 \\
\hline 6 & 65.6336 & 84.582 & 59.4614 & 76.962 \\
\hline 7 & 68.199 & 87.63 & 62.0268 & 80.264 \\
\hline 8 & 70.739 & 90.932 & 64.5668 & 83.312 \\
\hline 9 & 73.3044 & 94.234 & 67.1322 & 86.614 \\
\hline 10 & 75.8444 & 97.536 & 69.6722 & 89.916 \\
\hline 11 & 78.4098 & 100.838 & 72.2376 & 93.218 \\
\hline 12 & 80.9752 & 103.886 & 74.803 & 96.266 \\
\hline
\end{tabular}




\begin{tabular}{|c|c|c|c|c|}
\hline $\begin{array}{c}\text { Plate } \\
\text { Number }\end{array}$ & $\begin{array}{c}\text { BSC } \\
\text { Plate Arc Length } \\
(\mathbf{m m})\end{array}$ & $\begin{array}{c}\text { OCRWM } \\
\text { Plate Arc Length } \\
(\mathbf{m m})\end{array}$ & $\begin{array}{c}\text { BSC } \\
\text { Fuel Meat Arc } \\
\text { Length (mm) }\end{array}$ & $\begin{array}{c}\text { OCRWM } \\
\text { Fuel Meat Arc } \\
\text { Length (mm) }\end{array}$ \\
\hline 13 & 83.5152 & 107.188 & 77.343 & 99.568 \\
\hline 14 & 86.0806 & 110.49 & 79.9084 & 102.87 \\
\hline 15 & 88.6206 & 113.538 & 82.4484 & 106.172 \\
\hline 16 & 91.186 & 116.84 & 85.0138 & 109.22 \\
\hline 17 & 93.726 & 120.142 & 87.5538 & 112.522 \\
\hline 18 & 96.2914 & 123.19 & 88.8492 & 114.808 \\
\hline 19 & 100.8634 & 127.254 & 88.0872 & 114.3 \\
\hline
\end{tabular}

\subsubsection{DOE Standardized SNF Canister}

The DOE Standardized SNF Canister has four different configurations with diameters of 18 in. or 24 in. with lengths of $10 \mathrm{ft}$. or $15 \mathrm{ft}$. The previous evaluations examined for this report stacked two baskets containing 10 ATR elements within the 18 in., $10 \mathrm{ft}$ canister. The conceptual design for the DOE Standardized SNF Canister is taken from DOE (Morton 1999). The canister is a right circular cylinder pipe made of stainless steel (Type 316L) with an outside diameter of $18 \mathrm{in}$. and a wall thickness of 0.375 in. The minimum internal length of the canister is $100 \mathrm{in}$., and the nominal overall length is $\sim 118$ in. (approximately $10 \mathrm{ft}$ ). There is a curved carbon steel (American Society of Testing Materials [ASTM] A 516 Grade 70 ) impact plate, 2.0 in. thick, at the top and bottom boundaries of the canister. Dished heads seal the ends of the canister. The maximum loaded mass is $2,270 \mathrm{~kg}$ for the short canister (Morton 1999). A sketch of the canister is shown in Figure 2. The nominal dimensions of the canister are used for the analyses and are summarized in Table 3. The canister in the BSC and OCRWM evaluations is the same. Dimensions are listed in millimeters for consistency. 


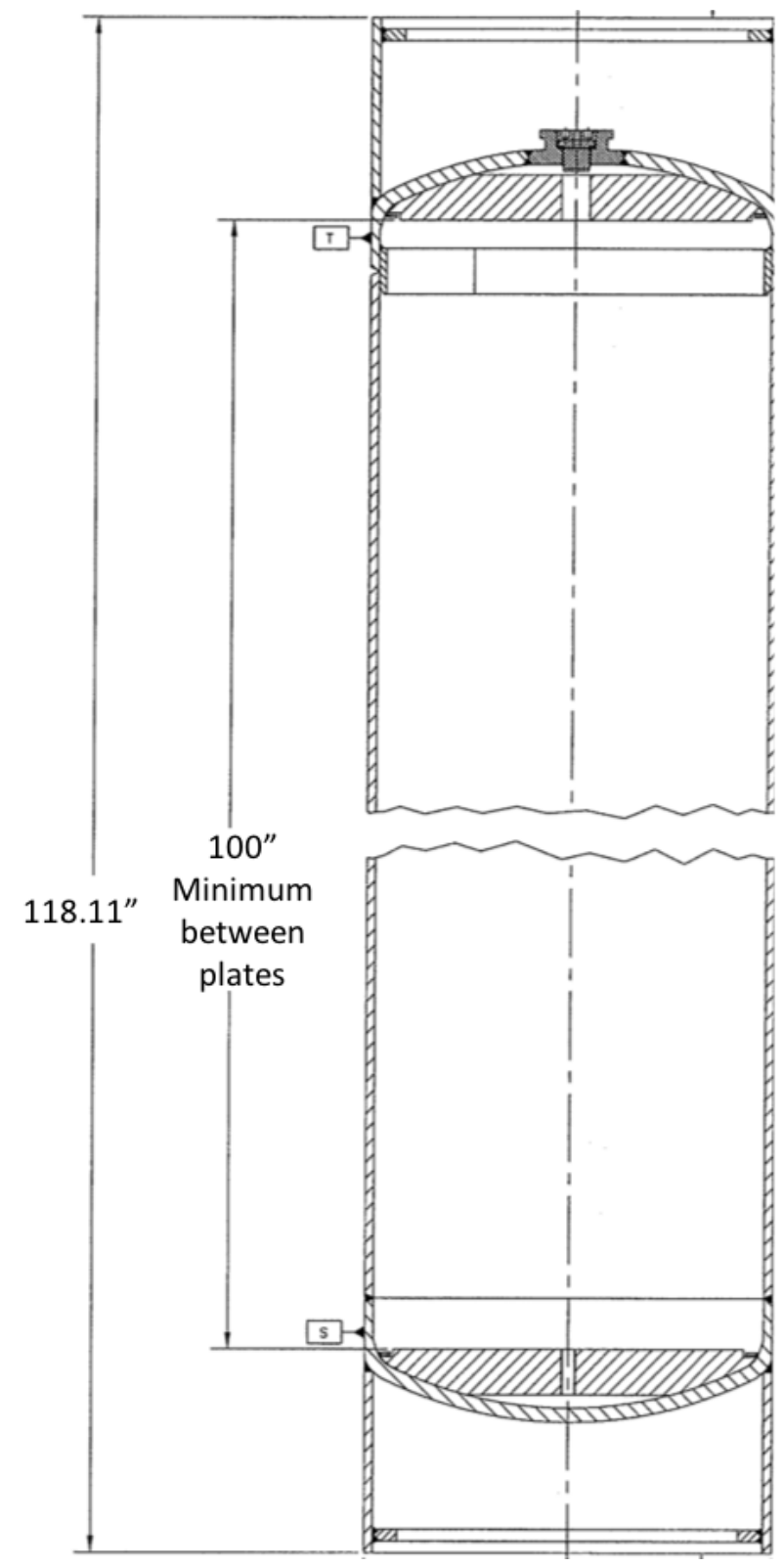

Figure 2. Drawing of the 10-foot DOE Standardized SNF Canister. 
Table 3. Comparison of materials and dimensions for the DOE Standardized SNF Canister. The BSC and OCRWM evaluation use the same dimensions for the DOE Standardized SNF Canister.

\begin{tabular}{|c|c|c|c|}
\hline Component & Material & Parameter & $\begin{array}{c}\text { Dimension } \\
(\mathbf{m m})\end{array}$ \\
\hline Canister vessel & $\begin{array}{c}\text { Stainless steel type } \\
316\end{array}$ & Thickness & 9.525 \\
\cline { 3 - 4 } & & Outer diameter & 457.2 \\
\cline { 3 - 4 } & & Inner diameter & 438.15 \\
\cline { 3 - 4 } & & Usable length & 2,540 \\
\cline { 3 - 4 } & & Canister length & 2,999 \\
\hline Impact plate & Stainless steel type & Thickness & 50.8 \\
& 316 & & \\
\hline
\end{tabular}

The DOE Standardized SNF Canister typically contains a basket structure to hold the spent fuel. The basket design is modified for each specific spent fuel type. The basket structure provides material for controlling criticality, provides structural support, and acts as a guide for assemblies during loading. ATR fuel used a Type 1A basket made of a neutron absorbing material. The Type 1A basket is shown in Figure 3 and can accommodate ATR, Massachusetts Institute of Technology (MIT), Peach Bottom, Oak Ridge Research Reactor (ORR), and Missouri Research Reactor (MURR) fuel types. While this evaluation focuses on just ATR fuel, there have been brief discussions on combining different fuel types into a single canister.

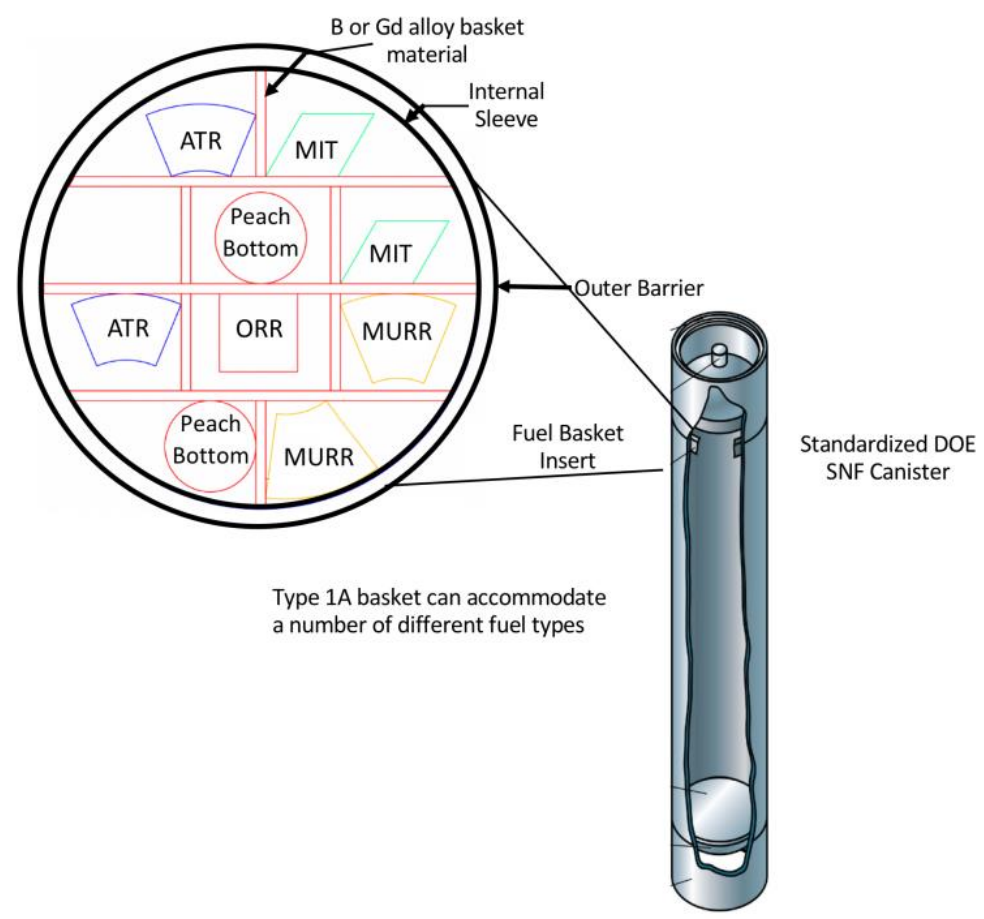

Figure 3. DOE Standardized SNF Canister and Type 1A basket. 
Both the BSC and OCRWM evaluations used a basket structure fabricated from a low-carbon nickelchromium-molybdenum-gadolinium alloy, termed the ANA, with a Gd content of $2.0 \mathrm{wt} \%$. The basket structure contains two axial identical sections (layers) separated by a circular plate with a thickness of $0.147 / 0.375 \mathrm{in}$. This is made from ANA in the BSC evaluation and 304L stainless steel in the OCRWM evaluation. The length of each section was considered to be slightly less than 50 in. All plates in the basket have been assumed to have a thickness of 0.375 in. in the OCRWM evaluation. The BSC evaluation tests 0.25 and 0.375 in. thick basket material. A cross-sectional view is shown in Figure 4 . The basket is surrounded by a type 304L stainless steel sleeve with an outer diameter of just under 17 in. with a thickness of less than $0.1 \mathrm{in}$. The Type 1A basket utilized for ATR SNF contains ten fuel locations for each axial section. The basket compartments are delimited by horizontal and vertical plates. Three horizontal plates are placed symmetrically around the center of the stainless steel sleeve. The structure also contains three vertical plates: one extending outside the upper and bottom horizontal plates (centered on the vertical diameter of the sleeve) and two placed symmetrically between the horizontal plates. A summary of pertinent dimensions and materials from both the BSC and OCRWM evaluations is provided in Table 4. Dimensions are listed in millimeters to adequately show the differences in the two evaluations.

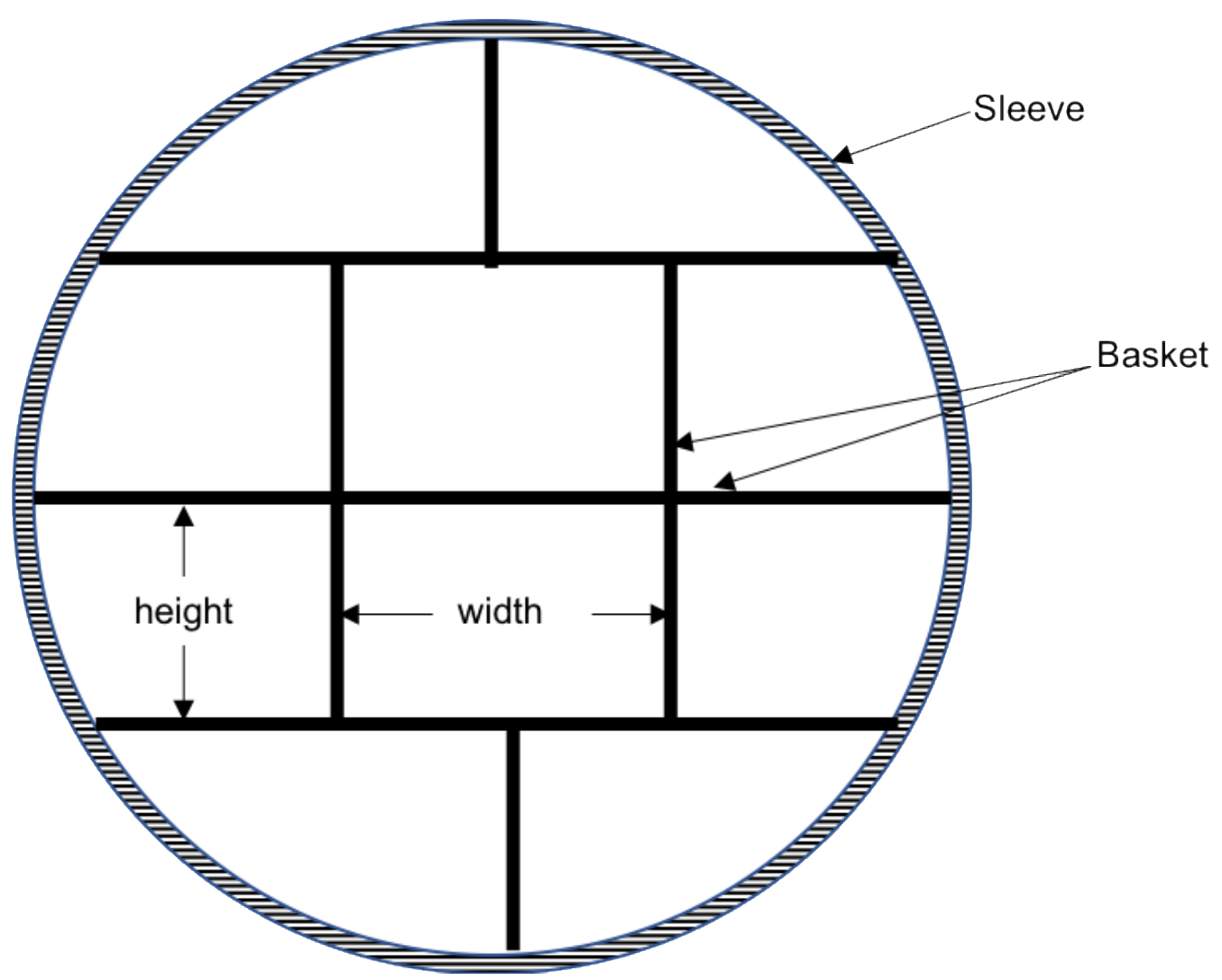

Figure 4. Type A1 basket used in the evaluations.

Table 4. Comparison of materials and dimensions used for canister internals in the BSC and OCRWM analyses.

\begin{tabular}{|c|c|c|c|c|}
\hline Component & Material & Parameter & $\begin{array}{c}\text { BSC } \\
\text { Dimension } \\
(\mathbf{m m})\end{array}$ & $\begin{array}{c}\text { OCRWM } \\
\text { Dimension } \\
(\mathbf{m m})\end{array}$ \\
\hline
\end{tabular}




\begin{tabular}{|c|c|c|c|c|}
\hline \multirow{2}{*}{ Sleeve } & Stainless steel type & Thickness & 10.875 & 10.557 \\
\cline { 3 - 5 } & \multirow{2}{*}{ 304L } & Outer diameter & 419.675 & 429.25 \\
\cline { 3 - 5 } & \multirow{2}{*}{ ANA } & Inner diameter & 415.925 & 426.136 \\
\hline \multirow{2}{*}{ Basket } & Thickness & $6.35 \mathrm{a}$ & 9.525 \\
\cline { 3 - 5 } & & Width & 138.2214 & 136.5 \\
\cline { 3 - 5 } & & Height & 91.0607 & 101.1 \\
\cline { 3 - 5 } & & Entire Length & 2,540 & 2,540 \\
\hline Divider plate & ANA/stainless steelb & Thickness & 3.75 & 9.525 \\
\hline
\end{tabular}

a The BSC evaluation used two different thicknesses, $6.35 \mathrm{~mm}$ and $9.525 \mathrm{~mm}$.

b ANA was used in the BSC evaluation while stainless steel was used in the OCRWM evaluation.

\subsubsection{DHLW Glass Pour Canister}

The Savannah River Site (SRS) Defense Waste Processing Facility (DWPF) high-level radioactive waste canister, as shown in Figure 5 is a cylindrical stainless steel Type 304L shell. The outer diameter of the cylindrical shell is $2 \mathrm{ft}$. The nominal length of cylindrical shell is $10 \mathrm{ft}$. and approximately $9.8 \mathrm{ft}$. in the BSC and OCRWM evaluations, respectively. The nominal dimensions of the canister are used for the analyses and are summarized in Table 5. Dimensions are listed in millimeters to adequately show the differences in the two evaluations.

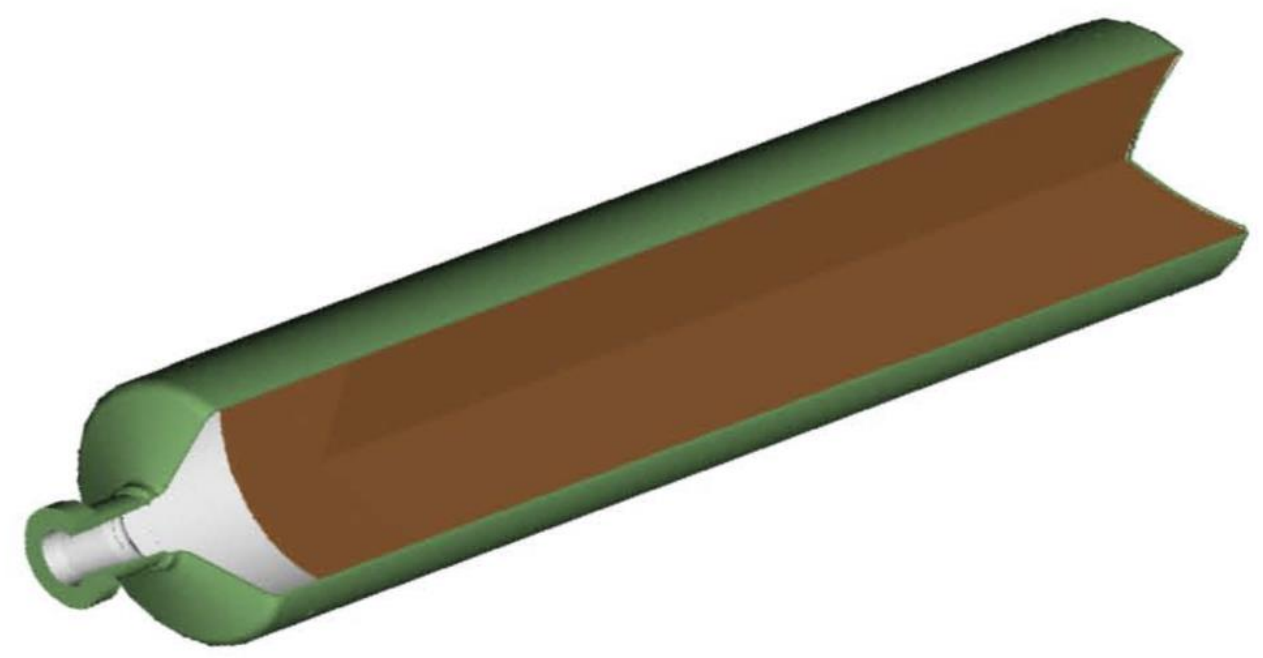

Figure 5. DHLW glass pour canister (BSC 2004) 
Table 5. Comparison of materials and dimensions used for the DHLW canister in the BSC and OCRWM analyses.

\begin{tabular}{|c|c|c|c|c|}
\hline \multirow{2}{*}{ Component } & Material & Parameter & $\begin{array}{c}\text { BSC } \\
\text { Dimension } \\
(\mathbf{m m})\end{array}$ & $\begin{array}{c}\text { OCRWM } \\
\text { Dimension } \\
(\mathbf{m m})\end{array}$ \\
\hline \multirow{2}{*}{$\begin{array}{c}\text { DHLW glass pour } \\
\text { canisters }\end{array}$} & $\begin{array}{c}\text { Stainless steel type } \\
\text { 304L }\end{array}$ & Outer diameter & 610 & 610 \\
\cline { 3 - 5 } & & Wall thickness & 10.5 & 9.525 \\
\cline { 2 - 5 } & & Length & 3037.5 & 3000.0 \\
\hline
\end{tabular}

\subsubsection{Codisposal Waste Package}

The 5DHLW/DOE SNF short waste package contains five DHLW glass pour canisters spaced radially around an 18-in. DOE Standardized SNF Canister. A cross section of the codisposal waste package is illustrated in Figure 6.

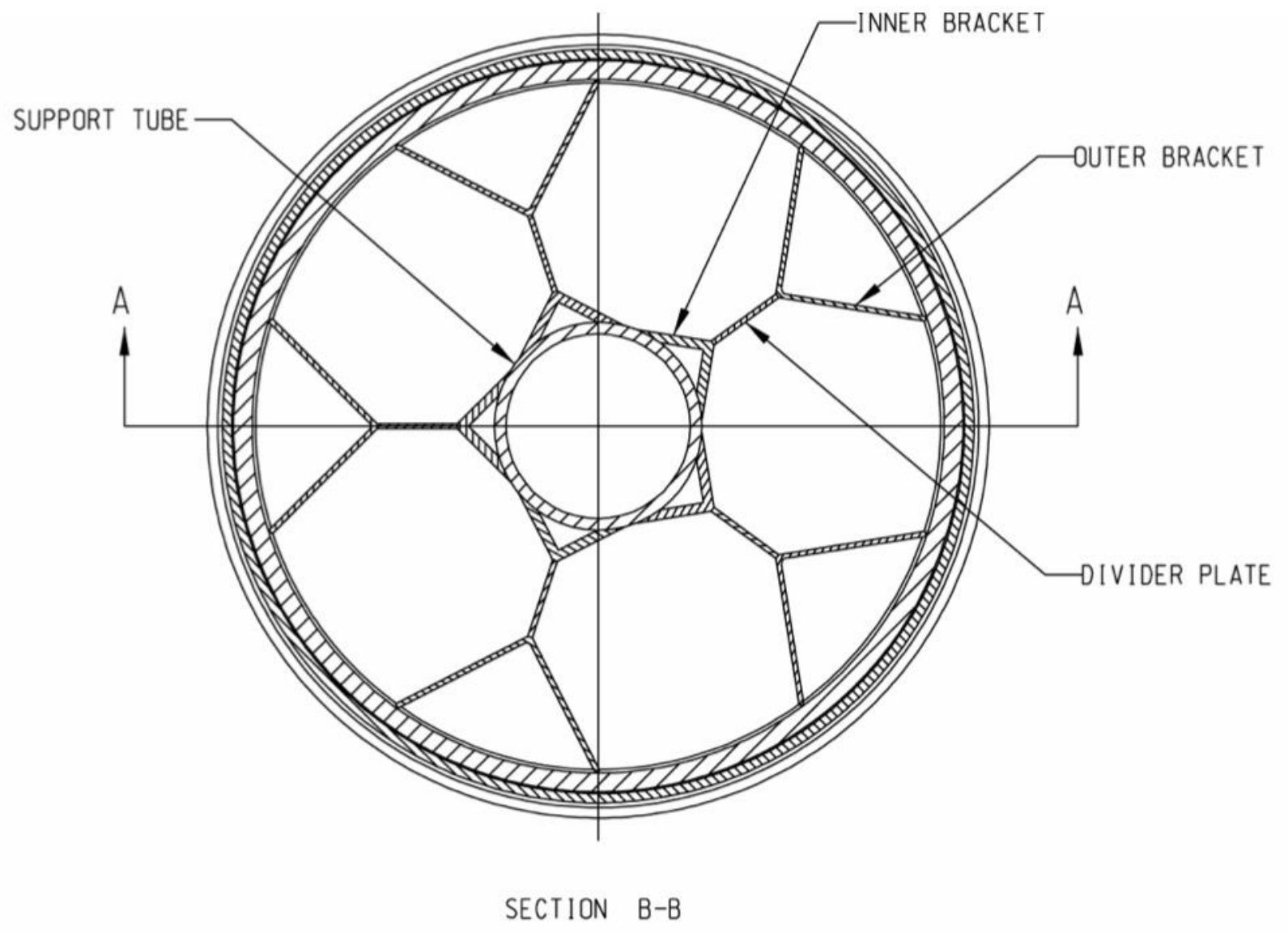

Figure 6. Cross section of the DHLW/DOE SNF codisposal waste package. 
The dimensions differ slightly in the 2003 BSC and 2004 OCRWM evaluations. The waste package barrier materials are typical of those used for commercial spent nuclear fuel waste containers. The inner vessel is composed of $\sim 2$ in. of stainless steel type 316 (also identified as SA240) and serves for structural support and as a corrosion-resistant material. The outer corrosion barrier is composed of $\sim 1 \mathrm{in}$. highnickel alloy ASTM B 575 (Alloy 22) and serves as a corrosion resistant material. The outside diameter of the waste container is 80 to 80.5 in. and the length of the inner cavity is slightly less than 10 feet. The inner vessel lids are $2 \mathrm{in}$. thick, the middle lid is $1 / 2 \mathrm{in}$. thick, and the outer lid is $1 \mathrm{in}$. thick. There is a 1.2-in.-thick closure lid gap between the inner vessel lid and middle lid and a little less than a 2-in. gap between the middle lid and the outer lid.

The DOE Standardized SNF Canister is placed in a 1.25-in.-thick carbon steel (ASTM A 516 Grade 70 or UNS K02700) support tube with a 22.244 in. nominal outer diameter. The support tube is connected to the inside wall of the waste package by web-like carbon steel (ASTM A 516 Grade 70 or UNS K02700) support plates that form five emplacement positions for the DHLW glass pour canisters, equally spaced at angles around the center support tube. The support tube and plates are slightly less than 10 feet long. A summary of pertinent dimensions and materials from both the BSC and OCRWM evaluations is provided in Table 6. Dimensions are listed in millimeters to adequately show the differences in the two evaluations.

Table 6. Comparison of materials and dimensions used for the codisposal waste package in the BSC and OCRWM analyses.

\begin{tabular}{|c|c|c|c|c|}
\hline Component & Material & Parameter & $\begin{array}{c}\text { BSC } \\
\text { Dimension } \\
(\mathrm{mm})\end{array}$ & $\begin{array}{c}\text { OCRWM } \\
\text { Dimension } \\
\quad(\mathrm{mm})\end{array}$ \\
\hline \multirow[t]{3}{*}{ Outer corrosion barrier } & \multirow[t]{3}{*}{ High-nickel alloy } & Thickness & 25 & 25.4 \\
\hline & & Outer diameter & 2,040 & $2,044.7$ \\
\hline & & Inner diameter & 1,990 & $1,993.9$ \\
\hline \multirow[t]{4}{*}{ Inner vessel } & \multirow{4}{*}{$\begin{array}{l}\text { Stainless steel type } \\
316\end{array}$} & Thickness & 50 & 50.8 \\
\hline & & Outer diameter & 1,980 & $1,984.5$ \\
\hline & & Inner diameter & 1,880 & $1,882.9$ \\
\hline & & Inner length & 3,040 & $3,013.2$ \\
\hline Outer lid & High-nickel alloy & Thickness & 25.4 & 25.4 \\
\hline Middle lid & High-nickel alloy & Thickness & 10 & 12.7 \\
\hline Inner vessel lid & $\begin{array}{c}\text { Stainless steel type } \\
316\end{array}$ & Thickness & 50.8 & 50.8 \\
\hline $\begin{array}{l}\text { Gap between the middle } \\
\text { lid and outer lid }\end{array}$ & Air & Thickness & 30 & 30.2 \\
\hline $\begin{array}{l}\text { Gap between the inner } \\
\text { vessel lid and middle lid }\end{array}$ & Air & Thickness & 47.23 & 49.467 \\
\hline Support tube & Carbon steel & Outer diameter & 565 & 565.0 \\
\hline
\end{tabular}




\begin{tabular}{|c|c|c|c|c|}
\hline \multirow{2}{*}{ Component } & Material & Parameter & $\begin{array}{c}\text { BSC } \\
\text { Dimension } \\
(\mathbf{m m})\end{array}$ & $\begin{array}{c}\text { OCRWM } \\
\text { Dimension } \\
(\mathbf{m m})\end{array}$ \\
\hline \multirow{2}{*}{ Inner bracket } & \multirow{2}{*}{ Carbon steel } & Inner diameter & 501.5 & 501.5 \\
\cline { 3 - 5 } & & Length & 3,030 & $3,000.5$ \\
\cline { 3 - 5 } & & Thickness & 25.4 & 25.4 \\
\hline Outer bracket & Carbon steel & Thickness & 12.7 & $3,000.5$ \\
\cline { 3 - 5 } & & Length & 3,030 & $3,000.5$ \\
\hline
\end{tabular}

\subsubsection{Material Composition}

This section lists the materials used in the BSC and OCRWM evaluations. In most cases, the same materials are used in each study, but they may have slight differences in composition for the criticality evaluations performed. While borated stainless steel is not used in either of the BSC or the OCRWM evaluations, the materials composition is provided in this section for completion. All material compositions are separated by weight percent except those for pre- and post-breach clay. These values are separated by the expected mass of the element after a number of years of emplacement. The material compositions used in this analysis are listed in Tables 7-18.

Table 7. Comparison of material composition of stainless steel 304L for the BSC and OCRWM. Stainless steel 304L has the same composition in both analyses.

\begin{tabular}{|c|c|}
\hline \multicolumn{2}{|c|}{ Stainless Steel 304L } \\
\hline Element & Compositiona (wt \%) \\
\hline $\mathrm{C}$ & 0.3 \\
\hline $\mathrm{Mn}$ & 2 \\
\hline $\mathrm{P}$ & 0.045 \\
\hline $\mathrm{S}$ & 0.03 \\
\hline $\mathrm{Si}$ & 0.75 \\
\hline $\mathrm{Cr}$ & 19 \\
\hline $\mathrm{Ni}$ & 10 \\
\hline $\mathrm{Mo}$ & 0 \\
\hline $\mathrm{N}$ & 0.1 \\
\hline $\mathrm{Fe}$ & 68.045 \\
\hline Densityb $(\mathrm{g} / \mathrm{cm} 3)$ & $7.94 \mathrm{~b}$ \\
\hline
\end{tabular}

Sources: a ASME 2001 Section II, Part A, SA-240, Table 1.

b ASTM G 1-90, Table X1.1 
Table 8. Comparison of material composition of stainless steel 316L for the BSC and OCRWM analyses. stainless steel 316L has the same composition in both analyses.

\begin{tabular}{|c|c|}
\hline \multicolumn{2}{|c|}{ Stainless Steel 316L } \\
\hline Element & Compositiona (wt \%) \\
\hline $\mathrm{C}$ & 0.03 \\
\hline $\mathrm{N}$ & 0.1 \\
\hline $\mathrm{Si}$ & 1 \\
\hline $\mathrm{P}$ & 0.045 \\
\hline $\mathrm{S}$ & 0.03 \\
\hline $\mathrm{Cr}$ & 17 \\
\hline $\mathrm{Mn}$ & 2 \\
\hline $\mathrm{Ni}$ & 12 \\
\hline $\mathrm{Mo}$ & 2.5 \\
\hline Fe & 65.295 \\
\hline Density (g/cm3) & $7.98 \mathrm{~b}$ \\
\hline
\end{tabular}

Sources: a ASME 2001 Section II, Part A, SA-240, Table 1.

b ASTM G 1-90, Table X1.1

Table 9. Comparison of material composition of stainless steel 316 for the BSC and OCRWM analyses. BSC did not use stainless steel 316 in its evaluation.

\begin{tabular}{|c|c|}
\hline \multicolumn{2}{|c|}{ Stainless Steel 316 } \\
\hline Element & OCRWM Compositiona (wt \%) \\
\hline $\mathrm{C}$ & 0.02 \\
\hline $\mathrm{N}$ & 0.08 \\
\hline $\mathrm{Si}$ & 0.75 \\
\hline $\mathrm{P}$ & 0.045 \\
\hline $\mathrm{S}$ & 0.03 \\
\hline $\mathrm{Cr}$ & 17 \\
\hline $\mathrm{Mn}$ & 2 \\
\hline $\mathrm{Ni}$ & 12 \\
\hline $\mathrm{Mo}$ & 2.5 \\
\hline $\mathrm{Fe}$ & 65.575 \\
\hline Density $(\mathrm{g} / \mathrm{cm} 3)$ & $7.98 \mathrm{~b}$ \\
\hline
\end{tabular}

Sources: a ASME 2001 Section II, Part A, SA-240, Table 1.

b ASTM G 1-90, Table X1.1 
Table 10. Comparison of material composition of alloy 22 for the BSC and OCRWM analyses. Alloy 22 has the same composition in both analyses.

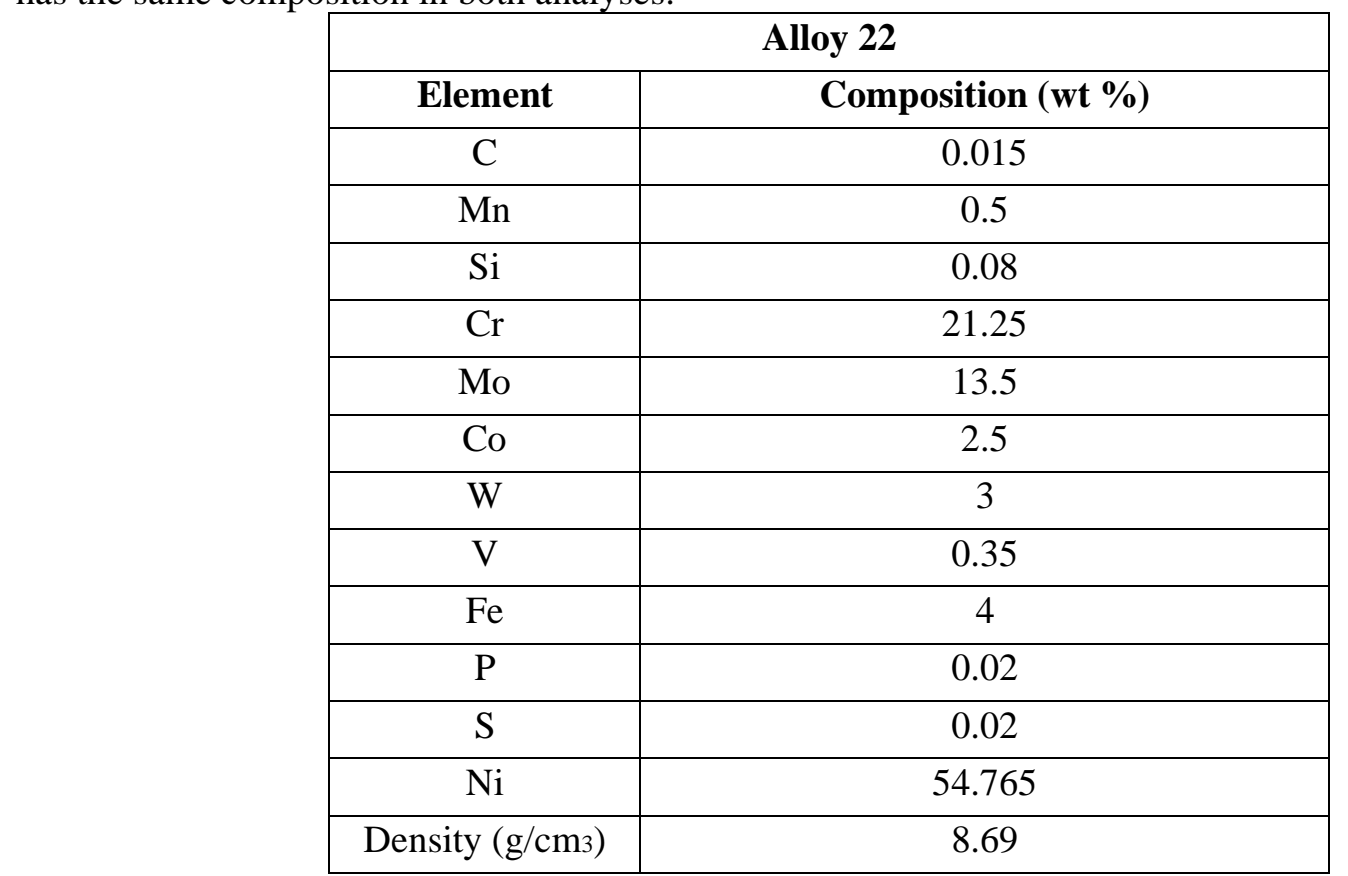

Source: DTN: MO0003RIB00071.000.

Table 11. Comparison of material composition of carbon steel A516 Grade 70 for the BSC and OCRWM analyses.

\begin{tabular}{|c|c|c|}
\hline \multicolumn{3}{|c|}{ Carbon Steel A516 Grade 70 } \\
\hline Element & $\begin{array}{c}\text { BSC } \\
\text { Composition }\end{array}$ (wt \%) & $\begin{array}{c}\text { OCRWM } \\
\text { Compositionb (wt \%) }\end{array}$ \\
\hline $\mathrm{C}$ & 0.3 & 0.28 \\
\hline $\mathrm{Mn}$ & 1.025 & 1.045 \\
\hline $\mathrm{P}$ & 0.035 & 0.035 \\
\hline $\mathrm{S}$ & 0.035 & 0.035 \\
\hline $\mathrm{Si}$ & 0.275 & 0.29 \\
\hline $\mathrm{Fe}$ & 98.33 & 98.315 \\
\hline Density $\left(\mathrm{g} / \mathrm{cm}_{3}\right)$ & 7.85 & $7.85 \mathrm{c}$ \\
\hline
\end{tabular}

Sources: a ASTM A 276-91a, (UNS S31603).

b ASTM A516/A 516M-01, Table 1.

c ASTM G 1-90, Table X1.1

Table 12. Comparison of material composition of aluminum cladding/aluminum 6061 for the BSC and OCRWM analyses.

\begin{tabular}{|c|c|c|}
\hline \multicolumn{3}{|c|}{ Aluminum Cladding/Aluminum 6061 } \\
\hline Element & BSC & OCRWM \\
& Compositiona (wt \%) & Compositionb (wt \%) \\
\hline
\end{tabular}


Sources: a (BSC 2003)

\begin{tabular}{|c|c|c|}
\hline $\mathrm{Mg}$ & 1 & 1 \\
\hline $\mathrm{Si}$ & 0.6 & 0.6 \\
\hline $\mathrm{Fe}$ & 0 & 0.7 \\
\hline $\mathrm{Cu}$ & 0.28 & 0.275 \\
\hline $\mathrm{Cr}$ & 0.2 & 0.195 \\
\hline $\mathrm{Mn}$ & 0 & 0.15 \\
\hline $\mathrm{Zn}$ & 0 & 0.25 \\
\hline $\mathrm{Ti}$ & 0 & 0.15 \\
\hline $\mathrm{Al}$ & 97.92 & 96.68 \\
\hline Density $\left(\mathrm{g} / \mathrm{cm}_{3}\right)$ & $2.702 \mathrm{a}$ & $2.7065 \mathrm{c}$ \\
\hline
\end{tabular}

b ASM International 1990, p. 102.

c (OCRWM 2004)

Table 13. Comparison of material composition of SRS DHLW Glass for the BSC and OCRWM analyses. SRS DHLW glass has the same composition in both analyses.

\begin{tabular}{|c|c|}
\hline \multicolumn{2}{|c|}{ Savannah River Site DHLW Glass } \\
\hline Element & Composition (wt \%) \\
\hline $\mathrm{O}$ & $4.48 \mathrm{E}+01$ \\
\hline $\mathrm{U}-234$ & $3.28 \mathrm{E}-04$ \\
\hline $\mathrm{U}-235$ & $4.35 \mathrm{E}-03$ \\
\hline $\mathrm{U}-236$ & $1.04 \mathrm{E}-03$ \\
\hline $\mathrm{U}-238$ & $1.87 \mathrm{E}+00$ \\
\hline $\mathrm{Pu}-238$ & $5.18 \mathrm{E}-03$ \\
\hline $\mathrm{Pu}-239$ & $1.24 \mathrm{E}-02$ \\
\hline $\mathrm{Pu}-240$ & $2.28 \mathrm{E}-03$ \\
\hline $\mathrm{Pu}-241$ & $9.69 \mathrm{E}-04$ \\
\hline $\mathrm{Pu}-242$ & $1.92 \mathrm{E}-04$ \\
\hline $\mathrm{Cs}-133$ & $4.09 \mathrm{E}-02$ \\
\hline $\mathrm{Cs}-135$ & $5.16 \mathrm{E}-03$ \\
\hline $\mathrm{Ba}-137$ & $1.13 \mathrm{E}-01$ \\
\hline $\mathrm{Al}$ & $2.33 \mathrm{E}+00$ \\
\hline $\mathrm{S}$ & $1.29 \mathrm{E}-01$ \\
\hline $\mathrm{Ca}$ & $6.62 \mathrm{E}-01$ \\
\hline $\mathrm{P}$ & $1.41 \mathrm{E}-02$ \\
\hline $\mathrm{Cr}$ & $8.26 \mathrm{E}-02$ \\
\hline $\mathrm{Ag}$ & $5.03 \mathrm{E}-02$ \\
\hline $\mathrm{Ni}$ & $7.35 \mathrm{E}-01$ \\
\hline $\mathrm{Pb}$ & $6.10 \mathrm{E}-02$ \\
\hline
\end{tabular}




\begin{tabular}{|c|c|}
\hline \multicolumn{2}{|c|}{ Savannah River Site DHLW Glass } \\
\hline Element & Composition (wt \%) \\
\hline $\mathrm{Si}$ & $2.19 \mathrm{E}+01$ \\
\hline $\mathrm{Th}$ & $1.86 \mathrm{E}-01$ \\
\hline $\mathrm{Ti}$ & $5.97 \mathrm{E}-01$ \\
\hline $\mathrm{Zn}$ & $6.46 \mathrm{E}-02$ \\
\hline $\mathrm{B}-10$ & $5.92 \mathrm{E}-01$ \\
\hline $\mathrm{B}-11$ & $2.62 \mathrm{E}+00$ \\
\hline $\mathrm{Li}-6$ & $9.60 \mathrm{E}-02$ \\
\hline $\mathrm{Li}-7$ & $1.38 \mathrm{E}+00$ \\
\hline $\mathrm{F}$ & $3.19 \mathrm{E}-02$ \\
\hline $\mathrm{Cu}$ & $1.53 \mathrm{E}-01$ \\
\hline $\mathrm{Fe}$ & $7.39 \mathrm{E}+00$ \\
\hline $\mathrm{K}$ & $2.99 \mathrm{E}+00$ \\
\hline $\mathrm{Mg}$ & $8.25 \mathrm{E}-01$ \\
\hline $\mathrm{Mn}$ & $1.56 \mathrm{E}+00$ \\
\hline $\mathrm{Na}$ & $8.63 \mathrm{E}+00$ \\
\hline $\mathrm{CI}$ & $1.16 \mathrm{E}-01$ \\
\hline Density $(\mathrm{g} / \mathrm{cm} 3)$ & 2.85 \\
\hline
\end{tabular}

Sources: a MOL.19990720.0403

b Preliminary Waste Form Characteristics Report (Stout and Lieder 1991) p. 2.2.1.1-4

The BSC analysis assumed the mass of an element of pre-breach clay after 53,241 years while the OCRWM analysis assumed the mass of an element of pre-breach clay after 15,072 years. The BSC analysis did not calculate a value for post-breach clay, so it extended the time of emplacement out to 53,241 years. The OCRWM analysis used a much shorter timeframe for pre-breach clay because it calculated a value for post-breach clay. The post-breach composition is made up of pre-breach clay with homogenized material associated with the decomposition of the SNF.

Table 14. Comparison of material composition of pre-breach clay for the BSC (53,241 years) and OCRWM (15,072 years) analyses.

\begin{tabular}{|c|c|c|}
\hline \multicolumn{3}{|c|}{ Pre-breach Clay } \\
\hline Element & $\begin{array}{c}\text { BSC Mass of Element after 53,241 } \\
\text { Years of Emplacement }(\mathbf{k g}) \mathbf{a}\end{array}$ & $\begin{array}{c}\text { OCRWM Mass of Element after } \\
\mathbf{1 5 , 0 7 2} \text { Years of Emplacement }(\mathbf{k g})_{\mathbf{b}}\end{array}$ \\
\hline $\mathrm{O}$ & $9.67 \mathrm{E}+03$ & $5.37 \mathrm{E}+03$ \\
\hline $\mathrm{Al}$ & $3.36 \mathrm{E}+02$ & $2.08 \mathrm{E}+02$ \\
\hline $\mathrm{Ba}$ & $2.15 \mathrm{E}+01$ & $1.35 \mathrm{E}+01$ \\
\hline $\mathrm{Ca}$ & $8.11 \mathrm{E}+01$ & $8.57 \mathrm{E}+01$ \\
\hline $\mathrm{F}$ & $1.04 \mathrm{E}+00$ & $7.43 \mathrm{E}-02$ \\
\hline $\mathrm{Fe}$ & $1.07 \mathrm{E}+04$ & $5.29 \mathrm{E}+03$ \\
\hline $\mathrm{H}$ & $7.14 \mathrm{E}+01$ & $4.02 \mathrm{E}+01$ \\
\hline $\mathrm{C}$ & $0.00 \mathrm{E}+00$ & $3.18 \mathrm{E}+01$ \\
\hline
\end{tabular}




\begin{tabular}{|c|c|c|}
\hline $\mathrm{P}$ & $5.09 \mathrm{E}+00$ & $2.19 \mathrm{E}+00$ \\
\hline $\mathrm{K}$ & $0.00 \mathrm{E}+00$ & $8.78 \mathrm{E}+01$ \\
\hline $\mathrm{Mg}$ & $9.05 \mathrm{E}+01$ & $7.59 \mathrm{E}+01$ \\
\hline $\mathrm{Mn}$ & $1.67 \mathrm{E}+02$ & $6.03 \mathrm{E}+01$ \\
\hline $\mathrm{Na}$ & $0.00 \mathrm{E}+00$ & $1.12 \mathrm{E}+02$ \\
\hline $\mathrm{Ni}$ & $3.87 \mathrm{E}+02$ & $1.10 \mathrm{E}+02$ \\
\hline $\mathrm{Si}$ & $3.42 \mathrm{E}+03$ & $2.03 \mathrm{E}+03$ \\
\hline Density $(\mathrm{g} / \mathrm{cm} 3)$ & $3.88 \mathrm{a}$ & $3.68 \mathrm{~b}$ \\
\hline
\end{tabular}

Sources: a (BSC 2003)

b MOL.20020102.0190

Table 15. Comparison of material composition of post-breach clay (20,400 years) for OCRWM analyses. The BSC analysis did not use post-breach clay.

\begin{tabular}{|c|c|}
\hline \multicolumn{2}{|c|}{ Post-Breach Clay } \\
\hline Element & $\begin{array}{c}\text { OCRWM Mass of Element after 53,241 } \\
\text { Years of Emplacement (kg) }\end{array}$ \\
\hline $\mathrm{O}$ & $2.58 \mathrm{E}+03$ \\
\hline $\mathrm{Al}$ & $1.40 \mathrm{E}+02$ \\
\hline $\mathrm{Ba}$ & $5.82 \mathrm{E}-02$ \\
\hline $\mathrm{Cr}$ & $3.25 \mathrm{E}-07$ \\
\hline $\mathrm{Fe}$ & $5.22 \mathrm{E}+03$ \\
\hline $\mathrm{Gd}$ & $1.89 \mathrm{E}-01$ \\
\hline $\mathrm{H}$ & $1.47 \mathrm{E}+01$ \\
\hline $\mathrm{P}$ & $1.94 \mathrm{E}+00$ \\
\hline $\mathrm{K}$ & $3.08 \mathrm{E}-02$ \\
\hline $\mathrm{Mn}$ & $8.26 \mathrm{E}+01$ \\
\hline $\mathrm{Mo}$ & $2.28 \mathrm{E}+00$ \\
\hline $\mathrm{S}$ & $6.41 \mathrm{E}-02$ \\
\hline $\mathrm{Si}$ & $3.80 \mathrm{E}+01$ \\
\hline $\mathrm{Ti}$ & $1.57 \mathrm{E}-01$ \\
\hline $\mathrm{U}$ & $2.17 \mathrm{E}+01$ \\
\hline Density $(\mathrm{g} / \mathrm{cm} 3)$ & 4.97 \\
\hline
\end{tabular}

Source: DOC.20041012.0006 Table 6.2

Table 16. Comparison of material composition of Dry Tuff for the BSC and OCRWM analyses.

\begin{tabular}{|c|c|c|}
\hline \multicolumn{3}{|c|}{ Dry Tuff } \\
\hline Element & $\begin{array}{c}\text { BSC } \\
\text { Composition }(\text { wt \%) }\end{array}$ & $\begin{array}{c}\text { OCRWM } \\
\text { Compositionb (wt \%) }\end{array}$ \\
\hline $\mathrm{SiO} 2$ & 76.83 & 76.29 \\
\hline $\mathrm{Al} 2 \mathrm{O} 3$ & 12.74 & 12.55 \\
\hline
\end{tabular}




\begin{tabular}{|c|c|c|}
\hline $\mathrm{FeO}$ & 0.84 & 0.14 \\
\hline $\mathrm{Fe} 2 \mathrm{O} 3$ & 0 & 0.97 \\
\hline $\mathrm{MgO}$ & 0.25 & 0.13 \\
\hline $\mathrm{CaO}$ & 0.56 & 0.5 \\
\hline $\mathrm{Na} 2 \mathrm{O}$ & 3.59 & 3.52 \\
\hline $\mathrm{K} 2 \mathrm{O}$ & 4.93 & 4.83 \\
\hline $\mathrm{TiO} 2$ & 0.1 & 0.11 \\
\hline $\mathrm{P} 2 \mathrm{O} 5$ & 0.02 & 0.05 \\
\hline $\mathrm{MnO}$ & 0.07 & 0 \\
\hline Density $\left(\mathrm{g} / \mathrm{cm}_{3}\right)$ & $2.245 \mathrm{a}$ & $2.45 \mathrm{c}$ \\
\hline
\end{tabular}

Sources: a CRWMS M\&O (2001, Attachment II spreadsheet "Tuff composition.xls").

b DTN: GS000308313211.001, file 'zz_sep_254139.txt,' row 41.

c (OCRWM 2004)

Table 17. Comparison of material composition of Ni-Gd alloy for the BSC and OCRWM analyses.

Sources: a (BSC 2003)

\begin{tabular}{|c|c|c|}
\hline \multicolumn{3}{|c|}{ Ni-Gd Alloy } \\
\hline Element & $\begin{array}{c}\text { BSC Compositiona } \\
\text { (wt \%) }\end{array}$ & $\begin{array}{c}\text { OCRWM Compositionb } \\
\text { (wt \%) }\end{array}$ \\
\hline $\mathrm{C}$ & 0 & 0.01 \\
\hline $\mathrm{N}$ & 0 & 0.01 \\
\hline $\mathrm{Si}$ & 0 & 0.08 \\
\hline $\mathrm{P}$ & 0 & 0.005 \\
\hline $\mathrm{S}$ & 0 & 0.005 \\
\hline $\mathrm{Cr}$ & 16.01 & 15.8 \\
\hline $\mathrm{Mn}$ & 0 & 0.5 \\
\hline $\mathrm{Mo}$ & 15.17 & 14.55 \\
\hline $\mathrm{Fe}$ & 0 & 1 \\
\hline $\mathrm{Ni}$ & 66.82 & 64.035 \\
\hline $\mathrm{Co}$ & 0 & 2 \\
\hline $\mathrm{O}$ & 0 & 0.005 \\
\hline $\mathrm{Gd}$ & 2 & 2 \\
\hline Density $(\mathrm{g} / \mathrm{cm} 3)$ & $8.73 \mathrm{a}$ & $8.76 \mathrm{~b}$ \\
\hline
\end{tabular}

b ASTM B 932-04, p. 1-2. 
Table 18. Material composition of borated stainless steels 304B4, 304B5, and 304B6

\begin{tabular}{|c|c|c|c|}
\hline Material & $\begin{array}{c}\text { 304B4 Compositiona } \\
\text { (wt \%) }\end{array}$ & $\begin{array}{c}\text { 304B5 Compositiona } \\
\text { (wt \%) }\end{array}$ & $\begin{array}{c}\text { 304B5 Compositiona } \\
\text { (wt \%) }\end{array}$ \\
\hline $\mathrm{Cr}$ & 19 & 19 & 19 \\
\hline $\mathrm{Ni}$ & 13.5 & 13.5 & 13.5 \\
\hline $\mathrm{B}$ & 1 & 1.25 & 1.5 \\
\hline $\mathrm{C}$ & 0.08 & 0.08 & 0.08 \\
\hline $\mathrm{Mn}$ & 2 & 2 & 2 \\
\hline $\mathrm{Fe}$ & 64.42 & 64.17 & 63.92 \\
\hline
\end{tabular}

Sources: a ASME 2001 Section II, Part A, SA-240, Table 1.

b ASTM G 1-90, Table X1.1

\subsection{BSC Evaluation}

BSC performed an evaluation in 2003 to assess the possibility of directly disposing of aluminum fuel in the Yucca Mountain Repository. The criticality section examined the ATR fuel in a $10 \mathrm{ft}$., $18 \mathrm{in}$. DOE Standardized SNF Canister surrounded by five DHLW canisters within a codisposal waste package. Three geometric scenarios were analyzed: (1) intact, (2) pre-breach, and (3) degraded. Section 2.2.1 describes the scenarios, Section 2.2.2 lists the assumptions, and section 2.2.3 summarizes the results. Researchers used Monte Carlo N-Particle Transport Code (MCNP) Version 4B2 and the ENDF/B-V continuousenergy cross section libraries to model these scenarios (CRWMS M\&O 1998).

\subsubsection{Description of Scenarios Analyzed}

The intact scenario modeled the codisposal waste package as described above in Section 2.1.1.4. The waste package was assumed to be disposed of horizontally inside the repository. Inside the horizontal waste package, DHLW canisters and the DOE Standardized SNF Canister were all assumed to be intact. The basket with intact fuels was assumed to be both dry and fully flooded to determine the effects of moderation. Dimensions of the basket are given in Section 2.1.1.2. In addition to completely dry and completely flooded cases, one case modeled the DOE Standardized SNF Canister fully as flooded and remaining waste package with DHLW glass canisters as dry. An additional case evaluated the basket material by modelling it with no gadolinium present in the $\mathrm{C} 4$ alloy.

Based on the size of each compartment in the basket, the fuel element could be rotated within the compartment. This allowed for a large number of orientations of the fuel to be evaluated. The most reactive configuration was when the fuel elements were rotated in the compartments as the outer fuel plates faced inward toward the center. This fuel configuration was used as the base case for all the prebreach scenarios and scenarios that involved variations in the void fraction. This is depicted in Figure 7. 


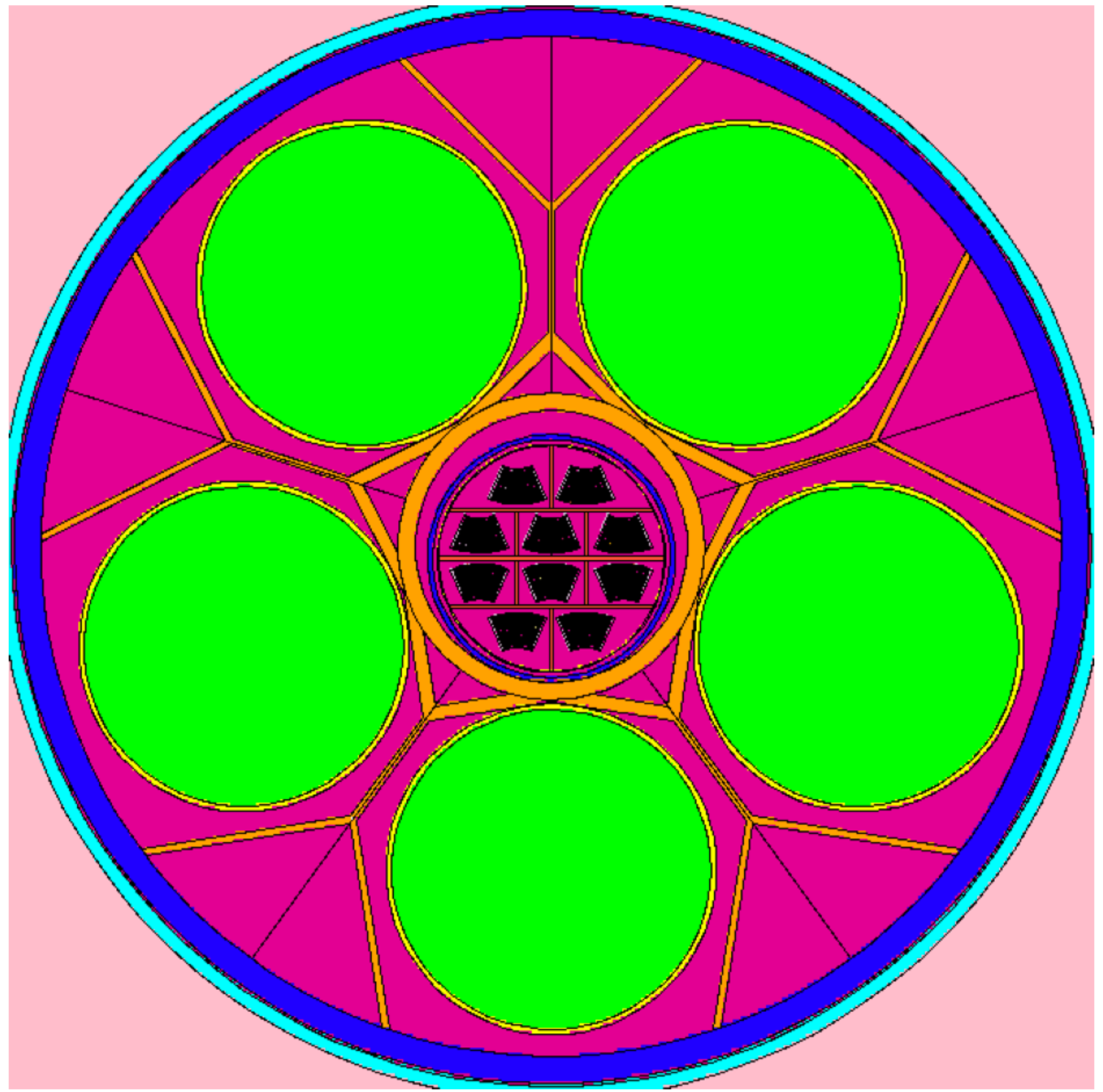

Figure 7. Intact ATR fuel rotated to its most reactive configuration.

The void fraction in the fuel matrix region of the fuel elements was varied from $0 \%$ to $12 \%$. The void fraction describes the amount of water contained in small voids within the fuel meat. This was modeled by varying the amount of oxygen and hydrogen homogenously throughout the ATR fuel meat. As the void fraction increased, more hydrogen and oxygen were added to the material, increasing the density of the material. Three cases were modeled with void fractions of $4 \%, 8 \%$, and $12 \%$, respectively. The maximum void fraction is $11 \%$, but $12 \%$ was modeled for an added layer of conservatism.

The second scenario modeled the waste package and its internals in a pre-breach configuration. This scenario assumed water had penetrated the waste package and degraded the DHLW canisters and glass. The DOE Standardized SNF Canister, the basket, and ATR fuel were still assumed to be intact. The DOE Standardized SNF Canister was positioned in the waste package surrounded by pre-breach clay and water. 
The bottom half of the waste package was modeled as pre-breach clay, while the top half was modeled as either void or water. The quantity of water in the clay was varied to determine the effects increasing water reflection had on reactivity. Additional calculations evaluated the SNF canister at various heights in the clay. Initially, the canister was assumed to be resting on the bottom of the waste package. The prebreached scenario is illustrated in Figure 8.

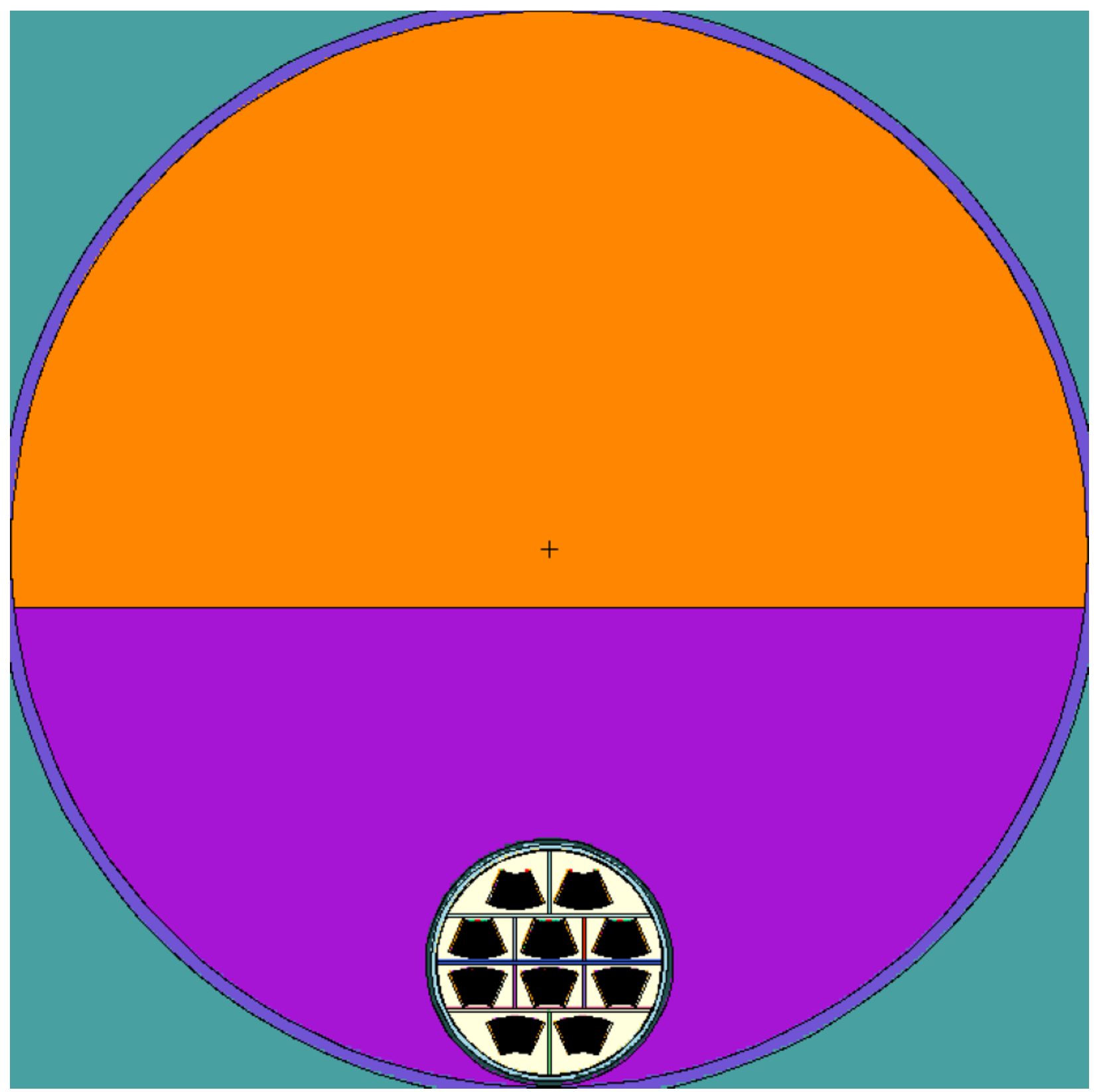

Figure 8. Intact ATR fuel surrounded by pre-breach clay.

The third scenario, degraded, was modeled by postulating that water entering the DOE Standardized SNF Canister would eventually cause the fuel inside of the canister to degrade. The internal basket was assumed to remain intact since it is resistant to corrosion. The uranium-aluminum fuel would degrade and was assumed to homogeneously mix with water. The aluminum in the fuel, when mixed with water, was 
assumed to form diaspore (AlOOH). The fuel/diaspore mixture was evaluated, with various amounts of the water inside each compartment of the basket. It was assumed that the material from each fuel element was confined to its respective storage location. The amount of aluminum and uranium was conserved in each case, with no physical movement of fissile material between basket compartments. The volumes above for each fuel region not occupied by the uranium/diaspore mixture were assumed to be filled with water. The degraded scenario is illustrated in Figure 9.

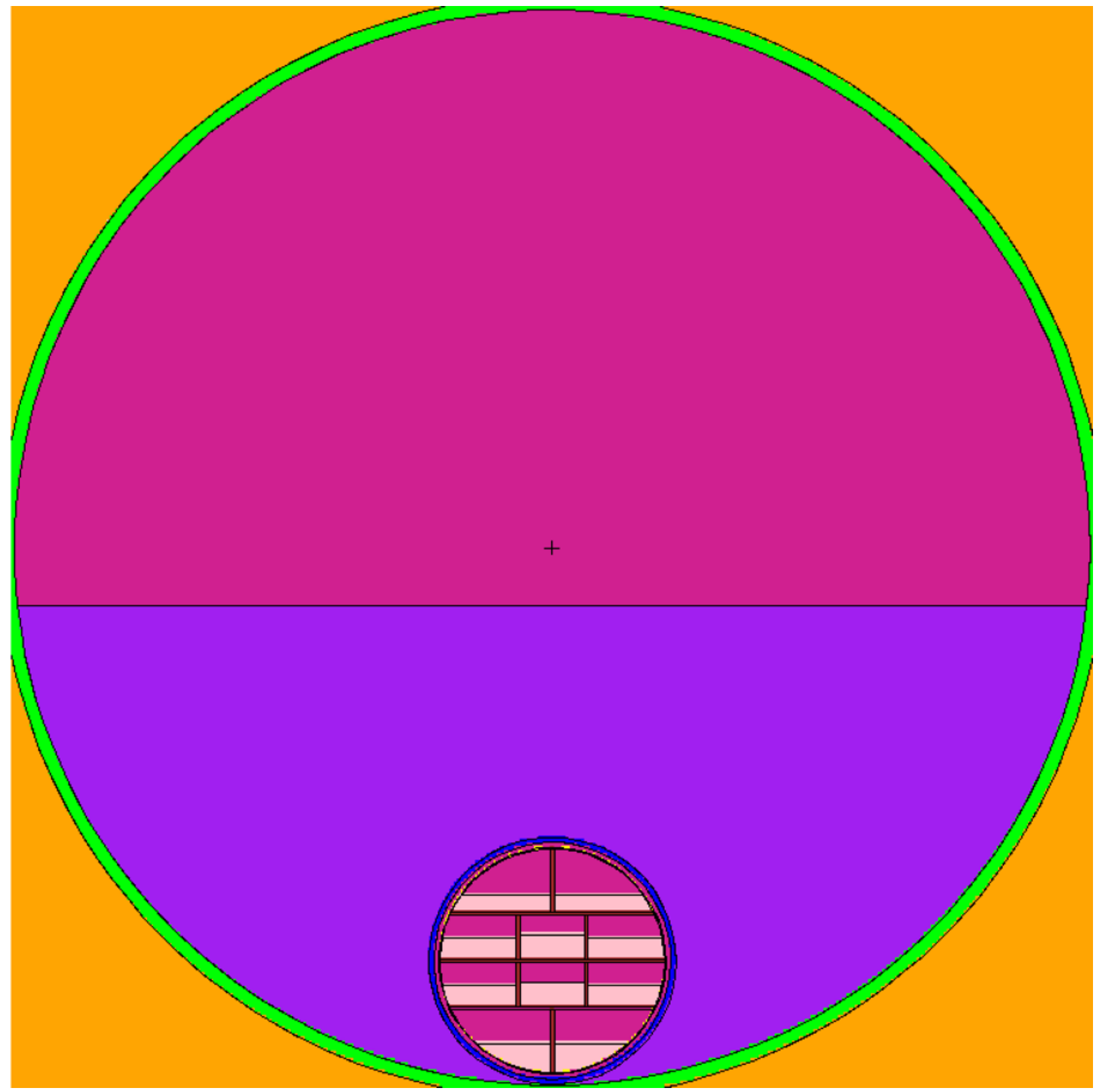

Figure 9. Degraded ATR fuel surrounded by pre-breach clay.

Because the water was assumed to enter through a small leak, the DOE Standardized SNF Canister was modeled as intact. It was positioned at the bottom of the waste package surrounded by pre-breach 
clay, which filled the entire bottom half of the waste package. The top half of the waste package was modeled filled with water.

The amount of water homogenously mixed with the diaspore and uranium varies from $0 \%$ up to a maximum of $75 \%$ in some compartments. At $0 \%$, the homogenous mixture of degraded ATR contained no water intermixed, but water was assumed to cover to fill the top of the remaining compartment. At the maximum water mixture, the material compartment was filled a mixture of water, diaspore, and uranium. There was no excess room for water to fill the void space on top of the mixture. This was modeled by increasing the amount of hydrogen and oxygen contained in the degraded mixture, increasing the volume of the mixture, and recalculating the atomic number density of the homogenously mixed material. Researchers varied the basket thickness from 0.25 in. to 0.375 in.

\subsubsection{Assumptions}

- For the degraded model's criticality calculations, it was assumed that the aluminum in the fuel meat and cladding degrades to diaspore - $\mathrm{AlOOH}$.

- ${ }_{138} \mathrm{Ba}$ cross sections were used instead of ${ }_{137} \mathrm{Ba}$ cross sections in the MCNP input, since cross sections of $137 \mathrm{Ba}$ are not available in either ENDF/B-V or ENDF/B-VI cross-section libraries.

- Beginning-of-life composition of the ATR SNF fuel was considered for this calculation.

- No burnup was modeled.

- The most reactive fissile content of $94 \mathrm{wt} \%{ }_{235} \mathrm{U}$ was used for the ATR fuel to bound the enrichment of any ATR fuel assembly.

- $\mathrm{Al}$ cross sections were used instead of $\mathrm{Zn}$ cross sections in the MCNP input, since cross sections of $\mathrm{Zn}$ are not available in the MCNP 4B2LV cross-section libraries.

\subsubsection{Summarized Results}

Models of the codisposal waste package containing an SNF canister with 20 ATR fuel elements were evaluated in this analysis. The fuel was modeled in three scenarios. The first scenario evaluated an intact waste package, which was fully flooded. The waste package was determined to be sub-critical, provided the basket inside the SNF canister is constructed out of a C4 alloy with a plate thickness of 0.25 in. (6.35 $\mathrm{mm}$ ). The second stage evaluated a waste package with a homogenized mixture of clay and water surrounding an SNF canister. The calculated results for these cases did not vary significantly from the intact models. The third stage of degradation evaluated degraded fuel in an intact basket at the bottom of the waste package surrounded by pre-breach clay. Water in the SNF canister completely degraded the fuel into a homogeneous mixture of uranium/water/diaspore. For the most reactive mixture, the calculated $\mathrm{k} \_$eff $+2 \sigma$ exceeds 0.93 with a 0.25 -inch thick $(6.35 \mathrm{~mm})$ basket. If the basket plate thickness is increased to 0.375 inches $(9.525 \mathrm{~mm})$, the calculated k_eff is 0.91 . Therefore, BSC recommended a 0.375 -inchthick $(9.525 \mathrm{~mm})$ basket be used.

\subsection{OCRWM Evaluation}

OCRWM performed an evaluation in 2004 to further assess the possibility of directly disposing of aluminum fuel in the Yucca Mountain repository. The report evaluated ATR fuel in a DOE Standardized SNF Canister surrounded by five DHLW canisters within a codisposal waste package. Four geometric scenarios were analyzed: (1) intact, (2) degraded fuel inside DOE Standardized SNF Canister, (3) degraded components outside a DOE Standardized SNF Canister, and (4) completely degraded. In addition to different geometries, this analysis included the use of aluminum shot interspersed with gadolinium within the canister. Section 2.3.1 describes the scenarios, Section 2.3.2 lists the assumptions, 
and Section 2.3.3 summarizes the results. Originally, researchers used MCNP Version 4B2 and the ENDF/B-V continuous-energy cross-section libraries.

\subsubsection{Description of Scenarios}

The intact scenario modeled the codisposal waste package as described above in Section 2.1.1.4. The waste package was assumed to be disposed of horizontally inside the repository. Inside the horizontal waste package, DHLW canisters and the DOE Standardized SNF Canister were all assumed to be intact. All canister internals were assumed to be intact. The basket with intact fuels was modeled both dry and fully flooded to determine the effects of moderation. Unless noted otherwise, the unoccupied spaces inside the DOE Standard SNF Canister and waste package were modeled as filled with water. Variations of the intact configurations were examined to identify the configuration that resulted in the highest calculated k_eff value within the range of possible conditions. The fuel was settled in gravitationally stable positions in each compartment. Additional cases varied the amount of water homogenously mixed in the void spaces of the fuel meat. Other cases examined partial flooding of the waste package, rotations of fuel elements, rotation of the DOE Standard SNF Canister, and waste package boundary conditions. Finally, the effect of coupling of the most important variations was investigated to identify the bounding cases for the intact configurations. A separate case was also run to analyze the effectiveness of the design solution regarding introduction of additional $\mathrm{Gd}$ as a neutron absorber distributed within a moderator displacer ( $\mathrm{Al}$ shot). The intact geometry is illustrated in Figure 10. 


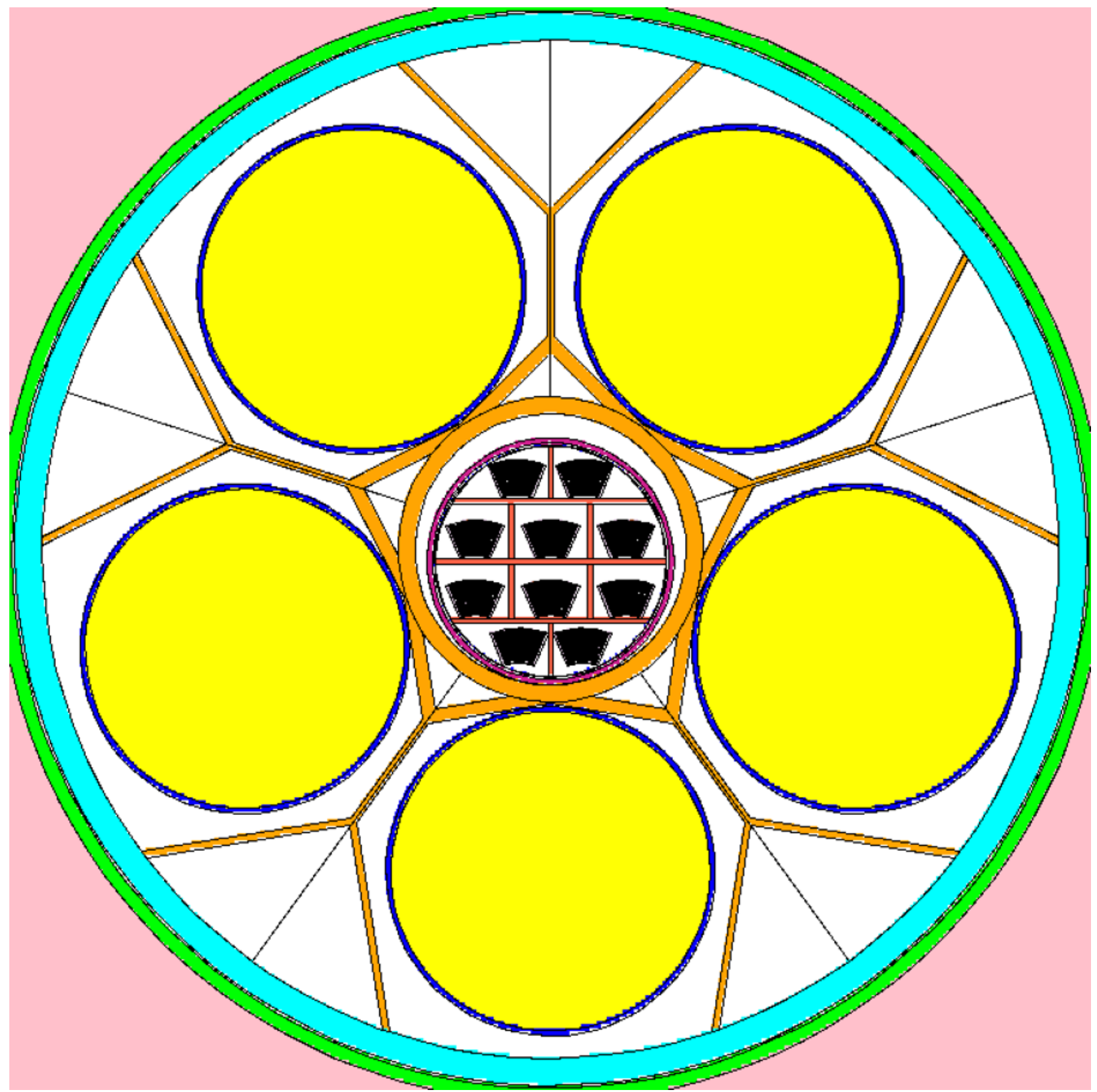

Figure 10. Intact ATR fuel surrounded by an intact DOE Standardized SNF Canister and intact DHLW canisters.

The second scenario evaluated was the degraded ATR fuel inside the intact DOE Standardized SNF Canister with intact DHLW canisters. This occurred if the canister was breached shortly after the breach and flooding of the waste package. The basket with intact fuels was modeled both dry and fully flooded to determine the effects of moderation. The cases were examined for both partially degraded and completely degraded fuel placed in the basket compartments of the DOE Standardized SNF Canister. The aluminum was assumed to degrade to gibbsite $\left[\mathrm{Al}(\mathrm{OH})_{3}\right]$ and uranium to schoepite $\left[\left(\mathrm{UO}_{2}\right)_{8} \mathrm{O}_{2}(\mathrm{OH})_{12 .}{ }_{2}\left(\mathrm{H}_{2} \mathrm{O}\right)\right]$. The degraded materials expanded and filled the available space inside the canister. The basket material containing Gd did not degrade and stayed in place. The degradation products were considered 
homogeneously mixed and formed with various values for internal porosity. The amount of water filling this internal void was varied. The expansion of the degradation products was limited by the space available in each compartment. Another case allowed expansion of the degradation material in all space available in the canister, including the space occupied by the inner sleeve and the gap between the sleeve and canister. The degraded ATR fuel surrounded by intact DHLW canisters is illustrated in Figure 11.

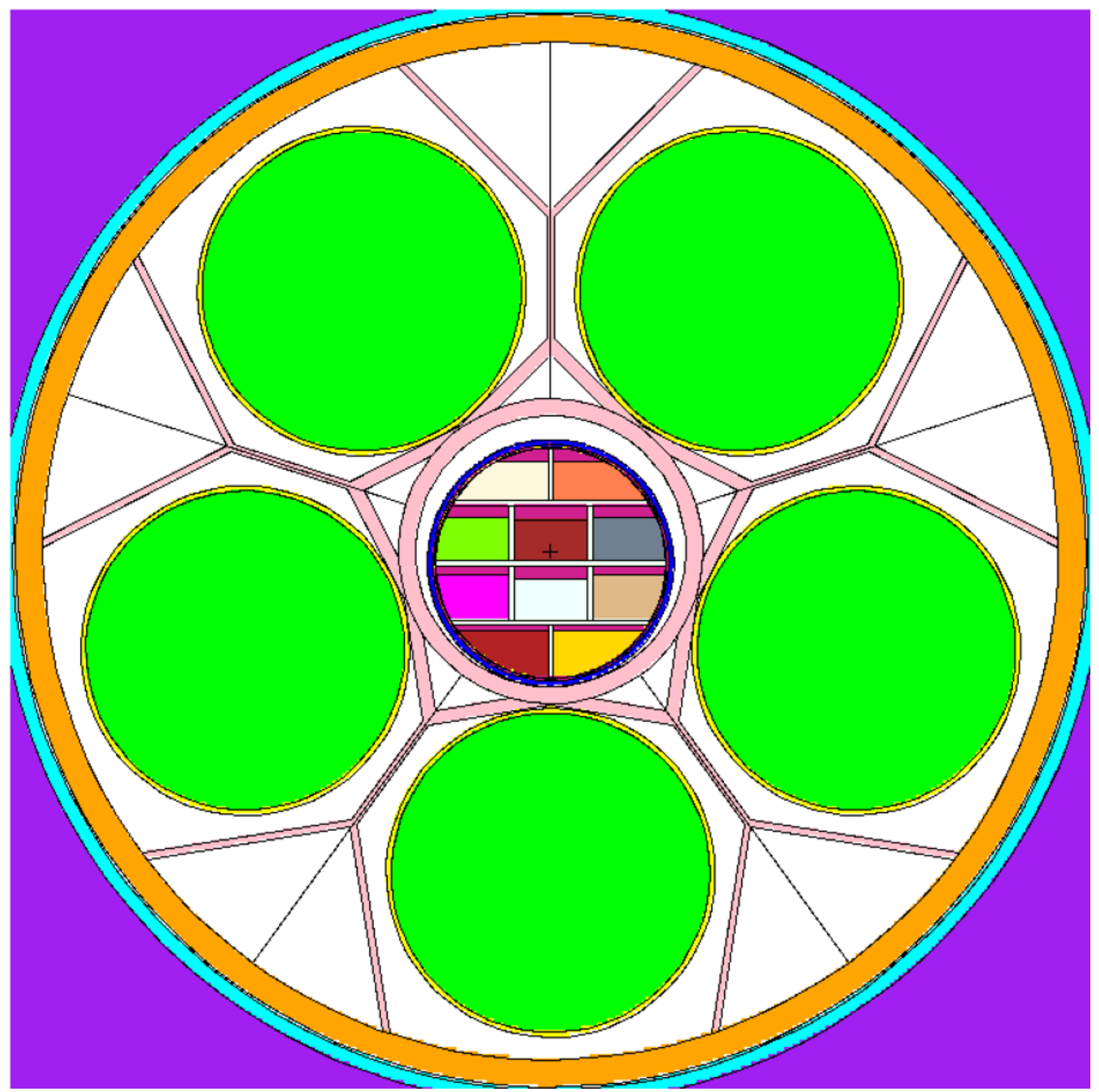

Figure 11. Degraded ATR fuel surrounded by intact DHLW canisters.

The third scenario evaluated was intact or degraded ATR fuel inside the DOE Standardized SNF Canister surrounded by pre-breach clay in the bottom half of the waste package. The top half of the waste package was assumed to be void or water. This occurred if the DOE SNF canister breached long after the 
breaching of the waste package, which allowed the waste package internals to degrade and form a claylike material (pre-breach clay). At some point in time, the canister would breach, allowing internal fuel to degrade as presented in the previous scenario. The configurations analyzed in this report include having the canister placed in various positions inside the pre-breach clay (mixed with various fractions of water). The spent nuclear fuel inside the canister was modeled intact or in various stages of degradation. The degraded ATR fuel surrounded by pre-breach clay is illustrated in Figure 12.

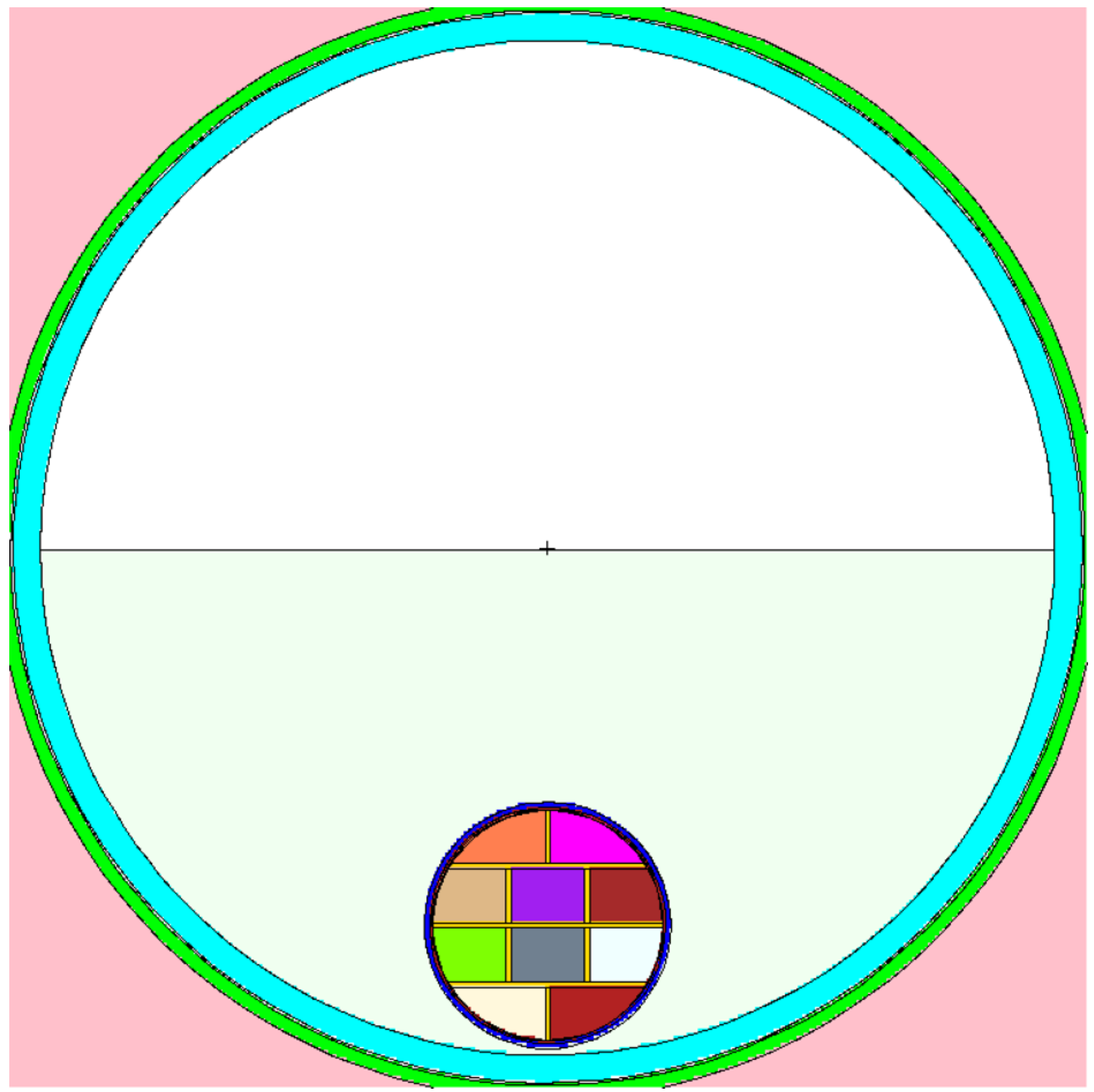

Figure 12. Degraded ATR fuel in an intact DOE Standardized SNF Canister surrounded by pre-breach clay.

The final scenario evaluated was completely degraded internals. Everything inside the waste package was assumed to be degraded. 
Geochemistry calculations have produced compositions for the clay-like materials that can be obtained by applying both scenarios. For the purpose of the [this] calculation, a scenario that postulates degradation of the DOE SNF canister after degradation of all other waste package internals has been investigated. This scenario preserves all fissile material that is finally settled in a layer at the bottom of the waste package. (OCRWM 2004)

The calculation considered a mixture of schoepite, gibbsite, and gadolinium phosphate placed in a layer at the bottom of the waste package. The layer was covered with a mixture of pre-breach clay and water. All other components of the DOE Standardized SNF Canister were neglected (including basket structure containing $\mathrm{Gd}$ ). This scenario also encompassed configurations that could result if the degraded fuel was displaced from the canister and accumulated at the bottom of the waste package. The composition of the layers was varied, considering that various fractions of the degraded materials were leached from the waste package. The completely degraded geometry is illustrated in Figure 13. 


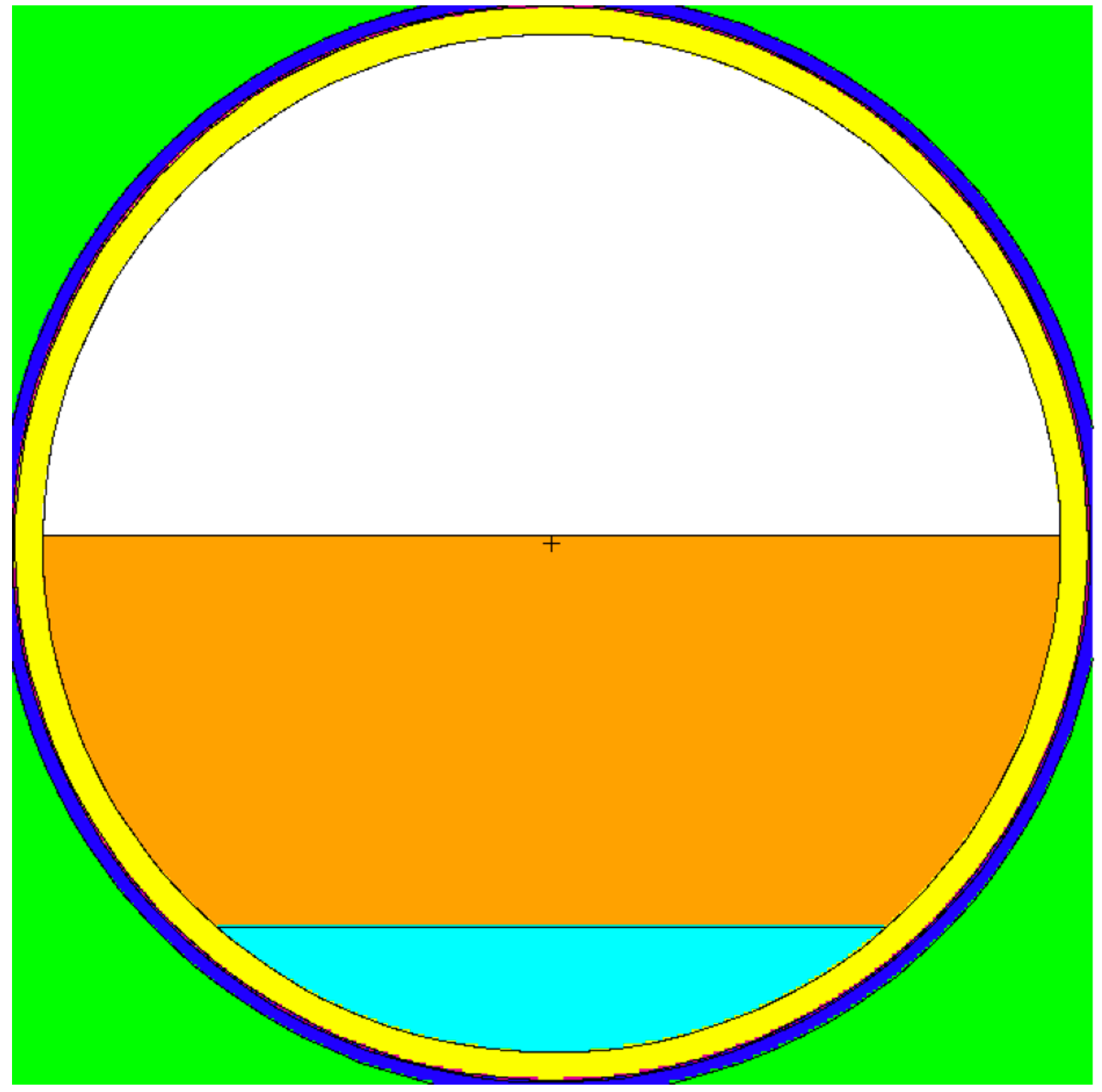

Figure 13. Completely degraded waste package internals with the degraded DOE Standardized SNF Canister and its internals on the bottom, clay in the middle, and water on top.

\subsubsection{Assumptions}

- "For the degraded mode criticality calculations, it is assumed that the aluminum in the fuel meat and cladding degrades to gibbsite - $\mathrm{Al}(\mathrm{OH})_{3}$ rather than diaspore - AlOOH." (OCRWM 2004)

- "138Ba cross sections are used instead of $137 \mathrm{Ba}$ cross sections in the MCNP input since the cross sections of $137 \mathrm{Ba}$ are not available in either ENDF/B-V or ENDF/B-VI cross section libraries." (OCRWM 2004) 
- "Beginning of life (BOL) composition of the ATR SNF fuel is considered in the present calculation and no credit is taken for the initial boron neutron absorber present in the fuel." (OCRWM 2004)

- "The most reactive fissile content of $94 \mathrm{wt} \%{ }_{235} \mathrm{U}$ is used for the ATR fuel to bound the enrichment of any ATR fuel assembly." (OCRWM 2004)

- "For the degraded configurations, the degradation products (gibbsite, schoepite) are assumed to form with void occupying $30 \%$ or more of their volume. The void can be filled with water and/or remain as void." (OCRWM 2004)

- "[Aluminum] cross sections are used instead of $\mathrm{Zn}$ cross sections in the MCNP input since the cross sections of $\mathrm{Zn}$ are not available in the MCNP 4B2LV cross-section libraries." (OCRWM 2004)

- "A void fraction of 0.4667 is assumed for the [aluminum] fill material [aluminum] shot mixed with gadolinium phosphate." (OCRWM 2004)

- "It is assumed that the volume of the aluminum and gadolinium phosphate is conserved when mixed." (OCRWM 2004)

\subsubsection{Summarized Results}

For the intact geometric scenario, repositioning of ATR elements or rotation of the DOE Standardized SNF Canister had almost insignificant effects. The flooded configurations were under-moderated. The most significant effect on the reactivity of the system was produced by changing the boundary conditions outside the canister (partial flooding) and by removing or adding neutron absorber.

In the second scenario, in which the internals of the DOE Standardized SNF Canister degrade first, the k_eff of the system slowly increased with degradation of the cladding and expansion of the degraded materials. The results showed that by degrading the fuel elements to a mixture of schoepite, gibbsite, and void filled with water, the reactivity of the system increased significantly. All configurations investigated of the system were under-moderated. The highest k_eff $+2 \sigma(0.9993)$ was obtained for a system that had a degraded mixture that completely filled the space inside the canister; the canister, including the sleeve, was filled with water, and was surrounded by a dry intact geometry of the waste package. This value was above the upper criticality limit of 0.93 , so additional poison was investigated. A mixture of aluminum shot with gadolinium phosphate was intermixed within the canister. Supplementing the basket with the Gd shot significantly reduced the k_eff well below the upper criticality limit of 0.93 . A few additional cases were run with the amount of Gd reduced to half to simulate the hypothetical effect of separation of the neutron absorber. The k_eff increased by more than $25 \%$, but was still well below the upper criticality limit.

The third scenario with an intact DOE Standardized SNF Canister surrounded by pre-breach clay was significantly under the upper criticality limit since the Gd shot was added. The fourth scenario with all internals of the waste package completely degraded also had a k_eff significantly under the upper criticality limit. Neither of these scenarios was calculated without the Gd shot.

\subsection{BSC vs. OCRWM Comparisons}

Both evaluations used 0.93 as the upper critical limit for k_eff. The BSC evaluation was not able to demonstrate sub-criticality with a basket thickness of 0.25 inches, but increasing the thickness of the basket to 0.375 inches would maintain sub-criticality of ATR fuel in the Yucca Mountain repository. The OCRWM evaluation was not able to demonstrate sub-criticality with a basket thickness of 0.375 inches. OCRWM determined that the best way to reduce the calculated k_eff was to use moderator-displacing 
neutron absorbing beads. With the addition of the Gd shot, OCRWM was able to demonstrate subcriticality for ATR fuel in the Yucca Mountain repository.

Aside from the OCRWM evaluation being more conservative that the BSC evaluation in material compositions, the main difference between the two evaluations was the assumption for the degraded ATR material. BSC assumed the ATR material degraded into a diaspore/uranium/water mixture. The material would be conserved but would not significantly expand. OCRWM assumed the ATR material degraded into a homogeneous mixture of gibbsite and schoepite. Gibbsite has a higher moderation factor than diaspore.

The baskets were another difference in the two evaluations. BSC's basket had a wider width and shorter height than the basket OCRWM used. These differences in dimension result in a smaller basket volume in the BSC evaluation than in the OCRWM evaluation, as shown in Table 4.

OCRWM evaluated two additional geometric scenarios with the DHLW canister intact and the entire internals of the waste package degraded. The former scenario had the highest k_eff calculated in the evaluation. The latter scenario was only calculated using the addition of Gd shot.

\section{NEUTRON-ABSORBING MATERIALS}

This section examines the Ni-Cr-Mo-Gd Alloy and borated stainless steel as neutron-absorbing materials used in the DOE Standardized SNF Canister. While other materials, such as hafnium and borated aluminum, have been used as neutron-absorbing materials in other applications, they will not be discussed in this analysis. More in-depth discussion on the history of neutron-absorbing materials can be found in "Neutron Absorber Considerations for the DOE Standardized Canister" (Petersen 2019b).

\subsection{Ni-Cr-Mo-Gd Alloy}

The ASTM accepted a new corrosion-resistant, nickel-chromium-molybdenum alloy containing gadolinium as ASTM standard B 932-04 (UNS N06464) (ASTM 2004). In 2005, the new material was approved for ASME Section III, Division 3 applications as Code Case N-728. This material came to be known as the Advanced Neutron Absorber (ANA) (ASME 2005). Preliminary testing appeared to indicate the alloy has acceptable welding properties, and preliminary corrosion tests also produced results indicating favorable properties to ensure retention of gadolinium within the alloy (Mizia 2004).

ANA was subject to a number of tests because of its inclusion in the Yucca Mountain License Application. Researchers performed criticality experiments, which are documented in the "International Handbook of Evaluated Criticality Safety Benchmark Experiments" (IHECSBE 2004) and validated models by confirming natural gadolinium in the ANA will absorb neutrons consistent with known neutron cross sections and models (Wachs 2007). Researchers desired ANA to be weldable in order to be fabricated into a DOE Standardized SNF Canister basket. A welding development program was created in 2007 in an attempt to develop an ASME code case for welding of ANA. The measurements required for a welded code case include mechanical properties (ultimate strength, yield strength, total elongation, and reduction of area), Charpy impact tests (impact energy and lateral expansions), and fracture toughness (Hurt 2007). The ASME code case for welded construction of ANA was never realized, as funding for completing the code case was discontinued.

\subsection{Borated Stainless Steels}

There are eight types of borated stainless steels (304B to 304B7) in ASTM A887 that define the base alloy chemistry; the boron concentrations range from 0.2 to $2.25 \mathrm{wt} \%$. There are two grades (A and B) defined. The minimum material requirements for each grade are controlled by mechanical properties. This 
results in 16 distinct alloy grades and compositions. These requirements define the alloy processing, where Grade A alloys are powder- metallurgy products and Grade B alloys are ingot-metallurgy products. Increasing the number attached to the borated stainless steel increases the concentration of boron (e.g., 304B5 has a higher concentration of boron than 304B4).

For this evaluation, three different Grade A materials were used (304B4, 304B5, and 304B6). 304B4 has a boron concentration between 1 and 1.24\%.304B5 has a boron concentration between 1.25 and $1.49 \% .304 \mathrm{~B} 6$ has a boron concentration between 1.50 and 1.74\%. 304B 4 was analyzed in this evaluation at two different boron concentrations (1.00 and 1.17\%). The composition of these materials used in this evaluation are listed in Table 19 below. Boron concentrations were picked at the lowest end to add conservatisms. The percentage of $11 \mathrm{~B}$ was assumed to be $80 \%$, while the percentage of $10 \mathrm{~B}$ was assumed to be $20 \%$.

Table 19. Boron compositions for 304B4, 304B5, and 304B6 used in this analysis.

\begin{tabular}{|c|c|c|c|c|}
\hline Element & $\begin{array}{c}\text { 304B4 1.00\% B } \\
\text { Compositiona (wt \%) }\end{array}$ & $\begin{array}{c}\text { 304B4 1.17\% B } \\
\text { Compositiona (wt \%) }\end{array}$ & $\begin{array}{c}\text { 304B5 1.25\% B } \\
\text { Compositiona (wt \%) }\end{array}$ & $\begin{array}{c}\text { 304B6 1.50\% B } \\
\text { Compositiona (wt \%) }\end{array}$ \\
\hline $\mathrm{Cr}$ & 19 & 19.46 & 19 & 19 \\
\hline $\mathrm{Ni}$ & 13.5 & 13.39 & 13.5 & 13.5 \\
\hline $\mathrm{B}$ & 1 & 1.17 & 1.25 & 1.5 \\
\hline $\mathrm{C}$ & 0.08 & 0.05 & 0.08 & 0.08 \\
\hline $\mathrm{Mn}$ & 2 & 1.91 & 2 & 2 \\
\hline $\mathrm{Fe}$ & 64.42 & 64.02 & 64.17 & 63.92 \\
\hline
\end{tabular}

a (Mizia 2011)

b (Lister 2008)

Corrosivity of the basket material has been an important factor in the selection process of the basket material. Initial reports examined the A978 alloy of borated stainless steel. While these tests did not satisfy the corrosion objectives of the basket material to corrode at a similar rate to stainless steel, 304B4, manufactured to a Grade A qualification, has a corrosion rate of $80 \mathrm{~nm} / \mathrm{yr}$. 304B5 has a corrosion rate of $600 \mathrm{~nm} / \mathrm{yr}$ (He 2011). Taking two sides of corrosion into account, a basket fabricated from 304B4 would corrode $0.16 \mathrm{~cm}$ in 10,000 years, and a basket fabricated from 304B5 would corrode $1.2 \mathrm{~cm}$ in 10,000 years. A corrosion rate for 304B6 was not validated in the same report, but one report puts the average corrosion rate of 304B6 at $464 \pm 100 \mathrm{~nm} / \mathrm{yr}$ (Lister 2008). In addition, welding the borated stainless steel decreases the material's ability to resist corrosion (Kumar 2014) Table 20 gives the corrosion rates of 304B4 and 304B5.

Table 20. Comparison of corrosion rates of borated stainless steel.

\begin{tabular}{|l|c|c|}
\cline { 2 - 3 } \multicolumn{1}{c|}{} & $\mathbf{3 0 4 B 4}(\mathbf{1 . 0 4 \%} \mathbf{B})$ & $\mathbf{3 0 4 B 5}(\mathbf{1 . 3 4 \%} \mathbf{B})$ \\
\hline Maximum Corrosion Rate & $80 \mathrm{~nm} / \mathrm{yra}$ & $600 \mathrm{~nm} / \mathrm{yra}$ \\
\hline Thickness Degraded After 10,000 & $0.16 \mathrm{~cm}$ & $1.2 \mathrm{~cm}$ \\
\hline
\end{tabular}

a Additional analyses in support of the Standardized Transportation, Aging, and Disposal Canister summarized a number of corrosion studies on borated stainless steel (ORNL 2015). Some values were higher than the maximum corrosion rates presented in this table. The tests to determine theses rates all predated the tests used in He's analysis (He 2011). 


\subsection{Neutron-Absorbing Shot}

In addition to the basket material, the OCRWM evaluation included additional neutron absorbers within the DOE Standardized SNF Canister. The proposed packaging strategy included neutron-absorbing shot/beads interstitial throughout the basket. The shot provided additional neutron absorber to the package and excluded moderator from the package (Taylor 2004). The proposed shot would be composed of iron or aluminum with gadolinium interspersed (DOE 2008).

\section{CASE DESCRIPTIONS}

This section describes the geometry and assumptions used in this criticality evaluation. Section 4.1 describes the differences between the BSC and OCRWM evaluations and performs a basic sensitivity analysis to determine the most important differences. Section 4.2 replaces the ANA in the BSC evaluation with 304B4 (1.00\%). Since the BSC study had significantly lower k_eff values than the OCRWM evaluation, only one borated stainless steel was selected as a representative. It also describes a geometric flaw in the BSC evaluation and performs a correction. Section 4.3 replaces the ANA in the OCRWM evaluation with 304B4 (1.00\% and 1.17\%). Section 4.4 includes additional analyses that increases the basket thickness from 0.375 to 0.400 inches and replaces the ANA with 304B5 (1.25\%) and 304 B6 (1.50\%). Each of these analyses uses MCNP version 6.2 (Werner 2018) and the ENDF/B-V continuousenergy cross-section libraries.

\subsection{BSC vs. OCRWM Sensitivity Evaluation}

This analysis attempted to pick a comparative case from both the BSC and OCRWM evaluation to assess the impact of changing certain variables. The BSC case used for this analysis was completely degraded fuel in an intact DOE Standardized SNF Canister within the waste package. The fuel degraded into a homogeneous mixture of uranium/water/diaspore. The basket made from the ANA had not degraded. The DHLW canisters had already degraded into pre-breach clay, so the canister sits at the bottom of the waste package. The water volume fraction within the compartments of degraded fuel was 0.3. The components and values for this analysis can be found in Section 2. The BSC name for this case is “degraded_wvf3b.o," and the k_eff was calculated as 0.6759. Figure 14 illustrates this case. 


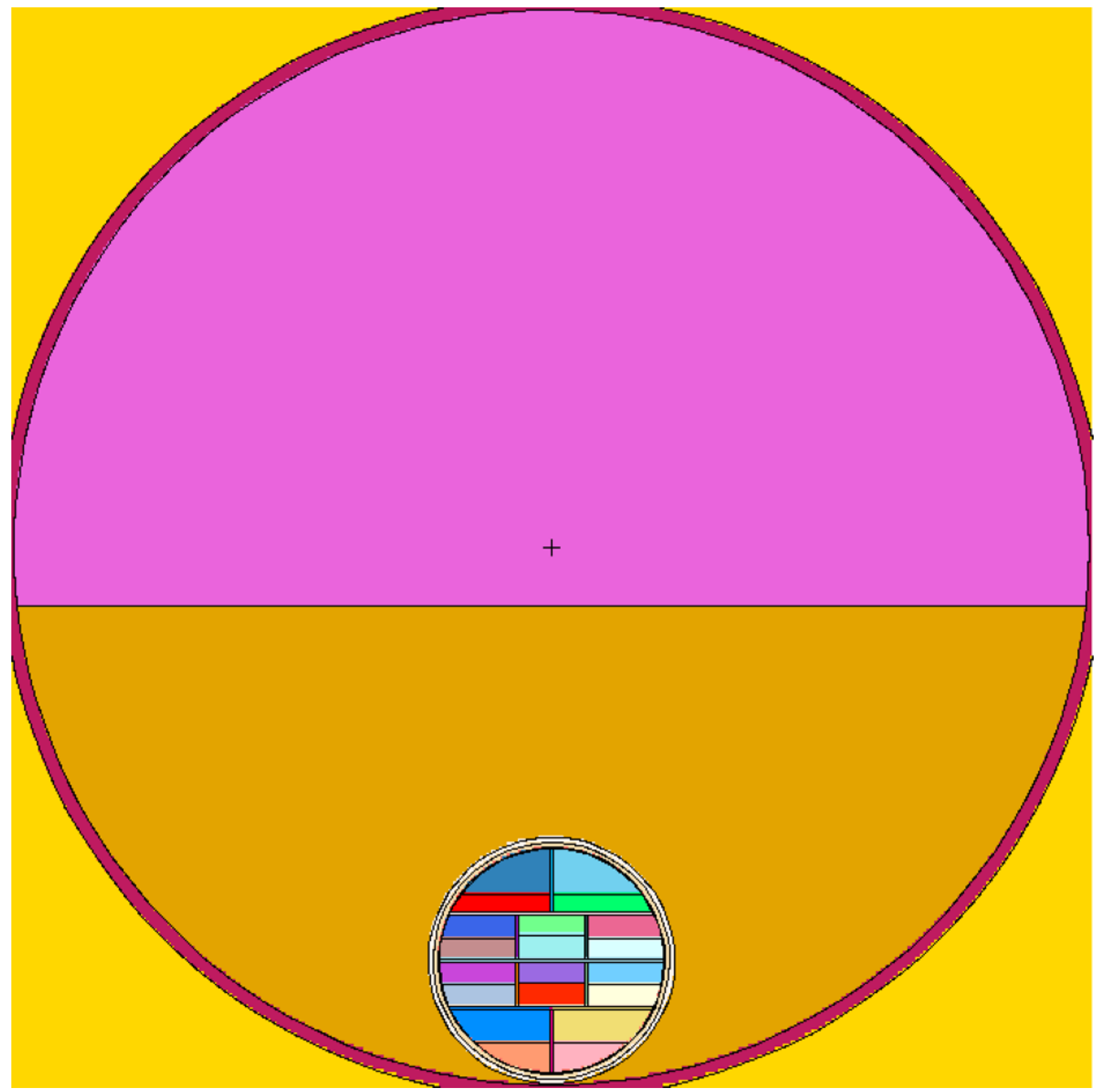

Figure 14. Degraded fuel in an intact DOE Standardized SNF Canister surrounded by pre-breach clay.

The OCRWM case used for this analysis had degraded fuel in an intact DOE Standardized SNF Canister within the waste package. The fuel degraded into a homogeneous mixture of gibbsite and schoepite. The degraded materials expanded and quickly filled the available space inside the canister. The basket made from the ANA had not degraded. The DHLW canisters had not degraded, so the DOE Standardized SNF Canister sat in the middle of the waste package surrounded by the intact DHLW canisters. The void fraction within the mixture was 0.3 . Figure 15 illustrates this case. The components and values for this analysis can be found in Section 2. The OCRWM name for this case is "atr_pdeg_tot_30wet," and the k_eff was calculated as 0.9521 . 


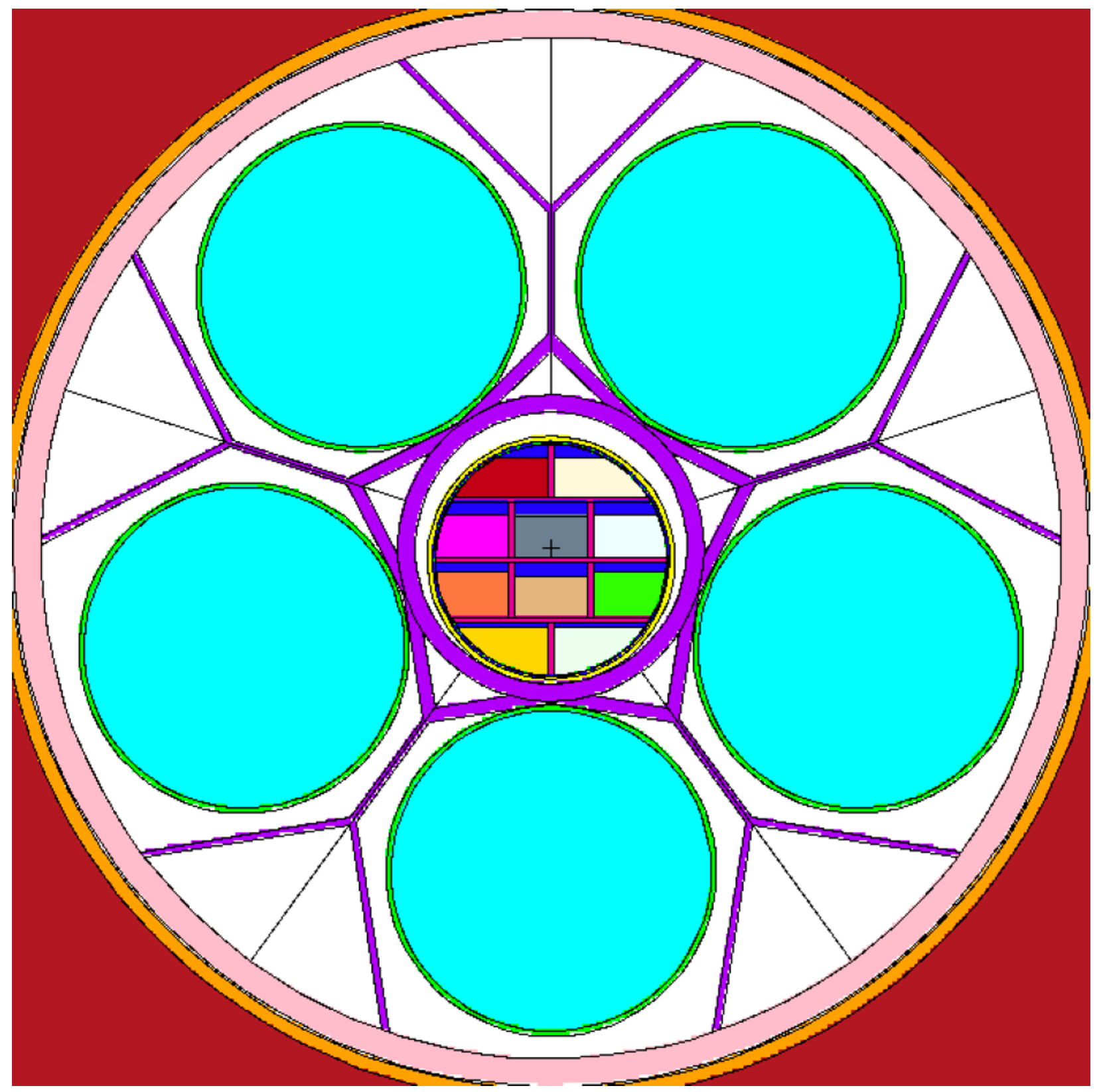

Figure 15. Degraded fuel in an intact DOE Standardized SNF Canister surrounded by intact DHLW canisters.

The following changes were performed on the BSC case using values obtained from the OCRWM case. Results are in Section 5.1

1. Changed the degraded ATR elements into a gibbsite schoepite mixture. Calculated the volumetric expansion of the materials in order to get the correct height of the new material.

2. Changed the position of the DOE Standardized SNF Canister to be situated in the middle of the five intact DHLW canisters from being positioned at the bottom of the waste package surrounded by prebreached clay.

3. Combination of cases 1 and 2 . 
4. Changed the pre-breach clay composition to match that of the OCRWM evaluation.

5. Combination of cases 1 and 4 .

6. Changed the surrounding tuff composition to match that of the OCRWM evaluation.

7. Combination of cases 1 and 6.

8. Combination of cases 4 and 6 .

9. Combination of cases 7 and 8 .

10. Combination of cases 3 and 7.

11. Changed ANA composition to match that of the OCRWM evaluation.

12. Changed carbon steel composition to match that of the OCRWM evaluation.

13. Changed stainless steel to composition of the OCRWM evaluation.

14. Combination of cases 11,12 and 13 .

15. Combination of cases 1 and 14.

16. Combination of cases 3 and 15.

17. Changed the dimensions to match OCRWM and case 1.

18. Combination of cases 17 and 3.

19. Combination of cases 14 and 18.

20. Change the criticality source definition to match OCRWM evaluation and case 2.

21. Combination of cases 19 and 20.

\subsection{Comparing ANA and Borated Stainless Steel in BSC's Evaluation}

This section describes the substitution of borated stainless steel (304B4 1.00\%) for ANA. The intact scenario modeled the codisposal waste package as described above in Section 2.1.1.1 using MCNP version 6.2 (Werner 2018) and the ENDF/B-V continuous-energy cross-section libraries. A diagram of the model is shown in Figure 16. The waste package will be disposed of horizontally inside the repository. The basket with intact fuels was modeled both dry and fully flooded to determine the effects of moderation. Dimensions of the basket are given in Section 2.1.1.3. Based on the size of each compartment in the basket, the fuel element may be arranged in a variety of ways. The basket material was changed from ANA to 304B4. The basket was also modeled as stainless steel. The void fraction in the fuel matrix region of the fuel elements may vary from 0 to 11 percent. Three cases were modeled with a void fraction of $4 \%, 8 \%$, and $12 \%$. (It is not physically possible to go past $11 \%$ void fraction, but $12 \%$ is used as a bound.) The pre-breach scenarios with borated stainless steel were not evaluated because they were not demonstrably different than the intact scenarios. 


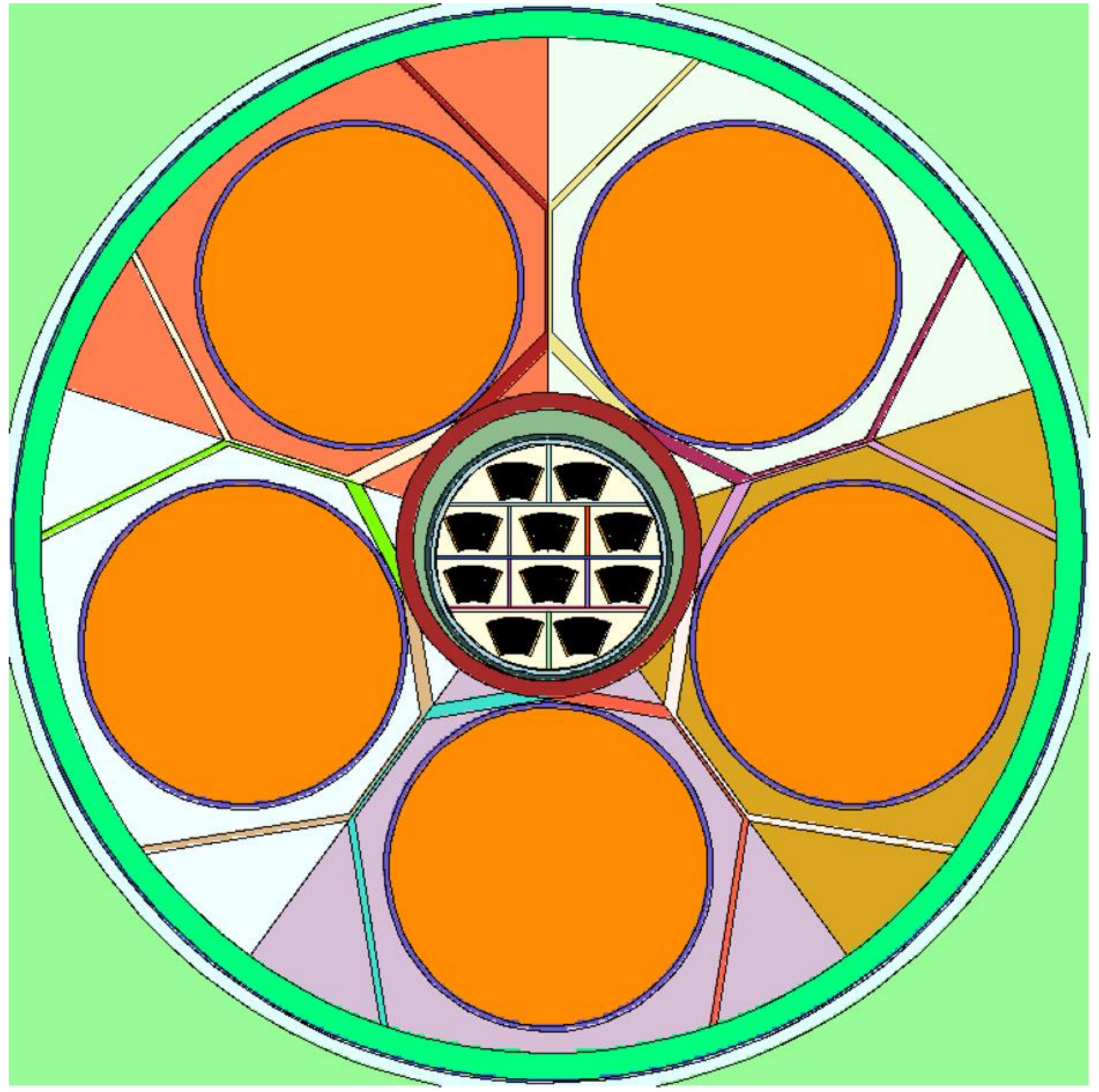

Figure 16. Intact ATR fuel in a codisposal waste package.

The degraded scenario was modeled by postulating that water entering the SNF canister would eventually cause the fuel inside of the canister to degrade. The internal basket should remain intact since it is resistant to corrosion. The uranium-aluminum fuel would degrade and was assumed to homogeneously mix with water. The DOE Standardized SNF Canister was located in the bottom of the waste package and surrounded by degraded DHLW canisters (clay). The aluminum in the fuel, when mixed with water, was assumed to form diaspore $(\mathrm{AlOOH})$. The fuel/diaspore mixture was evaluated with various amounts of the water inside each compartment of the basket. It was assumed that the material from each fuel element was confined to its respective storage location. The amount of aluminum and uranium was conserved in each case with no physical movement of fissile material between basket compartments. The water volume mixed with the fuel varied between 0 and $75 \%$. There are no water volume fractions above $75 \%$ because it represents an impossibility. The volumes above for each fuel 
region not occupied by the uranium/diaspore mixture were assumed to be filled with water. Figure 17 displays the modeled degraded scenario.

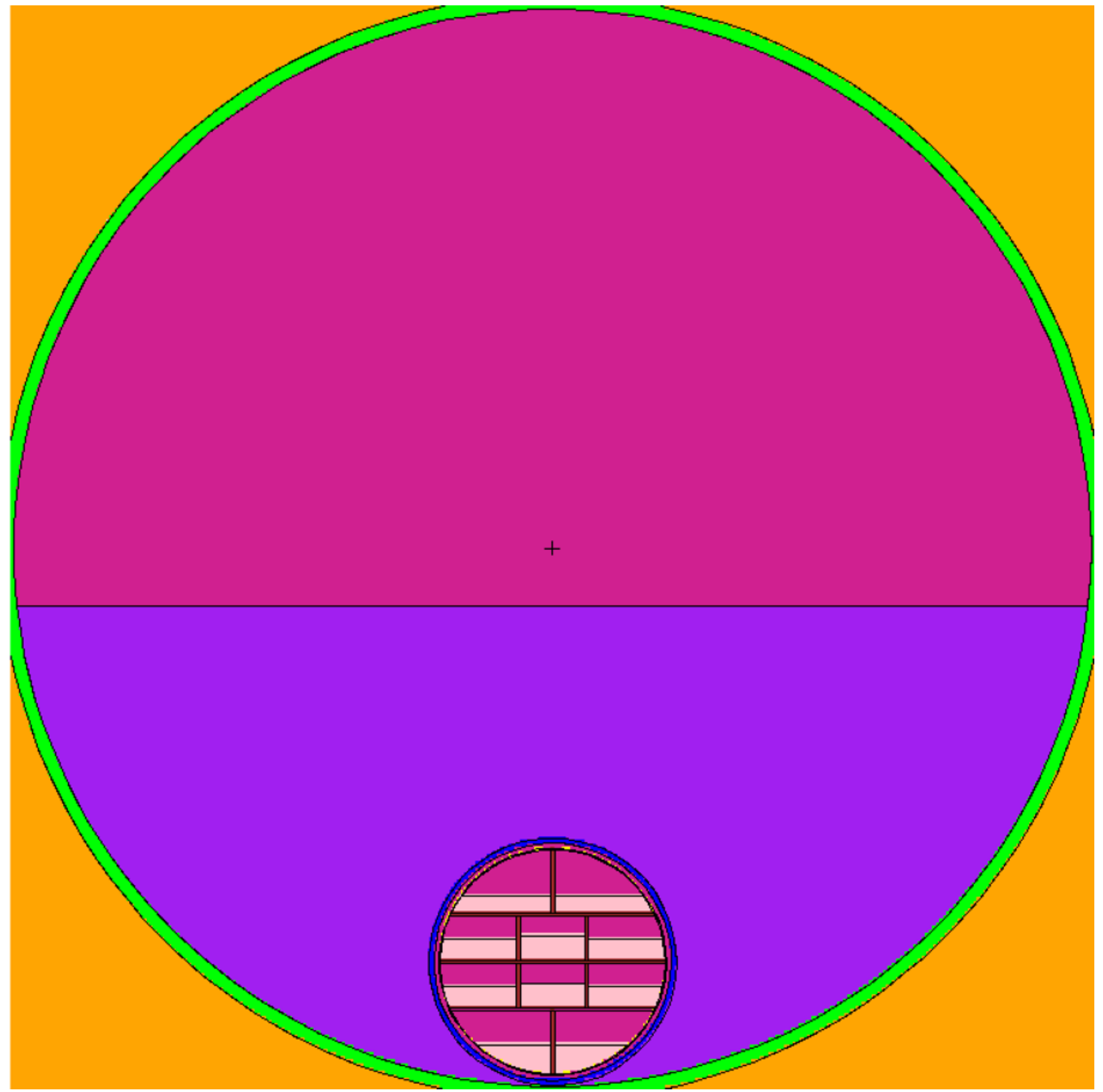

Figure 17. Degraded ATR fuel surrounded by pre-breach clay.

A slight modeling error was found when running the scenarios using MCNP6.2, which allowed the dished head on the DOE Standardized SNF Canister to slide across a boundary in the codisposal waste package. This modeling error was fixed, and the results of the differing cases are included. Results from substituting 304B4 (1.00\%) for ANA as the basket material are in Section 5.2. 


\subsection{Comparing ANA and Borated Stainless Steel in OCRWM's Evaluation}

This section describes the substitution of borated stainless steel (304B4 1.00\% and 1.17\%) for ANA in the OCRWM evaluation. The intact mode configurations of the waste package containing ATR SNF include configurations that represent the waste package as being breached, allowing inflow of water. The internal components of the waste package are considered intact. Unless noted otherwise, all unoccupied spaces inside the DOE Standardized SNF Canister and waste package are modeled as filled with water. Variations of the intact configurations are examined to identify the configuration that results in the highest calculated k_eff value within the range of possible conditions. Figure 18 presents a cross-sectional view of the baseline intact configuration modeled with MCNP. The fuel is settled in gravitationally stable positions in each compartment. The ATR fuel elements were rotated, as well as the canister. Cases were also run to analyze the effectiveness of the design solution regarding introduction of additional $\mathrm{Gd}$ as a neutron absorber distributed with a moderator displacer (Al shot). 


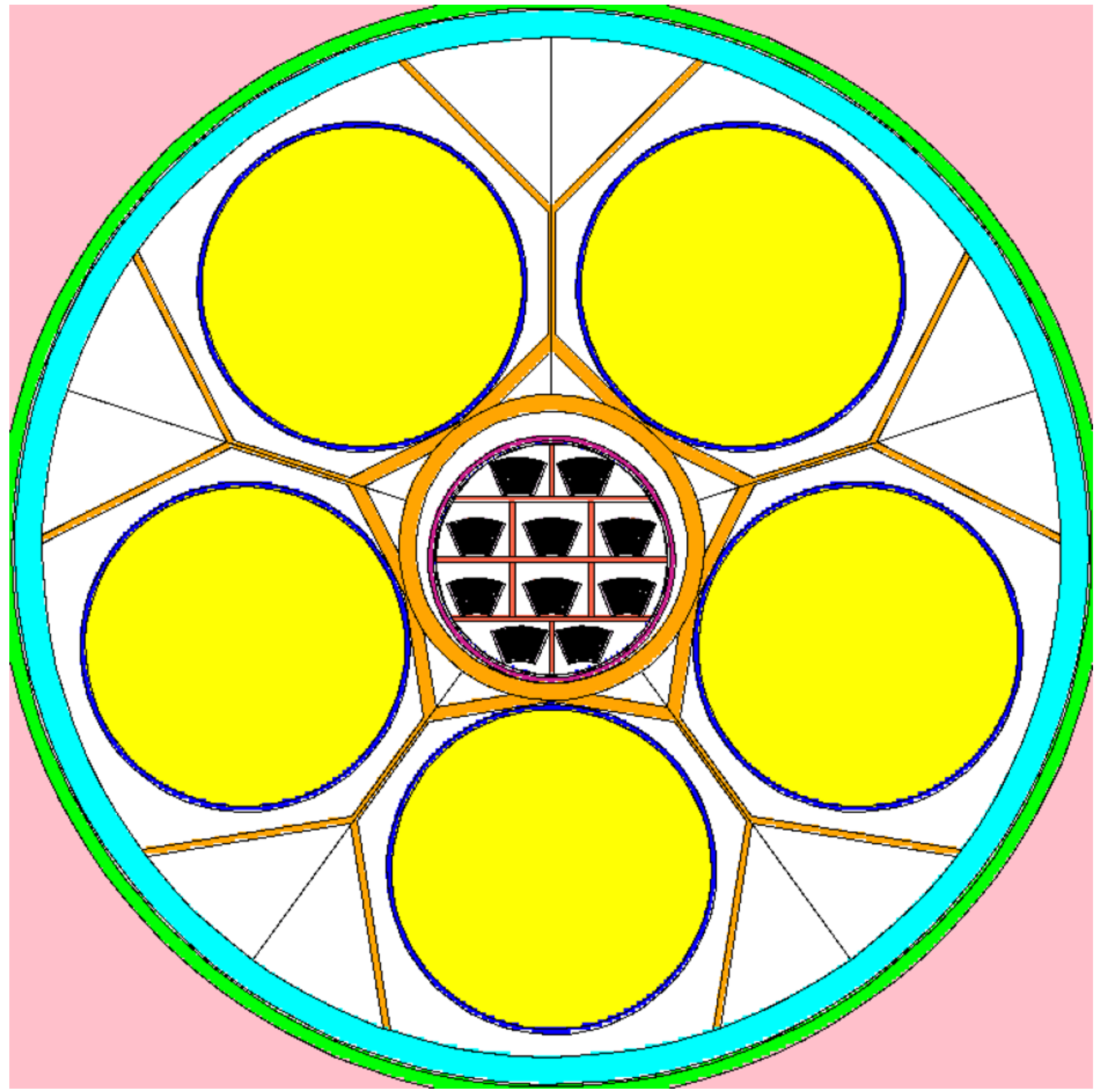

Figure 18. Intact ATR fuel in a codisposal waste package.

If the DOE Standardized SNF Canister is breached shortly after the breach and flooding of the waste package, the ATR SNF fuel will start to degrade in place, resulting in degraded fuel inside the canister. The configurations can include partially degraded to completely degraded fuel placed in the basket compartments of the canister. The $\mathrm{Al}$ was assumed to degraded to gibbsite $\left[\mathrm{Al}(\mathrm{OH})_{3}\right]$ and uranium to schoepite $\left[\left(\mathrm{UO}_{2}\right)_{8} \mathrm{O}_{2}(\mathrm{OH})_{12 .} 12\left(\mathrm{H}_{2} \mathrm{O}\right)\right]$. The degraded materials expand and quickly fill the available space inside the canister. The basket material containing borated stainless steel does not degrade and stays in place. The degradation products are considered homogeneously mixed and formed with various values for internal porosity. The expansion of the degradation products is limited by the space available in each compartment. Figure 19 displays the degraded configuration. 


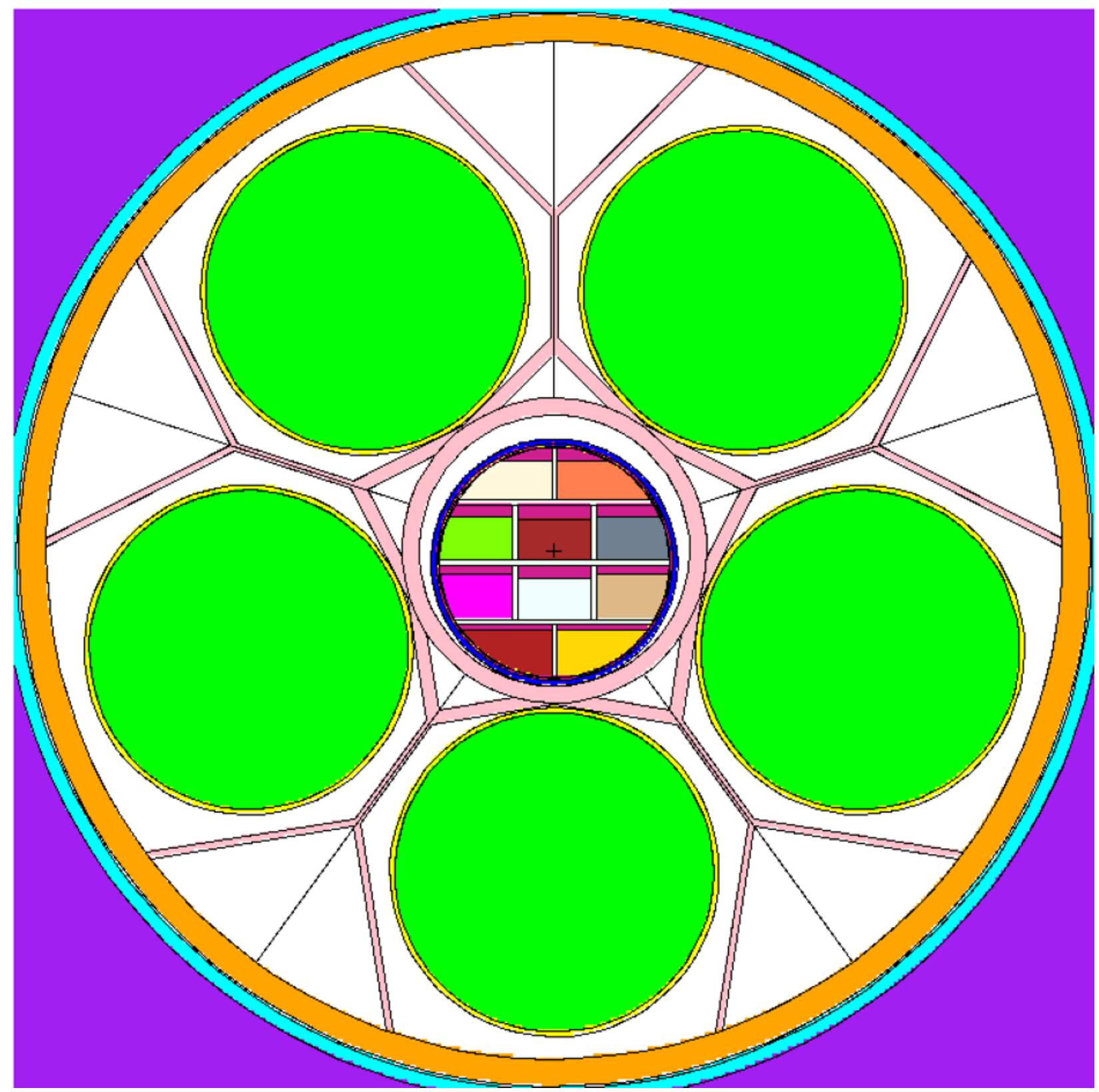

Figure 19. Degraded ATR fuel surrounded by intact DHLW canisters in a codisposal waste package.

If the DOE Standardized SNF Canister breaches long after the breaching of the waste package, then the resulting scenario will be degraded components outside the canister. This intact canister is surrounded by pre-breach clay. At some point in time, the canister will breach, allowing internal fuel to degrade as presented in Figure 20. This scenario includes the aluminum shot interspersed with gadolinium in each case evaluated. 


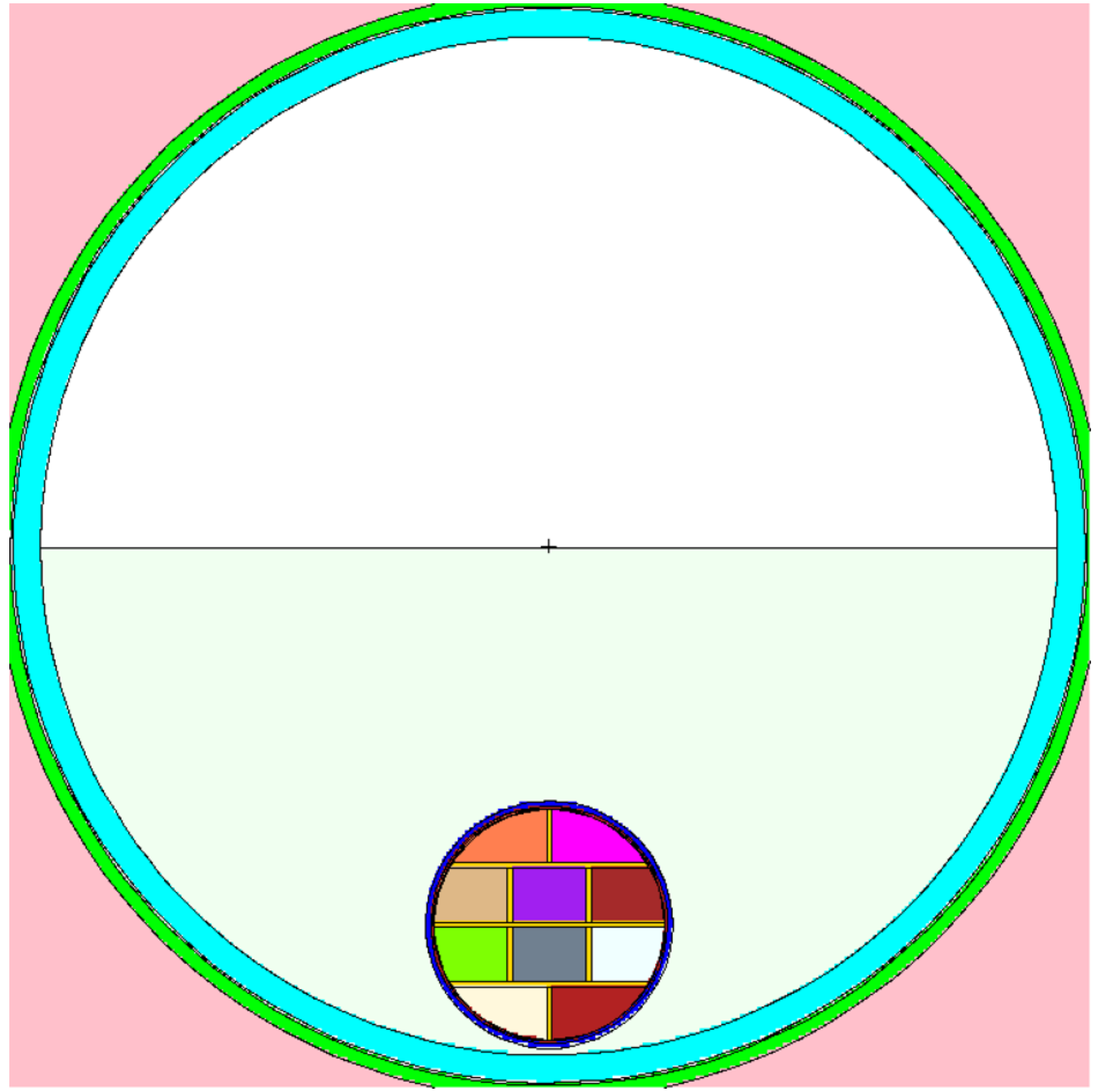

Figure 20. Degraded ATR fuel surrounded by pre-breach clay.

The final stage of degradation, completely degraded, was not evaluated in this analysis. It involves configurations in which the content of the DOE Standardized SNF Canister is mixed with the degradation products obtained from the degradation of the waste package internals. This was outside the scope of this evaluation, since borated stainless steel cannot be expected at this time to always stay within the waste package. Results substituting 304B4 (1.00\% and 1.17\%) for ANA are found in Section 5.3. 


\subsection{Additional Analyses}

Additional analyses were performed for the OCRWM analyses. The first substitutes a 0.4 inch borated stainless steel (304B4 1.00\%) basket for the 0.375 inch ANA basket. The second substitutes borated stainless steel (304B5 1.25\% and 304B6 1.50\%) for ANA. Results for these additional analyses are found in sections 5.4 and 5.5, respectively. Intact scenarios are not modeled because the k_eff is well under the upper criticality limit for this scenario.

\section{RESULTS}

The results of this evaluation are contained in Sections 5.1-5.5. Section 5.1 contains the results from the BSC vs. OCRWM sensitivity evaluation. Section 5.2 compares ANA with borated stainless steel in the BSC evaluation. Section 5.3 compares ANA with borated stainless steel in the OCRWM evaluation. Section 5.4 compares an increase to the thickness of the borated stainless steel basket. Section 5.5 compares 304B4, 304B5, and 304B6.

\subsection{BSC vs. OCRWM Sensitivity Evaluation}

This section performs a sensitivity evaluation to understand the most important factors for calculating $\mathrm{k}$ _eff. Each case changes at least one variable from the BSC analysis to match the OCRWM analysis. The last case replaces all of the variables. The original BSC base case modelling degraded ATR fuel with a $30 \%$ void fraction inside an intact DOE Standardized SNF Canister positioned in the bottom of the waste package surrounded by prebreach clay had a k_eff of $0.6738 \pm 0.0010$. The original OCRWM base case modelling degraded ATR fuel with a $30 \%$ void fraction inside an intact DOE Standardized SNF Canister positioned between five DHLW canisters in the center of the waste package had a k_eff value of $0.9521 \pm$ 0.0008. Table 21 lists the k_eff for the cases.

Table 21. Comparing differences in the BSC evaluation with degraded ATR fuel having a 30\% void fraction in an intact DOE Standardized SNF Canister surrounded by prebreach clay positioned at the bottom of the waste package and the OCRWM evaluation with degraded ATR fuel having a $30 \%$ void fraction in an intact DOE Standardized Canister surrounded by prebreach clay positioned at the center of five DHLW canisters in the waste package.

\begin{tabular}{|l|l|c|l|}
\hline Case & Case Name & k_eff $\pm \boldsymbol{\sigma}$ & Description \\
\hline 0a & ATR_degraded_wvf3b.o & $0.6738 \pm 0.0010$ & $\begin{array}{l}\text { BSC base case describing degraded ATR fuel inside of a } \\
\text { DOE Standardized SNF Canister positioned in the } \\
\text { bottom of the waste package surrounded by prebreach } \\
\text { clay }\end{array}$ \\
\hline 1 & ATR_pdeg_tot_30_wet & $0.9521 \pm 0.0008$ & $\begin{array}{l}\text { OCRWM base case describing ATR fuel inside of a } \\
\text { DOE Standardized SNF Canister positioned in the } \\
\text { center of the waste package surrounded by DHLW } \\
\text { canisters }\end{array}$ \\
\hline 2 & ATR_degraded_wvf3b_Internal.o & $0.89762 \pm 0.00105$ & $\begin{array}{l}\text { Change material composition of degraded fuel in BSC } \\
\text { base case from a uranium/water/diaspore mixture to the } \\
\text { gibbsite/schoepite/water mixture used in the OCRWM } \\
\text { base case }\end{array}$ \\
\hline 3 & $\begin{array}{l}\text { ATR_degraded_wvf3b_HLW_Int } \\
\text { act.o }\end{array}$ & $\begin{array}{l}\text { Changed the position of the DOE Standardized SNF } \\
\text { canister in the BSC base case to be situated in the } \\
\text { middle of the five intact DHLW canisters as it is in the } \\
\text { OCRWM base case }\end{array}$ \\
\hline 4 & ATR_degraded_wvf3b_Internal_ & $0.71472 \pm 0.00113$ & \begin{tabular}{l} 
Combination of case 1 and 2 \\
\hline
\end{tabular} \\
\hline
\end{tabular}




\begin{tabular}{|c|c|c|c|}
\hline Case & Case Name & k_eff $\pm \sigma$ & Description \\
\hline 5 & $\begin{array}{l}\text { ATR_degraded_wvf3b_Internal_ } \\
\text { Clay.o }\end{array}$ & $0.89486 \pm 0.00108$ & Combination of case 1 and 4 \\
\hline 6 & ATR_degraded_wvf3b_Tuff.o & $0.67711 \pm 0.00099$ & $\begin{array}{l}\text { Change surrounding tuff in BSC base case to match } \\
\text { OCRWM base case }\end{array}$ \\
\hline 7 & $\begin{array}{l}\text { ATR_degraded_wvf3b_Internal_ } \\
\text { Tuff.o }\end{array}$ & $0.89905 \pm 0.00089$ & Combination of case 1 and 6 \\
\hline 8 & $\begin{array}{l}\text { ATR_degraded_wvf3b_Clay_Tuf } \\
\text { f.o }\end{array}$ & $0.67600 \pm 0.00108$ & Combination of case 4 and 6 \\
\hline 9 & $\begin{array}{l}\text { ATR_degraded_wvf3b_Internal_ } \\
\text { Clay_Tuff.o }\end{array}$ & $0.89897 \pm 0.00101$ & Combination of cases 7 and 8 \\
\hline 10 & $\begin{array}{l}\text { ATR_degraded_wvf3b_Internal_ } \\
\text { HLW_Intact_Tuff.o }\end{array}$ & $0.94590 \pm 0.00105$ & Combination of cases 3 and 7 \\
\hline 11 & ATR_degraded_wvf3b_ANA.o & $0.67676 \pm 0.00099$ & $\begin{array}{l}\text { Change ANA in BSC base case to use values provided } \\
\text { in OCRWM base case }\end{array}$ \\
\hline 12 & ATR_degraded_wvf3b_CS.o & $0.67267 \pm 0.00107$ & $\begin{array}{l}\text { Change carbon steel in BSC base case to use values } \\
\text { provided in OCRWM base case }\end{array}$ \\
\hline 13 & ATR_degraded_wvf3b_SS.o & $0.67040 \pm 0.00111$ & $\begin{array}{l}\text { Change stainless steel in BSC base case to use values } \\
\text { provided in OCRWM base case }\end{array}$ \\
\hline 14 & $\begin{array}{l}\text { ATR_degraded_wvf3b_Canister_ } \\
\text { Mat.o }\end{array}$ & $0.67697 \pm 0.00102$ & Combination of cases 11,12 , and 13 \\
\hline 15 & $\begin{array}{l}\text { ATR_degraded_wvf3b_Internal_ } \\
\text { Canister_Mat.o }\end{array}$ & $0.90355 \pm 0.00092$ & Combination of case 1 and 14 \\
\hline 16 & $\begin{array}{l}\text { ATR_degraded_wvf3b_Internal_ } \\
\text { HLW_Intact_Canister_Mat.o }\end{array}$ & $0.95339 \pm 0.00103$ & Combination of cases 3 and 15 \\
\hline 17 & $\begin{array}{l}\text { ATR_degraded_wvf3b_Canister_ } \\
\text { Dim.o }\end{array}$ & $0.92237 \pm 0.00101$ & $\begin{array}{l}\text { Change canister dimensions in BSC base case to match } \\
\text { OCRWM base case and case } 1\end{array}$ \\
\hline 18 & $\begin{array}{l}\text { ATR_degraded_wvf3b_Internal_ } \\
\text { HLW_Intact_Canister_Dim.o }\end{array}$ & $0.92601 \pm 0.00108$ & Combination of cases 3 and 17 \\
\hline 19 & $\begin{array}{l}\text { ATR_degraded_wvf3b_All_Canis } \\
\text { ter.o }\end{array}$ & $0.95027 \pm 0.00112$ & Combination of 14 and 18 \\
\hline 20 & $\begin{array}{l}\text { ATR_degraded_wvf3b_HLW_Int } \\
\text { act_Source.o }\end{array}$ & $0.71455 \pm 0.00100$ & $\begin{array}{l}\text { Change the source in the BSC base case to match the } \\
\text { source used in the OCRWM base case and case } 2\end{array}$ \\
\hline 21 & ATR_degraded_wvf3b_All.o & $0.95209 \pm 0.00108$ & Combination of cases 19 and 20 \\
\hline
\end{tabular}

Because the BSC and OCRWM evaluations came to two different conclusions, it is important to know which factors changed the k_eff of the system the most. Changing the DOE Standardized SNF Canister's internals (degraded ATR composition and basket size) has the biggest impact on k_eff. It is important to note neither of these cases had the maximum void fraction. The maximum void fraction represents the percentage of water that can be homogenously mixed with the material within the confined basket boundary. The maximum void fraction for the BSC evaluation was 0.74 . The maximum void fraction for the OCRWM evaluation was 0.48. The BSC evaluation assumed that the SNF degraded into a homogenous mixture of uranium, water, and diaspore. There is no volume expansion performed for this degradation. The OCRWM evaluation assumed the Al degraded to gibbsite accompanied by a volumetric expansion of approximately 3.2. It also assumed the uranium degraded to schoepite accompanied by a volumetric expansion of approximately 5.35. This allowed less water to be homogeneously mixed with degraded materials than in the BSC evaluation. In the compared scenarios above, the void fraction was 0.30. Figure 21 shows the two cases modeled side by side showing the difference between physical expansion of degraded material. Both cases fill all void space within the DOE Standardized SNF Canister with water. 


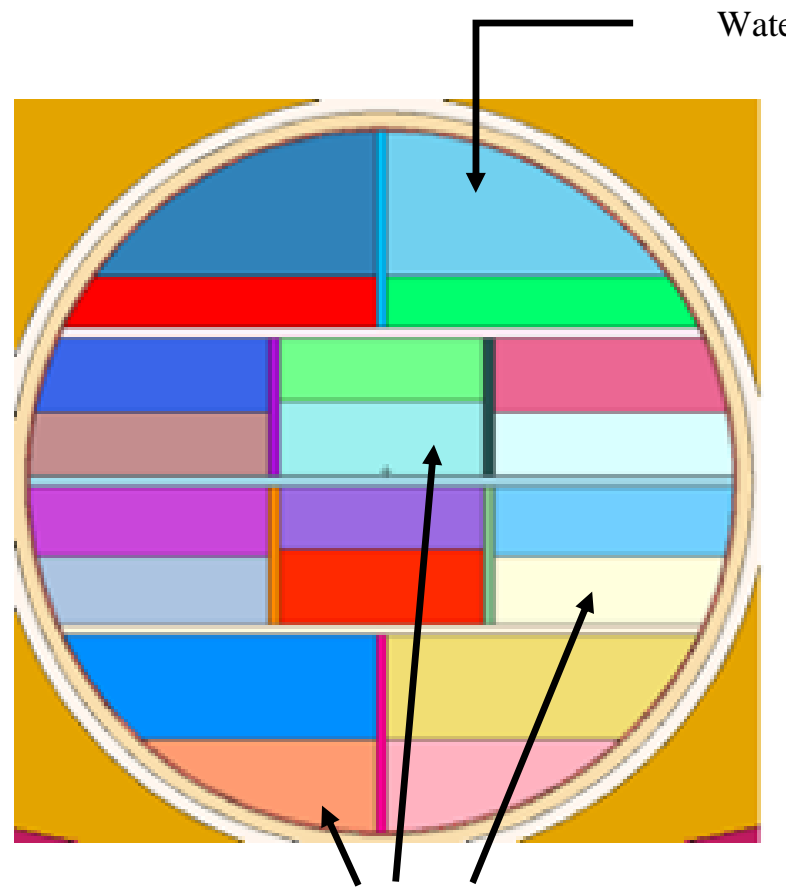

Uranium/Diaspore/Water

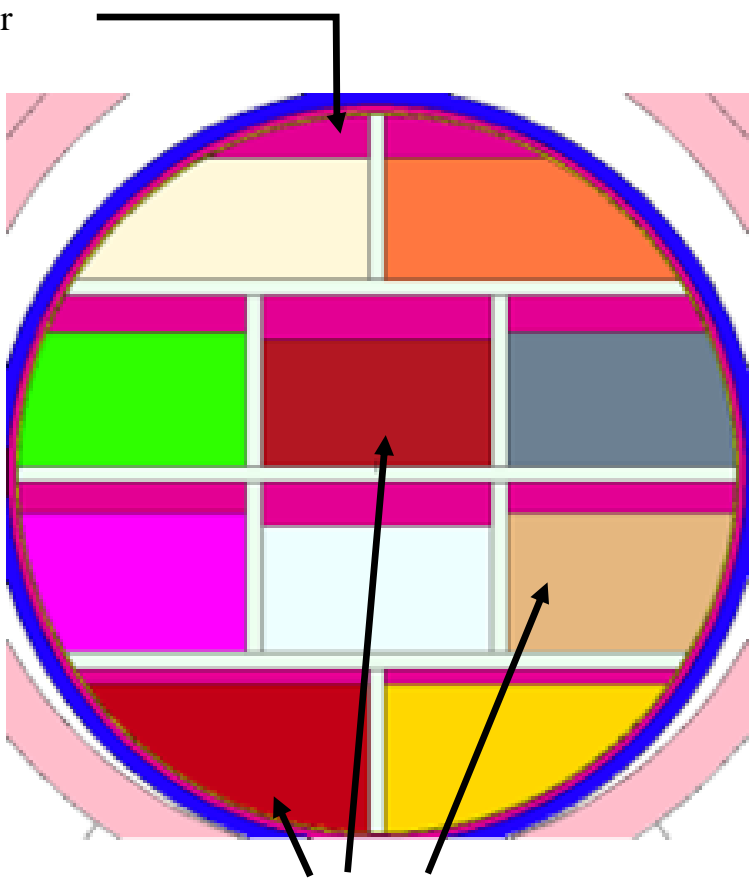

Schoepite/Gibbsite/Water

Figure 21. The image on the left represents degraded fuel in a DOE Standardized SNF Canister with a void fraction of 0.3 completely filled with water from the BSC evaluation. The image on the right represents degraded fuel in a DOE Standardized SNF Canister with a void fraction of 0.3 completely filled with water from the OCRWM evaluation.

The degraded material in the BSC evaluation on the left does not fill the basket compartments as much as the degraded material in the OCRWM evaluation on the right. K_eff was increased most significantly by the substitution of the degraded ATR material, with the basket size having a much smaller effect. Changing the other material compositions had little to no effect.

\subsection{Comparing ANA and Borated Stainless Steel in BSC's Evaluation}

This section compares ANA to borated stainless steel using the BSC evaluation. It also implements and compares a geometry correction applied to the model described in Section 4.2. This correction is found in the column "BSS New Configuration." This scenario has a basket thickness of 0.25 inches - the thinnest out of all the scenarios. Table 22 compares ANA and borated stainless steel in the BSC evaluation.

Table 22. Replacing ANA with 304B4 (1.00\%B) with a basket thickness of 0.25 inches. The geometric error is fixed in the BSS new configuration. 


\begin{tabular}{|c|c|c|c|c|c|}
\hline State & Name & Description & $\begin{array}{c}\text { ANA Old } \\
\text { Configuration } \\
\text { k_eff } \pm \sigma\end{array}$ & $\begin{array}{c}\text { BSS Old } \\
\text { Configuration } \\
\text { k_eff } \pm \sigma\end{array}$ & $\begin{array}{c}\text { BSS New } \\
\text { Configuration } \\
\text { k_eff } \pm \sigma\end{array}$ \\
\hline Intact & atr_drywpwetsnf_bss & $\begin{array}{l}\text { Same as atr_wpsmba } \\
\text { except volume outside of } \\
\text { SNF canister is dry }\end{array}$ & $0.6689 \pm 0.0012$ & $0.6493 \pm 0.0011$ & $0.6465 \pm 0.0011$ \\
\hline Intact & atr_wpdry_bss & ATR waste package dry & $0.0702 \pm 0.0002$ & $0.0671 \pm 0.0002$ & $0.0668 \pm 0.0002$ \\
\hline Intact & atr_wpsmba_bss & $\begin{array}{l}\text { ATR waste package fully } \\
\text { flooded and basket } \\
\text { dimensions maximizing } \\
\text { interactions between } \\
\text { elements }\end{array}$ & $0.6562 \pm 0.0011$ & $0.6344 \pm 0.0011$ & $0.6361 \pm 0.0010$ \\
\hline Intact & atr_wpwatbas & $\begin{array}{l}\text { Same as atr_wpsmba but } \\
\text { basket material replaced } \\
\text { by water }\end{array}$ & $1.0061 \pm 0.0010$ & $1.0082 \pm 0.0010$ & $1.0058 \pm 0.0010$ \\
\hline Intact & atr_wpwet_bss & $\begin{array}{l}\text { ATR waste package fully } \\
\text { flooded }\end{array}$ & $0.6390 \pm 0.0010$ & $0.6254 \pm 0.0011$ & $0.6226 \pm 0.0010$ \\
\hline Intact & atr_wpwett1_bss & $\begin{array}{l}\text { ATR waste package fully } \\
\text { flooded, fuel in most } \\
\text { reactive geometry }\end{array}$ & $0.6432 \pm 0.0010$ & $0.6254 \pm 0.0010$ & $0.6263 \pm 0.0011$ \\
\hline Intact & vf_04_bss & $\begin{array}{l}\text { Same as atr_wpsmba with } \\
4 \% \text { void fraction }\end{array}$ & $0.6568 \pm 0.0010$ & $0.6395 \pm 0.0011$ & $0.6386 \pm 0.0011$ \\
\hline Intact & vf_08_bss & $\begin{array}{l}\text { Same as atr_wpsmba with } \\
8 \% \text { void fraction }\end{array}$ & $0.6618 \pm 0.0011$ & $0.6401 \pm 0.0011$ & $0.6410 \pm 0.0011$ \\
\hline Intact & v_12_bss & $\begin{array}{l}\text { Same as atr_wpsmba with } \\
12 \% \text { void fraction }\end{array}$ & $0.6639 \pm 0.0010$ & $0.6431 \pm 0.0011$ & $0.6429 \pm 0.0012$ \\
\hline $\begin{array}{l}\text { Degraded } \\
\text { Fuel }\end{array}$ & degraded_bss & $\begin{array}{l}\text { Degraded fuel with water } \\
\text { volume fraction of } 0\end{array}$ & $0.5464 \pm 0.0010$ & $0.5418 \pm 0.00097$ & $0.5423 \pm 0.0009$ \\
\hline $\begin{array}{l}\text { Degraded } \\
\text { Fuel }\end{array}$ & degraded_wvf1_bss & $\begin{array}{l}\text { Degraded fuel with water } \\
\text { volume fraction of } .1\end{array}$ & $0.5825 \pm 0.0011$ & $0.5770 \pm 0.00094$ & $0.5745 \pm 0.0010$ \\
\hline $\begin{array}{l}\text { Degraded } \\
\text { Fuel }\end{array}$ & degraded_wvf2_bss & $\begin{array}{l}\text { Degraded fuel with water } \\
\text { volume fraction of } .2\end{array}$ & $0.6256 \pm 0.0010$ & $0.6185 \pm 0.00095$ & $0.6202 \pm 0.0010$ \\
\hline $\begin{array}{l}\text { Degraded } \\
\text { Fuel }\end{array}$ & degraded_wvf3_bss & $\begin{array}{l}\text { Degraded fuel with water } \\
\text { volume fraction of } .3\end{array}$ & $0.6782 \pm 0.0011$ & $0.6685 \pm 0.00108$ & $0.6683 \pm 0.0010$ \\
\hline $\begin{array}{l}\text { Degraded } \\
\text { Fuel }\end{array}$ & degraded_wvf4_bss & $\begin{array}{l}\text { Degraded fuel with water } \\
\text { volume fraction of } .4\end{array}$ & $0.7420 \pm 0.0011$ & $0.7298 \pm 0.00101$ & $0.7286 \pm 0.0011$ \\
\hline $\begin{array}{l}\text { Degraded } \\
\text { Fuel }\end{array}$ & degraded_wvf5_bss & $\begin{array}{l}\text { Degraded fuel with water } \\
\text { volume fraction of } .5\end{array}$ & $0.8135 \pm 0.0011$ & $0.7995 \pm 0.00099$ & $0.7980 \pm 0.0011$ \\
\hline $\begin{array}{l}\text { Degraded } \\
\text { Fuel }\end{array}$ & degraded_wvf6_bss & $\begin{array}{l}\text { Degraded fuel with water } \\
\text { volume fraction of .6 }\end{array}$ & $0.8898 \pm 0.0011$ & $0.8715 \pm 0.00098$ & $0.8732 \pm 0.0011$ \\
\hline $\begin{array}{l}\text { Degraded } \\
\text { Fuel }\end{array}$ & degraded_wvf62_bss & $\begin{array}{l}\text { Degraded fuel with water } \\
\text { volume fraction of } .62\end{array}$ & $0.9012 \pm 0.0011$ & $0.8814 \pm 0.00102$ & $0.8819 \pm 0.0011$ \\
\hline $\begin{array}{l}\text { Degraded } \\
\text { Fuel }\end{array}$ & degraded_wvf66_bss & $\begin{array}{l}\text { Degraded fuel with water } \\
\text { volume fraction of . } 66 \text { two } \\
\text { innermost ports full with a } \\
\text { water fraction of } .62\end{array}$ & $0.9108 \pm 0.0010$ & $0.8946 \pm 0.00097$ & $0.8938 \pm 0.0010$ \\
\hline $\begin{array}{l}\text { Degraded } \\
\text { Fuel }\end{array}$ & degraded_wvf75_bss & $\begin{array}{l}\text { Degraded fuel filling each } \\
\text { port four outer most ports } \\
\text { with water volume } \\
\text { fraction of } .75 \text {, four outer } \\
\text { ports in center with water } \\
\text { volume fraction } .66 \text { and } \\
\text { two innermost ports full } \\
\text { with a water fraction } \\
\text { of } .62\end{array}$ & $0.9330 \pm 0.0010$ & $0.9158 \pm 0.00099$ & $0.9148 \pm 0.0011$ \\
\hline
\end{tabular}

K_eff decreased in every case where borated stainless steel was used, as opposed to ANA, for the basket material. The k_eff for an intact scenario never exceeds 0.70 . The maximum k_eff of $0.9330 \pm$ 
0.0010 was calculated in a case that completely filled all ANA basket compartments with a homogeneous mixture of uranium, diaspore, and water. BSC concluded that the basket thickness needed to be increased in order to attain a calculated k_eff less than the upper critical limit of 0.93. Instead of increasing the thickness, this evaluation substituted in a borated stainless steel basket with $1.00 \%$ boron. This substitution dropped the k_eff down to less than 0.92, which was deemed acceptable for this evaluation. If all the assumptions were correct for the BSC evaluation, the basket thickness of the DOE Standardized SNF Canister to ensure sub-criticality would be 0.25 inches.

\subsection{Comparing ANA and Borated Stainless Steel in OCRWM's evaluation}

This section uses the OCRWM evaluation to compare a basket made from ANA and borated stainless steel 304B4 with compositions of $1.00 \%$ and $1.17 \%$ boron. The OCRWM evaluation uses a basket thickness of 0.375 in for every scenario. Tables 23 through 25 list the intact, degraded, and degraded with gadolinium shot results for the configurations described in Section 4.3.

Table 23. Calculated results for intact scenarios replacing ANA with 304B4.

\begin{tabular}{|c|c|c|c|c|}
\hline Case Name & Description & $\begin{array}{c}\text { ANA } \\
\mathbf{k} \_ \text {eff } \pm \sigma\end{array}$ & $\begin{array}{c}304 \text { B4 1.17\% B } \\
\text { k_eff } \pm \sigma\end{array}$ & $\begin{array}{c}\text { 304B4 } 1.00 \% \text { B } \\
\text { k_eff } \pm \sigma\end{array}$ \\
\hline atr_int_1a-s_bss.o & $\begin{array}{l}\text { Initial base case. Fuel elements } \\
\text { placed in gravitationally stable } \\
\text { positions in each compartment. } \\
\text { DOE SNF canister is settled in the } \\
\text { support tube. Fuel meat has } 11 \\
\text { vol\% inner porosity (void). All } \\
\text { other available spaces in the waste } \\
\text { package are filled with full } \\
\text { density water. Waste package is } \\
\text { surrounded by dry tuff }\end{array}$ & $0.6243 \pm 0.0008$ & $0.58858 \pm 0.00079$ & $0.59681 \pm 0.00081$ \\
\hline atr_int_2a-s_bss.o & $\begin{array}{l}\text { Similar to base case, but inner } \\
\text { porosity in fuel meat is only } 3 \\
\text { vol\% (void) }\end{array}$ & $0.6243 \pm 0.0008$ & $0.59093 \pm 0.00079$ & $0.59576 \pm 0.00083$ \\
\hline atr_int_3a-s_bss.o & $\begin{array}{l}\text { Similar to base case, but DOE } \\
\text { SNF canister is centered in the } \\
\text { support tube of the waste package }\end{array}$ & $0.6176 \pm 0.0008$ & $0.58431 \pm 0.00079$ & $0.59046 \pm 0.00081$ \\
\hline atr_int_1b-s_bss.o & $\begin{array}{l}\text { Similar to base case, but fuel } \\
\text { elements in middle row are } \\
\text { rotated with } 180 \text { degrees }\end{array}$ & $0.625 \pm 0.0008$ & $0.58991 \pm 0.00082$ & $0.59604 \pm 0.00078$ \\
\hline atr_int_1c-s_bss.o & $\begin{array}{l}\text { Similar to base case, but upper } \\
\text { half of the basket has all fuel } \\
\text { elements rotated with } 180 \text { degrees }\end{array}$ & $0.625 \pm 0.0008$ & $0.58969 \pm 0.00084$ & $0.59671 \pm 0.00080$ \\
\hline atr_int_1a-s-rot_bss.o & $\begin{array}{l}\text { Similar to base case, but basket } \\
\text { rotated with } 90 \text { degrees }\end{array}$ & $0.6215 \pm 0.0008$ & $0.58616 \pm 0.00079$ & $0.59380 \pm 0.00084$ \\
\hline atr_int_1a-s-rot-s_bss.o & $\begin{array}{l}\text { Similar to above case, but fuel } \\
\text { elements are settled in each } \\
\text { compartment in gravitationally } \\
\text { stable positions }\end{array}$ & $0.624 \pm 0.0008$ & $0.58616 \pm 0.00080$ & $0.59395 \pm 0.00081$ \\
\hline atr_int_1a-s-dry_bss.o & $\begin{array}{l}\text { Similar to base case, but no water } \\
\text { in the waste package }\end{array}$ & $0.0696 \pm 0.0001$ & $0.06446 \pm 0.00011$ & $0.06533 \pm 0.00011$ \\
\hline atr_int_1a-s-pf_bss.o & $\begin{array}{l}\text { Similar to base case, but only } \\
\text { DOE SNF canister is flooded }\end{array}$ & $0.6412 \pm 0.0008$ & $0.60700 \pm 0.00077$ & $0.61370 \pm 0.00083$ \\
\hline atr_int_1a-s-pf-chlw_bss.o & $\begin{array}{l}\text { Similar to above case, but DHLW } \\
\text { canister are repositioned in a } \\
\text { gravitationally stable geometry }\end{array}$ & $0.6368 \pm 0.0008$ & $0.60423 \pm 0.00080$ & $0.61154 \pm 0.00079$ \\
\hline
\end{tabular}




\begin{tabular}{|c|c|c|c|c|}
\hline Case Name & Description & $\begin{array}{c}\text { ANA } \\
\mathbf{k} \_ \text {eff } \pm \sigma\end{array}$ & $\begin{array}{c}304 \text { B4 1.17\% B } \\
\text { k_eff } \pm \sigma\end{array}$ & $\begin{array}{c}\text { 304B4 1.00 \% B } \\
\text { k_eff } \pm \sigma\end{array}$ \\
\hline atr_int_1a-s-refl_bss.o & $\begin{array}{l}\text { Similar to base case, but the waste } \\
\text { package has reflective boundary } \\
\text { conditions }\end{array}$ & $0.6243 \pm 0.0008$ & $0.58858 \pm 0.00079$ & $0.59681 \pm 0.00081$ \\
\hline atr_int_1a-s-w070_bss.o & $\begin{array}{l}\text { Similar to base case, but water } \\
\text { density is } 0.75 \mathrm{~g} / \mathrm{cm} 3\end{array}$ & $0.5493 \pm 0.0008$ & $0.50251 \pm 0.00077$ & $0.51093 \pm 0.00075$ \\
\hline atr_int_1a-s-w080_bss.o & $\begin{array}{l}\text { Similar to base case, but water } \\
\text { density is } 0.80 \mathrm{~g} / \mathrm{cm} 3\end{array}$ & $0.5788 \pm 0.0008$ & $0.53443 \pm 0.00081$ & $0.54450 \pm 0.00082$ \\
\hline atr_int_1a-s-w090_bss.o & $\begin{array}{l}\text { Similar to base case, but water } \\
\text { density is } 0.90 \mathrm{~g} / \mathrm{cm} 3\end{array}$ & $0.6028 \pm 0.0008$ & $0.56502 \pm 0.00080$ & $0.57210 \pm 0.00085$ \\
\hline atr_int_1a-s-w095_bss.o & $\begin{array}{l}\text { Similar to base case, but water } \\
\text { density is } 0.95 \mathrm{~g} / \mathrm{cm} 3\end{array}$ & $0.6139 \pm 0.0008$ & $0.57515 \pm 0.00082$ & $0.58466 \pm 0.00081$ \\
\hline atr_int_1a-s-04vfw_bss.o & $\begin{array}{l}\text { Similar to base case, but water } \\
\text { fills partially the porosity inside } \\
\text { the fuel meat ( } 36 \% \text { of the porosity } \\
\text { is filled with full density water) }\end{array}$ & $0.6261 \pm 0.0008$ & $0.59240 \pm 0.00085$ & $0.59848 \pm 0.00082$ \\
\hline atr_int_1a-s-011vfw_bss.o & $\begin{array}{l}\text { Similar to base, but all inner } \\
\text { porosity is filled with full density } \\
\text { water }\end{array}$ & $0.6306 \pm 0.0008$ & $0.59657 \pm 0.00082$ & $0.60368 \pm 0.00085$ \\
\hline atr_int_1a-s-comb_bss.o & $\begin{array}{l}\text { Similar to case "atr_int_la-s" } \\
\text { with partial flooding (only DOE } \\
\text { SNF canister) and fuel porosity } \\
\text { filled with water }\end{array}$ & $0.6474 \pm 0.0008$ & $0.61310 \pm 0.00077$ & $0.62035 \pm 0.00082$ \\
\hline atr_int_1a-s-comb-r_bss.o & $\begin{array}{l}\text { Similar to above case, but the } \\
\text { waste package has reflective } \\
\text { boundary conditions at outer } \\
\text { surfaces }\end{array}$ & $0.6484 \pm 0.0008$ & $0.61494 \pm 0.00083$ & $0.62048 \pm 0.00086$ \\
\hline atr_int_1a-s-ngd_bss.o & $\begin{array}{l}\text { Similar to base case but no } \\
\text { neutron absorber in basket }\end{array}$ & $0.715 \pm 0.0008$ & $0.59163 \pm 0.00083$ & $0.59840 \pm 0.00086$ \\
\hline $\begin{array}{l}\text { atr_int_1a-s-comb- } \\
\text { AlGd01shot_bss.o }\end{array}$ & $\begin{array}{l}\text { Similar to case "atr_int_la-s- } \\
\text { comb," but additional Gd is } \\
\text { introduced with Al fill material } \\
\text { that occupies all spaces around } \\
\text { fuel elements in each } \\
\text { compartment. Gd content is } 0.1 \\
\text { wt\% in Al fill material (mixture of } \\
\text { Al shot and gadolinium } \\
\text { phosphate). }\end{array}$ & $0.4394 \pm 0.0007$ & $0.41157 \pm 0.00073$ & $0.41699 \pm 0.00070$ \\
\hline
\end{tabular}

The k_eff of the intact scenario never exceeds 0.70. A basket fabricated from ANA had the highest k_eff, followed 304B4 with $1.00 \%$ boron, concluding with 304B 4 with a $1.17 \%$ boron concentration in every case.

Table 24. Results for configurations with complete degradation of ATR SNF inside DOE Standardized SNF Canister with DHLW canister intact.

\begin{tabular}{|c|l|c|c|c|}
\hline Case Name & \multicolumn{1}{|c|}{ Description } & $\begin{array}{c}\text { ANA } \\
\mathbf{k} \_ \text {eff } \pm \boldsymbol{\sigma}\end{array}$ & $\begin{array}{c}\text { 304 B4 1.17\% B } \\
\mathbf{k} \_ \text {eff } \pm \boldsymbol{\sigma}\end{array}$ & $\begin{array}{c}\text { 304B4 1.00\% B } \\
\mathbf{k} \_ \text {eff } \pm \boldsymbol{\sigma}\end{array}$ \\
\hline atr_pdeg_tot00_bss.o & $\begin{array}{l}\text { Fuel elements completely } \\
\text { degraded to mixture of schoepite } \\
\text { and gibbsite; mixture with no } \\
\text { voids; water above fuel in each } \\
\text { compartment and in DOE SNF }\end{array}$ & $0.8242 \pm 0.0008$ & $0.78729 \pm 0.00087$ & $0.79550 \pm 0.00085$ \\
\hline
\end{tabular}




\begin{tabular}{|c|c|c|c|c|}
\hline Case Name & Description & $\underset{\mathbf{k} \_ \text {eff } \pm \sigma}{\text { ANA }}$ & $\begin{array}{c}304 \text { B4 1.17\% B } \\
\text { k_eff } \pm \sigma\end{array}$ & $\begin{array}{c}\text { 304B4 1.00 \% B } \\
\text { k_eff } \pm \sigma\end{array}$ \\
\hline & $\begin{array}{l}\text { canister; rest of the waste package } \\
\text { is dry }\end{array}$ & & & \\
\hline atr_pdeg_tot00-nw_bss.o & $\begin{array}{l}\text { Similar to above case, but no } \\
\text { water in DOE canister }\end{array}$ & $0.8422 \pm 0.0008$ & $0.76580 \pm 0.00079$ & $0.78125 \pm 0.00083$ \\
\hline atr_pdeg_tot00-f_bss.o & $\begin{array}{l}\text { Similar to atr_pdeg_tot00_bss, } \\
\text { but waste package and DOE SNF } \\
\text { canister are fully flooded }\end{array}$ & $0.8064 \pm 0.0008$ & $0.76792 \pm 0.00086$ & $0.77462 \pm 0.00084$ \\
\hline atr_pdeg_tot_30void_bss.o & $\begin{array}{l}\text { Similar to case "atr_pdeg_tot00," } \\
\text { but void fraction is } 0.3 \text { in } \\
\text { mixture; water present above fuel } \\
\text { mixture and in DOE SNF canister } \\
\text { only }\end{array}$ & $0.827 \pm 0.0008$ & $0.76665 \pm 0.00087$ & $0.77945 \pm 0.00081$ \\
\hline atr_pdeg_tot_30void-nw_bss.o & $\begin{array}{l}\text { Similar to above case, but no } \\
\text { water above mixture and in DOE } \\
\text { SNF canister }\end{array}$ & $0.8049 \pm 0.0008$ & $0.72486 \pm 0.00081$ & $0.73688 \pm 0.00083$ \\
\hline atr_pdeg_tot_30void-f_bss.o & $\begin{array}{l}\text { Similar to above case DOE } \\
\text { canister and waste package are } \\
\text { fully flooded }\end{array}$ & $0.7982 \pm 0.0008$ & $0.74112 \pm 0.00077$ & $0.75154 \pm 0.00087$ \\
\hline atr_pdeg_tot_30wet_bss.o & $\begin{array}{l}\text { Similar with case } \\
\text { "atr_deg_tot_30void" but water } \\
\text { fills void in mixtures }\end{array}$ & $0.9521 \pm 0.0008$ & $0.90483 \pm 0.00086$ & $0.91488 \pm 0.00080$ \\
\hline atr_pdeg_tot_30wet-nw_bss.o & $\begin{array}{l}\text { Similar to above case, but the } \\
\text { water is removed from all spaces } \\
\text { in DOE SNF canister except void } \\
\text { in mixture }\end{array}$ & $0.9521 \pm 0.0008$ & $0.89391 \pm 0.00083$ & $0.90374 \pm 0.00084$ \\
\hline atr_pdeg_tot_all_wet-f_bss.o & $\begin{array}{l}\text { Similar to above case, but waste } \\
\text { package is completely flooded }\end{array}$ & $0.9747 \pm 0.0008$ & $0.88490 \pm 0.00084$ & $0.89315 \pm 0.00082$ \\
\hline atr_pdeg_tot_3040void_bss.o & $\begin{array}{l}\text { Similar to case } \\
\text { "atr_pdeg_tot_30void" but } \\
\text { mixture in six central } \\
\text { compartments forms with } 40 \\
\text { vol\% void fraction; water in DOE } \\
\text { SNF canister only }\end{array}$ & $0.8207 \pm 0.0008$ & $0.74867 \pm 0.00079$ & $0.76381 \pm 0.00076$ \\
\hline atr_pdeg_tot_3040wet_bss.o & $\begin{array}{l}\text { Similar to above case, but water } \\
\text { fills the void in the mixture }\end{array}$ & $0.9961 \pm 0.0008$ & $0.93768 \pm 0.00083$ & $0.94842 \pm 0.00081$ \\
\hline atr_pdeg_tot_fill_wet_bss.o & $\begin{array}{l}\text { Degraded mixtures are filling all } \\
\text { available space in each } \\
\text { compartment; void and spaces in } \\
\text { DOE SNF canister are filled with } \\
\text { water; the rest of the waste } \\
\text { package is dry }\end{array}$ & $0.9961 \pm 0.0008$ & $0.94542 \pm 0.00078$ & $0.95707 \pm 0.00080$ \\
\hline atr_pdeg_tot_fill_wet-f_bss.o & $\begin{array}{l}\text { Similar to above case, but waste } \\
\text { package is completely flooded }\end{array}$ & $0.9758 \pm 0.0008$ & $0.92236 \pm 0.00082$ & $0.93369 \pm 0.00080$ \\
\hline atr_pdeg_tot_all_wet_bss.o & $\begin{array}{l}\text { Similar case } \\
\text { "atr_pdeg_tot_fill"_wet" but } \\
\text { mixture in compartments } \\
\text { bordered by the inner sleeve is } \\
\text { allowed to fill all space inside } \\
\text { DOE SNF canister. Sleeve is } \\
\text { neglected; mixture is } \\
\text { homogenized for all these } \\
\text { compartments; waste package } \\
\text { outside DOE SNF canister is dry }\end{array}$ & $0.9977 \pm 0.0008$ & $0.94908 \pm 0.00076$ & $0.95841 \pm 0.00085$ \\
\hline atr_pdeg_tot_all_wet-f_bss.o & $\begin{array}{l}\text { Similar to above case, but waste } \\
\text { package is completely flooded }\end{array}$ & $0.9747 \pm 0.0008$ & $0.92625 \pm 0.00083$ & $0.93555 \pm 0.00081$ \\
\hline
\end{tabular}


The k_eff for a scenario in which the ATR fuel degrades and the DOE Standardized SNF Canister and DHLW canisters remain intact is higher than every intact scenario presented in Table 24. K_eff increases as the void fraction increases, and that void is filled with water. This is modeled physically by increasing the volume of the degraded material in the basket material with a homogeneous mixture of gibbsite, schoepite, and water until the mixture cannot expand anymore. The amount of fissile material, however, stays the same in each case. As more water is homogeneously mixed and the volume increases, the k_eff increases.

The case completely filling the ANA basket compartments with a homogeneous mixture of gibbsite, schoepite, and water had the highest k_eff of 0.9977 . This was reduced to 0.9584 using 304B 4 with a boron concentration of $1.00 \%$ and .9490 using 304B 4 with a boron concentration of $1.17 \%$ as the basket material. This case had a calculated k_eff greater than the upper criticality limit of 0.93 . Additional neutron absorber, moderator control, or a change in geometry must be performed to reduce the k_eff below the upper critical limit. The OCRWM evaluation proposed adding a gadolinium aluminum shot. Table 25 shows the results of adding this neutron absorbing, moderator displacing material.

Table 25. Results for configuration with complete degradation of ATR SNF inside DOE Standardized SNF Canister with DHLW canister intact with additional neutron absorbing shot.

\begin{tabular}{|c|c|c|c|c|}
\hline Case Name & Description & $\underset{\mathbf{k} \_ \text {eff } \pm \sigma}{\text { ANA }}$ & $\begin{array}{c}304 \text { B4 1.17\% B } \\
\text { k_eff } \pm \sigma\end{array}$ & $\begin{array}{c}\text { 304B4 1.00 \% B } \\
\text { k_eff } \pm \sigma\end{array}$ \\
\hline atr_all_gd01-al_bss.o & $\begin{array}{l}\text { Case with a geometry identical with } \\
\text { case "atr_pdeg_tot_all" from Table } \\
\text { 24. Degraded materials in } \\
\text { compartments contain a } \\
\text { homogeneous mixture of degraded } \\
\text { fuel and aluminum shot with } 0.1 \\
\text { wt\% Gd as GdPO4. The Al is } \\
\text { degraded to gibbsite that fills all } \\
\text { space available. Non-degraded } \\
\text { Aluminum is also uniformly } \\
\text { distributed in mixture. }\end{array}$ & $0.507 \pm 0.0005$ & $0.45879 \pm 0.00050$ & $0.46729 \pm 0.00051$ \\
\hline atr_all_gd01-g100_bss.o & $\begin{array}{l}\text { Similar to above case, but gibbsite is } \\
\text { filling all available space (non- } \\
\text { degraded Aluminum is neglected) }\end{array}$ & $0.5535 \pm 0.0005$ & $0.52282 \pm 0.00053$ & $0.52841 \pm 0.00051$ \\
\hline atr_all_gd01-g90_bss.o & $\begin{array}{l}\text { Similar to atr_all_gd01-g100_bss.o, } \\
\text { but gibbsite is formed with } 10 \text { vol\% } \\
\text { void filled with water }\end{array}$ & $0.5545 \pm 0.0005$ & $0.52271 \pm 0.00052$ & $0.52975 \pm 0.00047$ \\
\hline atr_all_gd01-g70_bss.o & $\begin{array}{l}\text { Similar to atr_all_gd01-g100_bss.o, } \\
\text { but gibbsite is formed with } 30 \mathrm{vol} \% \\
\text { void filled with water }\end{array}$ & $0.555 \pm 0.0005$ & $0.52501 \pm 0.00049$ & $0.53111 \pm 0.00051$ \\
\hline atr_all_gd01-g60_bss.o & $\begin{array}{l}\text { Similar to atr_all_gd01-g100_bss.o, } \\
\text { but gibbsite is formed with } 40 \mathrm{vol} \% \\
\text { void filled with water }\end{array}$ & $0.5565 \pm 0.0005$ & $0.52632 \pm 0.00051$ & $0.53023 \pm 0.00051$ \\
\hline atr_all_gd01-g50_bss.o & $\begin{array}{l}\text { Similar to above case, but gibbsite is } \\
\text { formed with } 50 \mathrm{vol} \% \text { void filled with } \\
\text { water }\end{array}$ & $0.5562 \pm 0.0005$ & $0.52676 \pm 0.00051$ & $0.53250 \pm 0.00051$ \\
\hline atr_all_gd005-g100_bss.o & $\begin{array}{l}\text { Similar to case "atr_all_gd01-g100," } \\
\text { but only } 0.05 \text { wt } \% \text { Gd in Al shot }\end{array}$ & $0.6902 \pm 0.0006$ & $0.65104 \pm 0.00064$ & $0.65889 \pm 0.00061$ \\
\hline atr_all_gd005-g90_bss.o & $\begin{array}{l}\text { Similar to case "atr_all_gd01-g90," } \\
\text { but only } 0.05 \mathrm{wt} \% \overline{\mathrm{Gd}} \text { in } \mathrm{Al} \text { shot }\end{array}$ & $0.6902 \pm 0.0006$ & $0.65186 \pm 0.00062$ & $0.65966 \pm 0.00062$ \\
\hline atr_all_gd005-g70_bss.o & $\begin{array}{l}\text { Similar to case "atr_all_gd01-g70," } \\
\text { but only } 0.05 \mathrm{wt} \% \text { Gd in Al shot }\end{array}$ & $0.6938 \pm 0.0006$ & $0.65622 \pm 0.00063$ & $0.66451 \pm 0.00065$ \\
\hline atr_all_gd005-g60_bss.o & $\begin{array}{l}\text { Similar to case "atr_all_gd01-g60," } \\
\text { but only } 0.05 \text { wt } \% \overline{\text { Gd in Al shot }}\end{array}$ & $0.6958 \pm 0.0006$ & $0.65956 \pm 0.00062$ & $0.66579 \pm 0.00058$ \\
\hline
\end{tabular}


In every case, including the cases containing neutron-absorbing shot, the borated stainless steel lowers the k_eff at both concentrations. As expected, the 1.17\% 304B4 performed better than the 1.00\% 304B4. The one case where the ANA column performs better is when stainless steel is compared to ANA without any added Gd (atr_int_1a-s-ngd_bss). The neutron-absorption properties of the basket increase as boron concentration increases., but the material becomes less resistant to corrosion. Corrosion effects are not measured in this table.

\subsection{Increasing the Basket Thickness to 0.4 inches}

This analysis uses the geometric model used in section 5.3, but increases the basket thickness to 0.4 inches from 0.375 inches. Table 26 calculates the difference in k_eff for increasing the thickness of 304B 4 with a $1.00 \%$ B from 0.375 in. to 0.40 in. This only shows the degraded cases, as it is by far the most reactive.

Table 26. Results for varying the basket thickness for degraded DOE Standardized SNF Canister and degraded fuel surrounded by intact DHLW canisters.

\begin{tabular}{|c|c|c|c|}
\hline Case Name & Description & $\begin{array}{l}\text { 304B4 } 1.00 \% \text { B } \\
0.375 \text { in. basket } \\
\quad \text { k_eff } \pm \sigma\end{array}$ & $\begin{array}{c}\text { 304B4 1.00\% B } \\
0.40 \text { in. basket } \\
\text { k_eff } \pm \sigma\end{array}$ \\
\hline atr_pdeg_tot00_bss.o & $\begin{array}{l}\text { Fuel elements completely degraded to mixture } \\
\text { of schoepite and gibbsite; mixture with no } \\
\text { voids; water above fuel in each compartment } \\
\text { and in DOE SNF canister; rest of the waste } \\
\text { package is dry }\end{array}$ & $0.79550 \pm 0.00085$ & $0.79060 \pm 0.00085$ \\
\hline atr_pdeg_tot00-nw_bss.o & $\begin{array}{l}\text { Similar to above case, but no water in DOE } \\
\text { canister }\end{array}$ & $0.78125 \pm 0.00083$ & $0.77102 \pm 0.00080$ \\
\hline atr_pdeg_tot00-f_bss.o & $\begin{array}{l}\text { Similar to atr_pdeg_tot00_bss, but waste } \\
\text { package and DOE SNF canister are fully } \\
\text { flooded }\end{array}$ & $0.77462 \pm 0.00084$ & $0.77055 \pm 0.00082$ \\
\hline atr_pdeg_tot_30void_bss.o & $\begin{array}{l}\text { Similar to case "atr_pdeg_tot } 00 \text {," but void } \\
\text { fraction is } 0.3 \text { in mixture; water present above } \\
\text { fuel mixture and in DOE SNF canister only }\end{array}$ & $0.77945 \pm 0.00081$ & $0.77293 \pm 0.00080$ \\
\hline atr_pdeg_tot_30void-nw_bss.o & $\begin{array}{l}\text { Similar to above case, but no water above } \\
\text { mixture and in DOE SNF canister }\end{array}$ & $0.73688 \pm 0.00083$ & $0.72991 \pm 0.00080$ \\
\hline atr_pdeg_tot_30void-f_bss.o & $\begin{array}{l}\text { Similar to above case DOE canister and waste } \\
\text { package are fully flooded }\end{array}$ & $0.75154 \pm 0.00087$ & $0.74750 \pm 0.00085$ \\
\hline atr_pdeg_tot_30wet_bss.o & $\begin{array}{l}\text { Similar with case "atr_deg_tot_30void" but } \\
\text { water fills void in mixtures }\end{array}$ & $0.91488 \pm 0.00080$ & $0.91119 \pm 0.00080$ \\
\hline atr_pdeg_tot_30wet-nw_bss.o & $\begin{array}{l}\text { Similar to above case, but the water is removed } \\
\text { from all spaces in DOE SNF canister except } \\
\text { void in mixture }\end{array}$ & $0.90374 \pm 0.00084$ & $0.89832 \pm 0.00080$ \\
\hline atr_pdeg_tot_all_wet-f_bss.o & $\begin{array}{l}\text { Similar to above case, but waste package is } \\
\text { completely flooded }\end{array}$ & $0.89315 \pm 0.00082$ & $0.89012 \pm 0.00085$ \\
\hline atr_pdeg_tot_3040void_bss.o & $\begin{array}{l}\text { Similar to case "atr_pdeg_tot_30void" but } \\
\text { mixture in six central compartments forms with } \\
40 \text { vol\% void fraction; water in DOE SNF } \\
\text { canister only }\end{array}$ & $0.76381 \pm 0.00076$ & $0.75679 \pm 0.00083$ \\
\hline atr_pdeg_tot_3040wet_bss.o & $\begin{array}{l}\text { Similar to above case, but water fills the void in } \\
\text { the mixture }\end{array}$ & $0.94842 \pm 0.00081$ & $0.94347 \pm 0.00084$ \\
\hline atr_pdeg_tot_fill_wet_bss.o & $\begin{array}{l}\text { Degraded mixtures are filling all available space } \\
\text { in each compartment; void and spaces in DOE } \\
\text { SNF canister are filled with water; the rest of } \\
\text { the waste package is dry }\end{array}$ & $0.95707 \pm 0.00080$ & $0.95125 \pm 0.00080$ \\
\hline atr_pdeg_tot_fill_wet-f_bss.o & $\begin{array}{l}\text { Similar to above case, but waste package is } \\
\text { completely flooded }\end{array}$ & $0.93369 \pm 0.00080$ & $0.92698 \pm 0.00079$ \\
\hline
\end{tabular}




\begin{tabular}{|c|c|c|c|}
\hline Case Name & Description & $\begin{array}{c}\text { 304B4 1.00\% B } \\
\text { 0.375 in. basket } \\
\text { k_eff } \pm \sigma\end{array}$ & $\begin{array}{c}304 B 41.00 \% \text { B } \\
0.40 \text { in. basket } \\
\text { k_eff } \pm \sigma\end{array}$ \\
\hline atr_pdeg_tot_all_wet_bss.o & $\begin{array}{l}\text { Similar case "atr_pdeg_tot_fill"_wet" but } \\
\text { mixture in compartments bordered by the inner } \\
\text { sleeve is allowed to fill all space inside DOE } \\
\text { SNF canister. Sleeve is neglected; mixture is } \\
\text { homogenized for all these compartments; waste } \\
\text { package outside DOE SNF canister is dry }\end{array}$ & $0.95841 \pm 0.00085$ & $0.95107 \pm 0.00077$ \\
\hline atr_pdeg_tot_all_wet-f_bss.o & $\begin{array}{l}\text { Similar to above case, but waste package is } \\
\text { completely flooded }\end{array}$ & $0.93555 \pm 0.00081$ & $0.92963 \pm 0.00075$ \\
\hline
\end{tabular}

Increasing the basket thickness does slightly lower the calculated k_eff value. Although the basket thickness in some areas cannot increase much beyond 0.40 inches, other areas of the basket can be increased by almost an inch. This increase in basket thickness provides extra neutron absorption properties and decreases the amount of moderator that can be mixed with the fuel. This additional thickness could be evaluated in the future to potentially ensure k_eff stays below the upper criticality limit of 0.93 even in the most reactive, degraded scenarios.

\subsection{Evaluating Different Boron Contents}

Section 5.5 evaluates different boron contents using 304B4, 304B5, and 304B6. The lower limits of boron concentration $1.00 \%, 1.25 \%$, and $1.50 \%$, respectively, were selected for increased conservatism. Table 27 compares the calculated k_eff for the different boron concentrations.

Table 27. Results for replacing the 304B4 with 304B5 and 304B6.

\begin{tabular}{|c|c|c|c|c|}
\hline Case Name & Description & $\begin{array}{c}\text { 304B4 1.00\% } \\
\text { k_eff } \pm \sigma\end{array}$ & $\begin{array}{c}\text { 304B5 } 1.25 \% \text { B } \\
\text { k_eff } \pm \sigma\end{array}$ & $\begin{array}{c}\text { 304B6 1.50\% B } \\
\text { k_eff } \pm \sigma\end{array}$ \\
\hline atr_pdeg_tot00_bss.o & $\begin{array}{l}\text { Fuel elements completely } \\
\text { degraded to mixture of } \\
\text { schoepite and gibbsite; } \\
\text { mixture with no voids; water } \\
\text { above fuel in each } \\
\text { compartment and in DOE } \\
\text { SNF canister; rest of the } \\
\text { waste package is dry }\end{array}$ & $0.79550 \pm 0.00085$ & $0.78466 \pm 0.00086$ & $0.77480 \pm 0.00087$ \\
\hline atr_pdeg_tot00-nw_bss.o & $\begin{array}{l}\text { Similar to above case, but no } \\
\text { water in DOE canister }\end{array}$ & $0.78125 \pm 0.00083$ & $0.76042 \pm 0.00083$ & $0.74412 \pm 0.00085$ \\
\hline atr_pdeg_tot00-f_bss.o & $\begin{array}{l}\text { Similar to } \\
\text { atr_pdeg_tot00_bss, but waste } \\
\text { package and DOE SNF } \\
\text { canister are fully flooded }\end{array}$ & $0.77462 \pm 0.00084$ & $0.76430 \pm 0.00085$ & $0.75565 \pm 0.00079$ \\
\hline atr_pdeg_tot_30void_bss.o & $\begin{array}{l}\text { Similar to case } \\
\text { "atr_pdeg_tot00," but void } \\
\text { fraction is } 0.3 \text { in mixture; } \\
\text { water present above fuel } \\
\text { mixture and in DOE SNF } \\
\text { canister only }\end{array}$ & $0.77945 \pm 0.00081$ & $0.76263 \pm 0.00083$ & $0.74824 \pm 0.00083$ \\
\hline atr_pdeg_tot_30void-nw_bss.o & $\begin{array}{l}\text { Similar to above case, but no } \\
\text { water above mixture and in } \\
\text { DOE SNF canister }\end{array}$ & $0.73688 \pm 0.00083$ & $0.71676 \pm 0.00082$ & $0.69979 \pm 0.00080$ \\
\hline atr_pdeg_tot_30void-f_bss.o & $\begin{array}{l}\text { Similar to above case DOE } \\
\text { canister and waste package } \\
\text { are fully flooded }\end{array}$ & $0.75154 \pm 0.00087$ & $0.73647 \pm 0.00084$ & $0.72181 \pm 0.00084$ \\
\hline
\end{tabular}




\begin{tabular}{|c|c|c|c|c|}
\hline Case Name & Description & $\begin{array}{c}\text { 304B4 1.00\% } \\
\text { k_eff } \pm \sigma\end{array}$ & $\begin{array}{c}\text { 304B5 1.25\% B } \\
\text { k_eff } \pm \sigma\end{array}$ & $\begin{array}{c}\text { 304B6 1.50\% B } \\
\text { k_eff } \pm \sigma\end{array}$ \\
\hline atr_pdeg_tot_30wet_bss.o & $\begin{array}{l}\text { Similar with case } \\
\text { "atr_deg_tot_30void" but } \\
\text { water fills void in mixtures }\end{array}$ & $0.91488 \pm 0.00080$ & $0.90335 \pm 0.00082$ & $0.89270 \pm 0.00084$ \\
\hline atr_pdeg_tot_30wet-nw_bss.o & $\begin{array}{l}\text { Similar to above case, but the } \\
\text { water is removed from all } \\
\text { spaces in DOE SNF canister } \\
\text { except void in mixture }\end{array}$ & $0.90374 \pm 0.00084$ & $0.88963 \pm 0.00083$ & $0.87430 \pm 0.00082$ \\
\hline atr_pdeg_tot_all_wet-f_bss.o & $\begin{array}{l}\text { Similar to above case, but } \\
\text { waste package is completely } \\
\text { flooded }\end{array}$ & $0.89315 \pm 0.00082$ & $0.88044 \pm 0.00082$ & $0.86926 \pm 0.00088$ \\
\hline atr_pdeg_tot_3040void_bss.o & $\begin{array}{l}\text { Similar to case } \\
\text { "atr_pdeg_tot_30void" but } \\
\text { mixture in six central } \\
\text { compartments forms with } 40 \\
\text { vol\% void fraction; water in } \\
\text { DOE SNF canister only }\end{array}$ & $0.76381 \pm 0.00076$ & $0.74438 \pm 0.00082$ & $0.73034 \pm 0.00081$ \\
\hline atr_pdeg_tot_3040wet_bss.o & $\begin{array}{l}\text { Similar to above case, but } \\
\text { water fills the void in the } \\
\text { mixture }\end{array}$ & $0.94842 \pm 0.00081$ & $0.93577 \pm 0.00087$ & $0.92043 \pm 0.00078$ \\
\hline atr_pdeg_tot_fill_wet_bss.o & $\begin{array}{l}\text { Degraded mixtures are filling } \\
\text { all available space in each } \\
\text { compartment; void and spaces } \\
\text { in DOE SNF canister are } \\
\text { filled with water; the rest of } \\
\text { the waste package is dry }\end{array}$ & $0.95707 \pm 0.00080$ & $0.94303 \pm 0.00076$ & $0.93178 \pm 0.00084$ \\
\hline atr_pdeg_tot_fill_wet-f_bss.o & $\begin{array}{l}\text { Similar to above case, but } \\
\text { waste package is completely } \\
\text { flooded }\end{array}$ & $0.93369 \pm 0.00080$ & $0.91756 \pm 0.00079$ & $0.90792 \pm 0.00076$ \\
\hline atr_pdeg_tot_all_wet_bss.o & $\begin{array}{l}\text { Similar case } \\
\text { "atr_pdeg_tot_fill", wet" but } \\
\text { mixture in compartments } \\
\text { bordered by the inner sleeve } \\
\text { is allowed to fill all space } \\
\text { inside DOE SNF canister. } \\
\text { Sleeve is neglected; mixture } \\
\text { is homogenized for all these } \\
\text { compartments; waste package } \\
\text { outside DOE SNF canister is } \\
\text { dry }\end{array}$ & $0.95841 \pm 0.00085$ & $0.94533 \pm 0.00079$ & $0.93272 \pm 0.00078$ \\
\hline atr_pdeg_tot_all_wet-f_bss.o & $\begin{array}{l}\text { Similar to above case, but } \\
\text { waste package is completely } \\
\text { flooded }\end{array}$ & $0.93555 \pm 0.00081$ & $0.92205 \pm 0.00078$ & $0.90780 \pm 0.00087$ \\
\hline
\end{tabular}

The calculated k_eff decreases in every case as more boron is added to the basket material. The basket made from 304B6 comes very close to getting below the upper criticality limit of 0.93 . The thicknesses of the baskets were all assumed to be 0.375 in. in these cases, but this is not an accurate representation. Each basket will have to account for the material lost to corrosion. As the boron concentration increases in borated stainless steel, the material becomes less resistant to corrosion. Table 28 compares the corrosion rates and the thickness required for the basket that will be $0.375 \mathrm{in}$. thick after 10,000 years for 304B4 and 304B5. This table is repeated from Section 3.2. The corrosion rate of 304B6 was not cited in the study. 
Table 28. Corrosion rates for 304B4 and 304B5.

\begin{tabular}{|c|c|c|}
\hline & 304B4 & $304 B 5$ \\
\hline Corrosion rate & 80nm/yeara & 600nm/yeara \\
\hline Degraded after 10,000 years & $.08 \mathrm{~cm}$ & $.6 \mathrm{~cm}$ \\
\hline $\begin{array}{l}\text { Needed basket thickness to account for corrosion } \\
\text { and achieve a basket thickness of } 0.375 \text { inches } \\
\text { after } 10,000 \text { years }\end{array}$ & $\begin{array}{c}.44 \text { inches } \\
(1.1125 \mathrm{~cm})\end{array}$ & $\begin{array}{l}.847 \text { inches } \\
(2.1525 \mathrm{~cm})\end{array}$ \\
\hline
\end{tabular}

a $($ He 2011)

The basket thickness for 304B 4 would have to be 0.44 in. and the thickness for a basket using 304B5 would have to be 0.847 in. to ensure a thickness of 0.375 in. after 10,000 years, which was assumed in most scenarios in this evaluation. Increasing the basket thickness to $0.847 \mathrm{in}$. can be done to certain parts of the basket, but cannot be done to all of the basket as currently constructed.

\section{CONCLUSIONS}

The goal of this evaluation was to evaluate different options for a neutron absorber in the DOE Standardized SNF Canister. This was accomplished by taking the two most relevant criticality evaluations and replacing the ANA basket material with borated stainless steel.

While ANA was originally selected as the basket material for ATR fuel in the Yucca Mountain Repository License Application, it has never been produced on a large scale. Past evaluations eliminated borated stainless steel as a long-term neutron absorbing material, because it corroded too quickly and may not always remain in the waste package after degradation. This led to the invention and selection of ANA for use as the basket material in the DOE Standardized SNF Canister. After selecting ANA, new corrosion tests were performed on borated stainless steel using a different method for fabrication. This method of fabrication significantly improved the corrosion resistance properties of borated stainless steel, so much so that it out-performed ANA in limited corrosion testing. Researchers used the information obtained from these tests to select borated stainless steel as the neutron absorber in the TAD designed for commercial SNF.

This evaluation compares the criticality control of borated stainless steel to ANA. In every case and scenario, the calculated effective neutron multiplication factor (k_eff) using a borated stainless steel basket was lower than that using an ANA basket, though the borated stainless steel must be thicker due to corrosion effects over the regulatory time period. Although the borated stainless steel performed better than the ANA, it still required additional neutron-absorbing material, gadolinium shot, for the calculated k_eff to fall below the upper critical limit of 0.93 in a few cases evaluated. More research using thicker baskets or inserts could be performed in an attempt to lower the k_eff without the use of gadolinium shot. In addition, a reevaluation of the degraded ATR material used in the previous evaluations may prove that the original assumptions were over-conservative. 


\section{REFERENCES}

(ASME 2005) ASME Boiler and Pressure Vessel Code, Section III, Division 3, "Containment Systems and Transport Packaging for Spent Nuclear Fuel and High-Level Radioactive Waste," The American Society of Mechanical Engineers, New York, NY, 2002. Case N-728, Use of B-932-04 plate material for non-pressure retaining spent-fuel containment internals to 650F (343C), Section III, Division 3, May 10, 2005.

(ASTM 2004) ASTM B932-04, "Standard Specification for Low- Carbon Nickel-ChromiumMolybdenum- Gadolinium Alloy Plate, Sheet, and Strip," American Society for Testing and Materials, West Conshohocken, PA, 2004.

(BSC 2003) Bechtel SAIC Company, “Analysis of Alternative Waste Forms: Phase 2 Report,” TDRCRW-MD-000004 REV 00, DOC.20031006.0002, August 2003.

(BSC 2004) Bechtel SAIC Company, "DOE and Commercial Waste Package System Description" Document. 000-3YDDS00-00100-000-004. Las Vegas, Nevada: Bechtel SAIC Company. ACC: ENG.20040720.0009, 2004.

(Connolly 2018) M. Connolly and J. Jarrell, “Aluminum Clad Spent Nuclear Fuel Long Term Dry Storage Technical Issues Project Execution Plan,” PLN-5596, May 2018.

(CRMWS M\&O 1998) "Software Qualification Report for MCNP Version 4B2, A General Monte Carlo N-Particle Transport Code”. CSCI: 30033 V42LV. DI: 30033-2003, Ver. 01. Las Vegas, Nevada: CRWMS M\&O. ACC: MOL.19990720.0403. [DIRS 105652], 1998.

(DOE 2008) DOE, "Yucca Mountain Repository License Application,” DOE/RW-0573, Rev. 1, November 2008.

(He 2011) He et al., "Corrosion of Borated Stainless Steel in Water and Humid Air," September 2011. (Hurt 2007) Hurt, W. L., Mizia, R. E., and Clark, D. E., "Overview of a Welding Development Program for a Ni-Cr-Mo-Gd Alloy," Idaho Falls, Idaho, June 1, 2007.

(IHECSBE 2004) International Handbook of Evaluated Criticality Safety Benchmark Experiments, " 2 x 2 x11 Array of Highly Enriched Uranium with Ni-Cr-Mo-Gd Alloy, Moderated and Reflected by Polyethylene," NEA/NSC/DOC (95) 03, Organization for Economic Cooperation and Development, Nuclear Energy Agency, September 2004.

INEEL 2003. "Specification for Advanced Test Reactor Mark VII Zone Loaded Fuel Elements, IN-F-9ATR, Revision 15". SPC415, Rev. 0. Idaho Falls, Idaho: U.S. Department of Energy, Idaho National Engineering and Environmental Laboratory. ACC: DOC.20040818.0003, 2003.

(Kumar 2014) Kumar, G.R. \& Achudhan, M \& Srinivasa Rao, G., "Studies on Corrosion Behaviour of Borated Stainless Steel (304B) Welds”. 9. 7767-7772, 2014.

(Lister 2006) Lister et al., "Electrochemical Corrosion Testing of Neutron Absorber Materials," INL/EXT-06-11772, September 2006.

(Lister 2008) Lister et al., "General and Localized Corrosion of Borated Stainless Steels" NACE Corrosion 2008.

(Mizia 2004) Mizia. "Interim Report on the Corrosion Performance of a Neutron Absorbing Ni-Cr-MoGd Alloy,” DOE/SNF/REP-086, March 2004. 
(Mizia 2011) E. Mizia, Ronald and Lister, T.E, “Accelerated Testing of Neutron-Absorbing Alloys for Nuclear Criticality Control,” Nuclear Technology, Vol. 176, pp. 9-21. 10.13182/NT11-A12539, 2011.

(Morton 1999) Morton, D.K., "Preliminary Design Specification for Department of Energy Standardized Spent Nuclear Fuel Canister", National Spent Nuclear Fuel Program, DOE/SNF/REP-011, Rev. 3, Vol. I and II, August 1999.

(OCRWM 2004) OCRWM, "Intact and Degraded Mode Criticality Calculations for the Codisposal of ATR Spent Nuclear Fuel in a Waste Package," CAL-DSD-NU-000007 Rev. 00A, DOC.20041018.0001 2004.

(Paige 1969) Paige, B.E.. "Description of Test Reactor Fuel Elements and Associated Behavior in Reprocessing". CI-1152. Idaho Falls, Idaho: U.S. Atomic Energy Commission, Idaho Operations Office. ACC: MOL.20040303.0031, 1969.

(Petersen 2019a) G. Petersen, S. Birk, K. Bulmahn, B. Carlsen, D. Daubaras, L. Montierth, R. Smith, "History and Status of DOE's Standardized Canister", Proc. WM2019, Phoenix, AZ, March 2019.

(Petersen 2019b) G. Petersen, B. Carlsen, J. Jarrell, "Neutron Absorber Considerations for the DOE Standardized Canister”, Proc. ANS IHLRWM 2019, Knoxville, TN, April 2019.

(Reed 1992) Reed, J.D.; Wages, L.V.; Vinnola, A.J., Jr.; Fillmore, G.N.; and Anderson, E.C., Sr. "Specification for Reactor Grade High Enriched Uranium Aluminide (UAlx) Powder". IN-F-5-TRA, Rev. 9. Idaho Falls, Idaho: EG\&G Idaho Inc. TIC: 256484, 1992.

(Taylor 2004) Taylor. "Packaging Strategies for Criticality Safety for 'Other' DOE Fuels in a Repository,” DOE/SNF/REP-090, June 2004.

(Wachs 2007) Wachs, Gregg W., "Characterization of an Advanced Gadolinium Neutron Absorber Alloy By Means Of Neutron Transmission,” Idaho Falls, Idaho, September 1, 2007.

(Werner 2018) C.J. Werner, J.S. Bull, C.J. Solomon, et al., "MCNP6.2 Release Notes," LA-UR-1820808, 2018. 